\title{
Ontwikkeling van enkele mosselbanken in de Nederlandse Waddenzee, situatie 2016
}



Ontwikkeling van enkele mosselbanken in de Nederlandse Waddenzee, situatie 2016 
Dit Technical report is gemaakt conform het Kwaliteitsmanagementsysteem (KMS) van de unit Wettelijke Onderzoekstaken Natuur \& Milieu, onderdeel van Wageningen University \& Research.

De WOT Natuur \& Milieu voert wettelijke onderzoekstaken uit op het beleidsterrein natuur en milieu. Deze taken worden uitgevoerd om een wettelijke verantwoordelijkheid van de minister van Landbouw, Natuur en Voedselkwaliteit te ondersteunen. De WOT Natuur \& Milieu werkt aan producten van het Planbureau voor de Leefomgeving, zoals de Balans van de Leefomgeving en de Natuurverkenning. Verder brengen we voor het ministerie van Economische Zaken adviezen uit over (toelating van) meststoffen en bestrijdingsmiddelen, en zorgen we voor informatie voor Europese rapportageverplichtingen over biodiversiteit.

De reeks 'WOt-technical reports' bevat onderzoeksresultaten van projecten die kennisorganisaties voor de unit Wettelijke Onderzoekstaken Natuur \& Milieu hebben uitgevoerd.

WOt-technical report 105 is het resultaat van een onderzoeksopdracht van en gefinancierd door het Ministerie van Landbouw, Natuur en Voedselkwaliteit (LNV). 


\section{Ontwikkeling van enkele mosselbanken in de Nederlandse Waddenzee, situatie 2016}

S.T. Glorius, A. Meijboom, J.T. van der Wal \& J.S.M. Cremer 


\section{Referaat}

Glorius, S.T., A. Meijboom, J.T. van der Wal \& J.S.M. Cremer (2017). Ontwikkeling van enkele mosselbanken in de Nederlandse Waddenzee, situatie 2016. Wageningen, Wettelijke Onderzoekstaken Natuur \& Milieu, WUR. WOt-technical report 105/ WMR-rapport C164/15. 54 blz.; 15 fig.; 2 tab.; 38 ref; 2 Bijlagen.

Wageningen Marine Research bestudeert de ontwikkeling op de lange termijn van een aantal individuele droogvallende mosselbanken in de Nederlandse Waddenzee met speciale aandacht voor de eigenschappen die het al dan niet overleven van mosselbanken bepalen. Het onderzoek wordt uitgevoerd in het WOT-thema Informatievoorziening Natuur. Het blijkt dat de mosselbanken in het algemeen na het jaar van ontstaan langzaam in oppervlakte, bedekkingspercentage en populatiedichtheid achteruitgaan en dat het aandeel lege schelpen, algen, en zeepokken toeneemt. De afname in oppervlakte en bedekking wordt af en toe tenietgedaan door een goede broedval, waarna het proces opnieuw begint en een mosselbank met meer jaarklassen ontstaat. Introductie van Japanse oesters in bestaande mosselbanken blijkt een algemeen verschijnsel wat resulteert in een hoger bedekkingspercentage en een afname in de mosselbiomassa. Na een grote broedval van de Japanse oester in 2014 en succesvolle ontwikkeling van deze oesters in 2015 en 2016 op twee banken gelegen nabij het eiland Rottum is het aandeel oesters in de schelpdierbiomassa op deze banken flink toegenomen.

Trefwoorden: droogvallende mosselbank, litorale mosselbank, mosselen, Japanse oesters, Waddenzee

\section{Abstract}

Glorius, S.T., A. Meijboom, J.T. van der Wal \& J.S.M. Cremer (2017). Development of mussel beds in the Dutch Wadden Sea: situation in 2016. Wageningen, the Statutory Research Tasks Unit for Nature \& the Environment (WOT Natuur \& Milieu)/ Wageningen Marine Research. WOt-technical report 105/ WMR-rapport C164/15. 54 p.; 34 Figs; 2 Tabs; 39 Refs; 3 Annexes.

Wageningen Marine Research is studying the long-term development of a number of individual mussel beds in the Dutch part of the Wadden Sea to identify the characteristics that determine the survival of such beds. The study is being carried out as part of the WOT theme 'Nature Information Infrastructure'. The results so far show that the mussel beds tend to gradually decrease in size, coverage and population density after the year in which they come into existence. The proportion of empty shells, algae and barnacles increases. The decline in size and coverage of mussel beds is occasionally interrupted by new mussel spatfall, after which the process starts again. Over the years, a mussel bed with multiple year classes and a diverse community gradually develops. Japanese oysters have settled in all beds, leading to large shifts in the mussel population. A good oyster spatfall in 2014 in two mussel beds located near the island Rottum and successful oyster growth in subsequent years has resulted in a large increase in oyster biomass in these beds.

Key words: littoral mussel beds, Japanese Oyster, Wadden Sea

\section{(C) 2017 Wageningen Marine Research}

Postbus 57, 1780 AB Den Helder

Tel: (0317) 480 900; e-mail: secretariaat.marine-research@wur.nl

De reeks WOt-technical reports is een uitgave van de unit Wettelijke Onderzoekstaken Natuur \& Milieu, onderdeel van Wageningen University \& Research. Dit technical report is verkrijgbaar bij het secretariaat. De publicatie is ook te downloaden via www.wur.nl/wotnatuurenmilieu.

Wettelijke Onderzoekstaken Natuur \& Milieu, Postbus 47, 6700 AA Wageningen

Tel: (0317) 4854 71; e-mail: info.wnm@wur.nl; Internet: www.wur.nl/wotnatuurenmilieu.

Alle rechten voorbehouden. Niets uit deze uitgave mag worden verveelvoudigd en/of openbaar gemaakt door middel van druk, fotokopie, microfilm of op welke andere wijze ook zonder voorafgaande schriftelijke toestemming van de uitgever. De uitgever aanvaardt geen aansprakelijkheid voor eventuele schade voortvloeiend uit het gebruik van de resultaten van dit onderzoek of de toepassing van de adviezen. 


\section{Woord vooraf}

In deze jaarlijkse werkrapportage wordt de ontwikkeling van enkele individuele mosselbanken beschreven. Elk jaar wordt de informatie aangevuld met de gegevens van het afgelopen jaar. Dit rapport beschrijft de situatie tot en met 2016. Aan de hand van de ontwikkelingen van de mosselbanken samen wordt een algemeen beeld geschetst van de ontwikkeling van mosselbanken over de jaren. Het project 'Ontwikkeling mosselbanken' is uitgevoerd in het kader van de wettelijke onderzoekstaken binnen het thema Informatievoorziening Natuur, gecoördineerd door het ministerie van Landbouw, Natuur en Voedselkwaliteit (LNV). De inventarisaties worden ingebracht in het Trilaterale Monitoring Programma zoals dat internationaal is overeengekomen voor de Waddenzee (TMAP) en onder andere gebruikt in rapportages over de toestand van de natuur in het Natura 2000gebied Waddenzee. Dit onderzoek zou niet mogelijk zijn zonder de hulp en inzet van de bemanning van de schepen van de Waddenunit van het ministerie van LNV.

Sander Glorius, André Meijboom, Jan Tjalling van der Wal \& Jenny Cremer 



\section{Inhoud}

$\begin{array}{lr}\text { Woord vooraf } & 5\end{array}$

$\begin{array}{lr}\text { Samenvatting } & 9\end{array}$

$\begin{array}{lr}\text { Summary } & 11\end{array}$

$1 \quad$ Inleiding $r$

1.1 Mosselbanken $\quad 13$

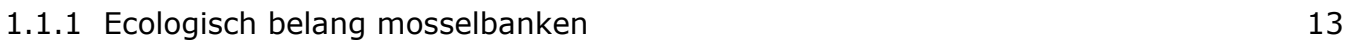

1.1.2 Aanwezigheid en ontwikkeling mosselbanken in het verleden 13

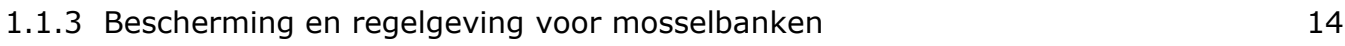

1.1.4 Huidige ontwikkeling biomassa en oppervlakte mosselbanken $\quad 14$

1.2 Doel en aanpak van het onderzoek $\quad 14$

2 Methoden $\quad 17$

$\begin{array}{lll}2.1 & \text { Locatie mosselbanken } & 17\end{array}$

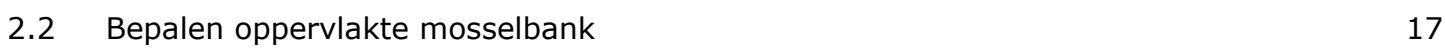

$\begin{array}{llr}2.3 & \text { Bedekkingsmeting } & 18\end{array}$

2.3.1 Raaien en subraaien $\quad 18$

2.3.2 Verdeling van de raaien $\quad 19$

2.3.3 Score van de mosselbedekking langs de raaien $\quad 19$

$\begin{array}{ll}2.4 & \text { Lengte-frequentieverdeling en samenstelling } \\ \end{array}$

$\begin{array}{llr}3 & \text { Resultaten } & \mathbf{2 1}\end{array}$

$\begin{array}{lll}3.1 & \text { Ontwikkeling contouren en oppervlakte } & 21\end{array}$

$\begin{array}{lll}3.2 & \text { Ontwikkeling mosselabundantie } & 26\end{array}$

$\begin{array}{lll}3.3 & \text { Oesterontwikkeling } & 28\end{array}$

$\begin{array}{lll}3.4 & \text { Samenstelling leefgemeenschap op de mosselbanken } & 30\end{array}$

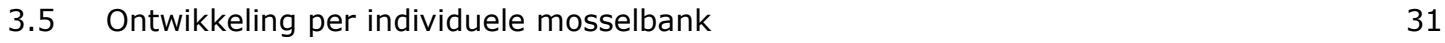

3.5.1 Bank 101 - Balgzand 31

3.5.2 Bank 502 - Ameland Molengatplaat $\quad 31$

3.5.3 Bank 503 - Ameland Ballumerbocht $\quad 32$

3.5.4 Bank 603 - Schiermonnikoog Brakzand $\quad 32$

3.5.5 Bank 606 - Zuid Oost Lauwers Noord 32

3.5.6 Bank 607 - Zuid Oost Lauwers Zuid 32

3.5.7 Bank 703 - Rottum Wantij 33

3.5.8 Bank 710 - Rottumerplaat 33

3.5.9 Bank 726 - Rottumerplaat Schild

3.5.10Bank 734 - Rottumeroog Zuiderduintjes $\quad 34$

3.5.11Bank 735 - Rottumeroog $\quad 34$

3.5.12Bank 736 - Rottumeroog Oost

$4 \quad$ Discussie en conclusie $\quad 35$

$\begin{array}{lr}\text { Literatuur } & \mathbf{3 7}\end{array}$

$\begin{array}{ll}\text { Verantwoording } & 39\end{array}$

$\begin{array}{lll}\text { Bijlage } 1 \quad \text { Monsterpunten } & 41\end{array}$

Bijlage 2 Bedekking mosselbanken $\quad 45$

Bijlage 3 Oesterbedekking mosselbanken 49 



\section{Samenvatting}

\section{Achtergrond en werkwijze}

Mosselbanken worden algemeen gezien als een belangrijke ecotoop binnen de Waddenzee. In het beheerplan van de Waddenzee voor de periode 2016-2022 (Min. I\&M, 2016) is opgenomen dat herstel van droogvallende mosselbanken en zeegrasvelden noodzakelijk is om de kwaliteit van habitattype H1140 'droogvallende zandplaten' te verbeteren. Daarnaast is in het beheerplan geconstateerd dat het herstel van litorale mosselbanken met name in de oostelijke Waddenzee achterblijft ten opzichte van de westelijke Waddenzee. Na het verdwijnen van de droogvallende mosselbanken in de jaren negentig van de vorige eeuw werd door sommigen betwijfeld of mosselbanken wel meerdere jaren konden blijven bestaan. Daarom wordt binnen dit project elk jaar een aantal individuele mosselbanken op de droogvallende platen gekarteerd om de locatie en omvang op dat moment vast te stellen, alsmede jaarlijkse veranderingen hierin te kunnen documenteren.

Om geobserveerde veranderingen beter te kunnen verklaren, wordt naast het karteren van ieder van de onderzochte mosselbanken ook informatie verzameld over de samenstelling van de bank. Zo worden onder andere bepaald: het bedekkingspercentage per mosselbank, de grootteklasseverdeling en biomassa van de mosselen, het percentage oesters en andere organismen op de mosselbank. In het voorjaar van 2016 werden de mosselbanken 502 (Ameland Molengatplaat), 503 (Ameland Ballumerbocht), 603 (Schiermonnikoog), 606 (Zuid Oost Lauwers Noord) en 607 (Zuid Oost Lauwers Zuid) bezocht. In het najaar werden de banken 703 (Rottum Wantij), 710 (Rottumerplaat) en 736 (Rottumeroog-Oost) bezocht. Aan de hand van de veranderingen van de individuele mosselbanken, wordt een algemeen beeld geschetst van de ontwikkeling van mosselbanken over de jaren tot en met 2016. Het onderzoek wordt uitgevoerd in het kader van wettelijke onderzoekstaken thema Informatievoorziening Natuur, gecoördineerd door het ministerie van Landbouw, Natuur en Voedselkwaliteit (LNV).

\section{Resultaten}

Een groot deel van de hier onderzochte banken (502, 503, 603, 703, 710 en 736) blijken erg stabiel te zijn. Ze hebben zich, door onder andere periodiek terugkomende mosselbroedvallen, sinds de start van het onderzoek kunnen handhaven (een opvallend goede broedval is in 2015 geconstateerd) en zijn reeds tussen de 12 en 23 jaar aanwezig op min of meer dezelfde plek. Ook de randen van de banken blijken, voor grote delen van de mosselbank, opvallend stabiel te zijn. Er blijken echter ook meer dynamische bankdelen te zijn die zich uitbreiden door verschuivingen na storm(en) en/of na een goede zaadval en bankdelen die weer uiteenvallen onder invloed van dezelfde stormen en predatie door onder meer vogels. Door verschillen in bankstructuur, lokale verschillen in zaadval, storminvloeden en predatiedruk is langjarige bankoverleving niet vanzelfsprekend. Zo zijn de afgelopen periode een aantal banken - opgenomen in dit onderzoek (606, 726 en 735) - verdwenen nadat deze ongeveer 5 tot 10 jaar aanwezig waren.

De introductie van de Japanse oester heeft grote invloed gehad op de mosselpopulatie en Japanse oesters worden inmiddels op alle banken aangetroffen. Qua aantallen zijn mosselen nog altijd in de meerderheid maar qua biomassa is dit voor bijvoorbeeld 502 en 503 al jaren niet meer zo. Er heeft een opvallend goede oesterbroedval plaatsgevonden in 2014 op de banken 603, 710 en 736 . Door oestergroei in de jaren erop is het aandeel Japanse oester in de biomassa schelpdieren op die banken de laatste jaren sterk toegenomen en heeft het de schelpdierbiomassa gedomineerd in de afgelopen twee jaar in de banken 710 en 736 . Het is momenteel niet duidelijk of het effect van oesters op de mosselpopulatie uitgewerkt is.

Zoals ook in de eerdere tussenrapportages (o.a. Fey et al., 2014) is geconcludeerd, gaan de mosselbanken in het algemeen na het jaar van ontstaan langzaam in oppervlakte, bedekkingspercentage en populatiedichtheid achteruit. Op de mosselbanken neemt dan het percentage lege schelpen, algen, zeepokken en restgewicht toe in verhouding tot de levende mosselen. De afname in 
oppervlakte en bedekking wordt af en toe onderbroken door een goede broedval, waarna het proces opnieuw begint. Over de jaren ontstaat dus geleidelijk een mosselbank met meer jaarklassen en met een gevarieerde gemeenschap. Ondanks de overeenkomsten in algemene ontwikkeling, zijn er jaarlijks grote verschillen te zien in de ontwikkeling tussen individuele mosselbanken. Deze verschillen kunnen ontstaan door locatie (en dus blootstellingen aan storm of predatie) of door karakteristieken van de mosselbank (de mate waarin deze bestand is tegen stormen en predatie). 


\section{Summary}

\section{Background and working method}

Mussel beds are generally regarded as an important ecotope in the Wadden Sea. In the management plan for the Wadden Sea for the period 2016-2022, the Ministry of Infrastructure and Environment (2016) stresses the need for a recovery of the areal coverage of littoral mussel beds and eelgrass beds in order to improve the quality targets set for habitat type H1140. After the disappearance of the beds in the 1990s, it was doubted by some whether mussel beds can actually exist for several years. Hence, the present project involved mapping a number of individual mussel beds in order to document their current location and size and the changes in these parameters over the years. In addition to these basic assessments, we also collected data on the characteristics of the mussel beds that were being surveyed, including the coverage of individual beds, the size classes and biomass of the mussels, and the percentages of oysters and other organisms in the beds.

In spring 2016 the following mussel beds were visited and mapped; 502 (Ameland Molengatplaat), 503 (Ameland Ballumerbocht), 603 (Schiermonnikoog), 606 (Zuid Oost Lauwers Noord) and 607 (Zuid Oost Lauwers Zuid). In autumn of the same year the mussel beds 703 (Rottum Wantij), 710 (Rottumerplaat) and 736 (Rottumeroog-Oost) were recorded. The changes in all surveyed beds was combined to obtain an overall picture of the development of the mussel beds over the years. This research is carried out as part of the statutory research tasks under theme 'Nature Information Infrastructure'.

\section{Results}

The results show that most of the mussel surveyed beds are very stable (beds 503, 503, 703,710 and 736). Supported by periodically occurring mussel spatfall, these beds have been present for 12 to 23 years without interruption (in most beds there was a particularly good spatfall in 2015). The boundaries of most of these mussel beds are relative stable as well, although some parts of the mussel beds are more dynamic, either expanding due to rearrangement by storms of parts of the mussel bed and/or due to local spatfall, or disappearing due to the same storms and/or predation by birds and crabs. Differences in bed structure and spatial differences in mussel spatfall, storm events and predation pressure make long-term mussel bed survival far from certain. Several mussel beds $(606,726$ and 735) have disappeared in recent years after being present for about 5 to 10 years.

Currently Japanese oysters are present in all beds and exert a big influence on the mussel population. Numerically, mussels are still the dominant shellfish species in all beds, but oysters have dominated the shellfish biomass in beds 502 and 503 for many years. A markedly good oyster spatfall in beds 603, 710 and 736 in 2014 and high oyster survival and growth rates in subsequent years has resulted in a large increase of oyster biomass in those beds.

As already described in previous reports (e.g. Fey et al., 2014) the mussel beds tend to gradually decline in size, coverage and population density after the year in which the bed arises. This means that the coverage of empty shells, algae, barnacles and other biomass increases relative to that of the living mussels. The decline in size and coverage is occasionally interrupted by new mussel spat deposition, after which the process is repeated. Over the years, a mussel bed with multiple year classes and a diverse community gradually develops. Japanese oysters have settled in all beds, leading in most cases to large shifts in the mussel population. It is not clear whether or not this effect has fully run its course or not. Despite the similarities in the general pattern of development, individual mussel beds show major differences in development each year, which may result from the characteristics of the location (e.g. exposure to gales or predators) or of the mussel bed itself (e.g. whether it is vulnerable to gales and predation). 



\section{$1 \quad$ Inleiding}

\subsection{Mosselbanken}

\subsubsection{Ecologisch belang mosselbanken}

Mosselbanken vormen een belangrijk landschappelijk element in de Waddenzee. De mosselbulten van een mosselbank kunnen meer dan een meter hoog worden en zijn in het verder vlakke landschap al van verre te zien. Tussen de mosselbulten ontstaan plassen en prieltjes, die soms meer dan 1,5 meter diep kunnen worden. Wanneer bij eb het zeewater zakt, verschijnen de bulten als eerste boven water. Het water stroomt via de prieltjes van de bank, waardoor snel stromende beekjes ontstaan. Zelfs als de mosselen door bijvoorbeeld storm van een mosselbank zijn verdwenen, blijven de ontstane structuren als kleibulten en schelplagen nog jaren zichtbaar en vormen een geschikte vestigingsplaats voor nieuw mosselbroed.

De individuele mosselen in de bank vormen een belangrijke schakel tussen de ecosystemen van het open water en de bodemzone daaronder (Dame, 2011, Prins et al., 2005). Ze filteren slib en organisch materiaal uit het water en leggen dat vast (Prins et al., 1996). Hiermee verhogen zij de lokale productie (Asmus, 1991; Dame et al., 1991; Petersen et al., 2012). Daarnaast vormen zij door de stabiele structuur een hard substraat in een verder 'zachte' omgeving. Door deze eigenschappen bieden mosselbanken structuur en leefruimte aan andere soorten (Nehls et al., 1997; Gutiérrez et al, 2003; Buschbaum et al., 2009). Op de mosselen zelf groeien zeeanemonen en andere soorten die graag op hard substraat voorkomen. Tussen de mosselen vinden soorten als de alikruik een geschikte leefomgeving en in de poeltjes tussen de mosselbulten zwemmen vissen als grondels en botten en andere bodemdieren als garnalen.

Mosselbanken vormen 'hotspots' in de omgeving; de biodiversiteit binnen de mosselbank is hoger dan in het aangrenzende zandige wad (Günther, 1996; Markert et al., 2010; Buschbaum et al., 2009; Kochmann et al., 2008). Zowel het aantal soorten als diversiteit zijn afhankelijk van de leeftijd en complexiteit van de mosselbank (Tsuchiya \& Nishihira, 1985; Tsuchiya \& Nishihira, 1986). De mosselen op de mosselbank en de andere aan mosselbanken geassocieerde soorten vormen een voedselbron voor vogels en grote vissen. In de jaren tachtig van de vorige eeuw telde Zwarts (1991) $25 \%$ van alle wadvogels op de mosselbanken die toen $3 \%$ van het droogvallende wad innamen. Ook Ens (1996) vond een positieve correlatie tussen vogeldichtheden en mosselbanken.

\subsubsection{Aanwezigheid en ontwikkeling mosselbanken in het verleden}

Mosselbanken kwamen in het verleden naar alle waarschijnlijkheid veel voor. De banken kenmerken zich door een grote mate van plaatsvastheid, waardoor duidelijke 'mosselgebieden' aan te wijzen zijn (Dankers et al., 2003, 2006; Dankers \& Fey, 2015). De eerste kwantitatieve schatting - gebaseerd op luchtfoto-interpretatie - van de volledige Waddenzee werd gemaakt door Dijkema et al. (1989). Zijn kaart, gebaseerd op de situatie eind jaren zeventig, geeft een areaal van 4152 ha of \pm 4200 ha (Dankers et al., 1989; Tydeman, 1996). Retrospectief onderzoek in het kader van EVA II (Evaluatie Schelpdiervisserijbeleid) komt uit op uiterste grenzen tussen 1000 en 6000 hectare (Dankers et al., 2003).

In de jaren tachtig nam het areaal mosselbanken af door intensieve visserij en strenge winters. In het voorjaar van 1987 was nog slechts 650 ha over, maar op oude banken ontwikkelden zich nieuwe banken die in de jaren 1988-1990 opnieuw werden weggevist. Tussen 1991 en 1994 was minder dan 200 ha over (Dankers et al., 2003). Veel banken die daarna in de jaren negentig ontstonden waren niet stabiel genoeg om winterstormen en ijsschade te overleven (Dankers et al., 2004), maar geleidelijk nam het areaal weer toe. 


\subsubsection{Bescherming en regelgeving voor mosselbanken}

In het beheerplan van de Waddenzee voor de periode 2016-2022 (Min. I\&M, 2016) is opgenomen dat herstel van droogvallende mosselbanken en zeegrasvelden noodzakelijk is om de kwaliteit van habitattype H1140 'droogvallende zandplaten' te verbeteren. Om dit doel voor mosselbanken te bereiken, zijn gebieden gesloten voor mosselzaadvisserij en wordt mosselzaadvisserij op de overige wadplaten slechts toegestaan op jonge en instabiele mosselbanken onder zeer strikte voorwaarden waaronder de aanwezigheid van minimaal 2000 ha meerjarige litorale mosselbanken (LNV, 1994 \& 2004). Na 1994 is er alleen in 2001 nog op enkele mosselbanken op het droogvallende wad gevist (voor onderzoek).

Mosselbanken vormen een belangrijk onderdeel van habitattype $\mathrm{H} 1140$ 'bij eb droogvallende slikwadden en zandplaten' binnen de Natuurbeschermingswet (Natura 2000). Daarnaast zijn binnen deze wet instandhoudingsdoelstellingen opgesteld voor verschillende vogelsoorten voor wie schelpdieren een belangrijke voedselbron vormen. Mosselen en mosselbanken zijn hiermee wettelijk beschermd als belangrijke componenten in het ecosysteem.

\subsubsection{Huidige ontwikkeling biomassa en oppervlakte mosselbanken}

In opdracht van het ministerie van Landbouw, Natuur en Voedselkwaliteit (LNV) binnen de wettelijke onderzoekstaken op het gebied van visserij, schat Wageningen Marine Research jaarlijks het totale areaal aan droogvallende mossel- en Japanse oesterbanken, alsmede de totale biomassa in deze banken (Van den Ende et al., 2016). Uit deze inventarisatie is gebleken dat in het voorjaar van 2016 het areaal aan mossel- en mossel/oesterbanken net iets boven de 2000 ha ligt, namelijk 2052 ha (Van den Ende et al., 2016; Figuur 1.1). Het areaal is hierbij met ruim 300 ha toegenomen ten opzichte van het voorgaande jaar toen er 1739 ha lag. In 2016 werd er 131 ha aan nieuwe mosselzaadbanken gekarteerd wat meer is dan in voorgaande jaren (2015 werd 9 en in 201480 ha gekarteerd). De nieuwe mosselzaadbanken in 2016 werden gevonden aan de oostkant van Balgzand, rondom de Oude Zuidmeep, de Ballumerbocht, Smeriggat en het Friesche Wad (Van den Ende et al., 2016).

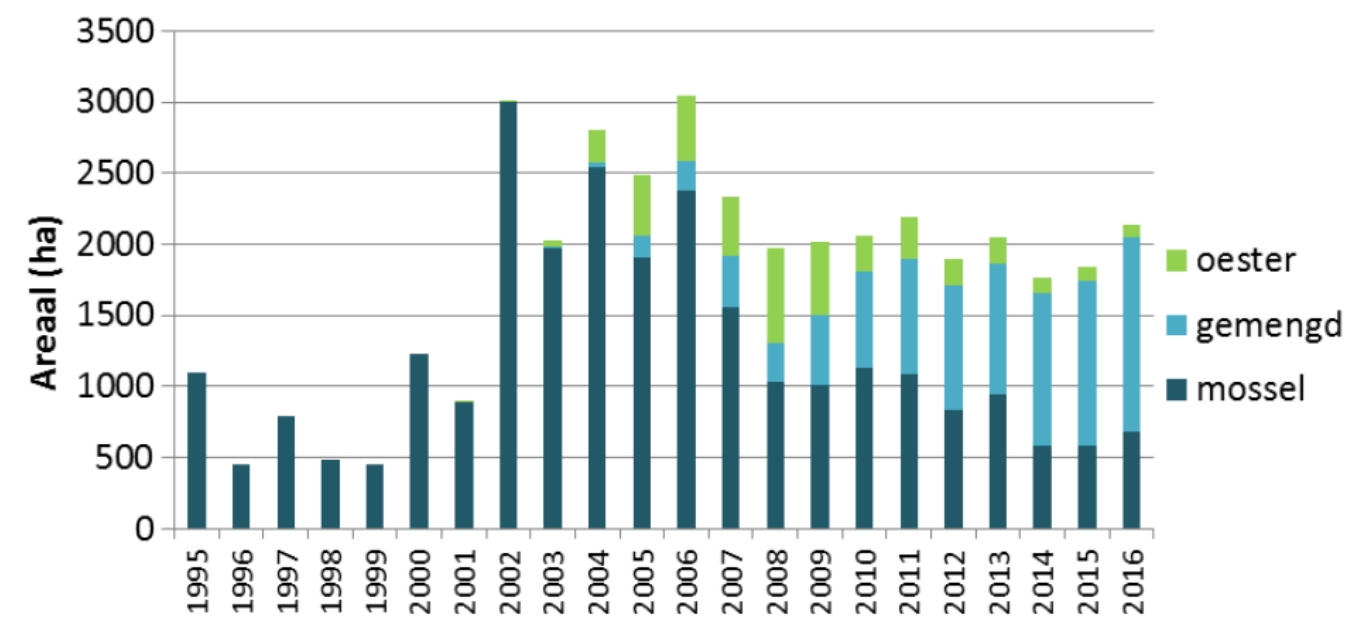

Figuur 1.1 Areaal mosselbanken in het droogvallende deel van de Nederlandse Waddenzee (Van den Ende et al., 2016).

\subsection{Doel en aanpak van het onderzoek}

\section{Doel}

Aanwezigheid van voldoende vitale litorale mosselbanken is kenmerkend voor de structuur en functie van het Natura 2000-habitattype. Daarnaast kan, wanneer het totale oppervlakte aan droogvallende meerjarige mosselbanken boven een areaal van 2000 ha komt, onder strenge voorwaarden een vergunning aangevraagd worden om hierop te vissen. Voor zowel de vergunningverlening als het herstel van litorale mosselbanken is het essentieel om inzicht te hebben in de factoren die overleving 
van mosselbanken bepalen, en inzicht in hoe mosselbanken zich na ontstaan ontwikkelen. Ook is in trilateraal kader (TMAP) besproken dat in alle Waddenlanden een aantal mosselbanken in detail bestudeerd kan worden, naast de jaarlijkse globale inventarisaties die inzicht geven in het totaaloppervlak en biomassa (o.a. Van den Ende et al., 2016).

Het doel van het project is het ter beschikking krijgen van gedetailleerde informatie over de toestand en langjarige ontwikkeling van een aantal geselecteerde mosselbanken in de Waddenzee. De onderzoeksvraag is: Hoe ontwikkelen individuele mosselbanken zich wat betreft oppervlakte, bedekkingspercentage, lengtefrequentieverdeling en samenstelling over de lange termijn?

Het project 'Ontwikkeling mosselbanken' werd de eerste jaren uitgevoerd in opdracht van de LNV Directie Wetenschap en Kennisoverdracht (DWK), maar vanaf 2006 wordt het uitgevoerd in het kader van wettelijke onderzoekstaken thema Informatievoorziening Natuur, gecoördineerd door het ministerie van Economische Zaken (vanaf eind 2017 wederom door LNV). De inventarisaties worden ingebracht in het trilaterale monitoring programma (TMAP) en onder andere gebruikt in rapportages over de toestand van de natuur in het Natura 2000-gebied Waddenzee.

\section{Aanpak}

Om de langetermijnontwikkeling van mosselbanken te bestuderen, wordt een aantal mosselbanken gekarteerd om de locatie en omvang op dat moment vast te stellen, alsmede jaarlijkse veranderingen hierin te kunnen documenteren. Om geobserveerde veranderingen beter te kunnen verklaren, wordt naast het karteren van ieder van de onderzochte mosselbanken ook informatie verzameld over de samenstelling van de bank. Zo worden onder andere bepaald: het bedekkingspercentage per mosselbank, de grootteklasseverdeling en biomassa van de mosselen, het percentage oesters en andere organismen op de mosselbank.

Binnen dit project worden zes mosselbanken, gelegen in oostelijke Waddenzee, gevolgd. Éen bank is sinds 1995 jaarlijks bezocht, één sinds 1997, één sinds 1998 en drie sinds 2002. Deze banken worden in het voorjaar bezocht en hebben dus te maken gehad met wintersterfte van dat jaar, maar nog niet met eventuele nieuwe broedval. Daarnaast wordt in dit rapport de ontwikkeling van vijf andere mosselbanken beschreven die gevolgd worden voor een ander project, TMAP-Rottum. In aansluiting met het bemonsteringsmoment van het TMAP Rottum-programma worden deze banken niet in het voorjaar maar in het najaar bemonsterd en kunnen daarom al te maken hebben gehad met broedval uit hetzelfde jaar. Deze banken zijn sinds 2006 jaarlijks bezocht. 



\section{$2 \quad$ Methoden}

\section{$2.1 \quad$ Locatie mosselbanken}

In mei 2016 werden mosselbank 502, 503, 603, 606, 607 en 703 onderzocht. In oktober 2016 werden mosselbank 710 en 736 onderzocht in het kader van het project TMAP-Rottum. Mosselbanken 101, 726, 734 en 735 werden niet meer bezocht; mosselbank 101 in verband met het gekrompen budget en 726,734 en 735 omdat ze in de voorgaande jaren zijn verdwenen (Figuur 2.1).

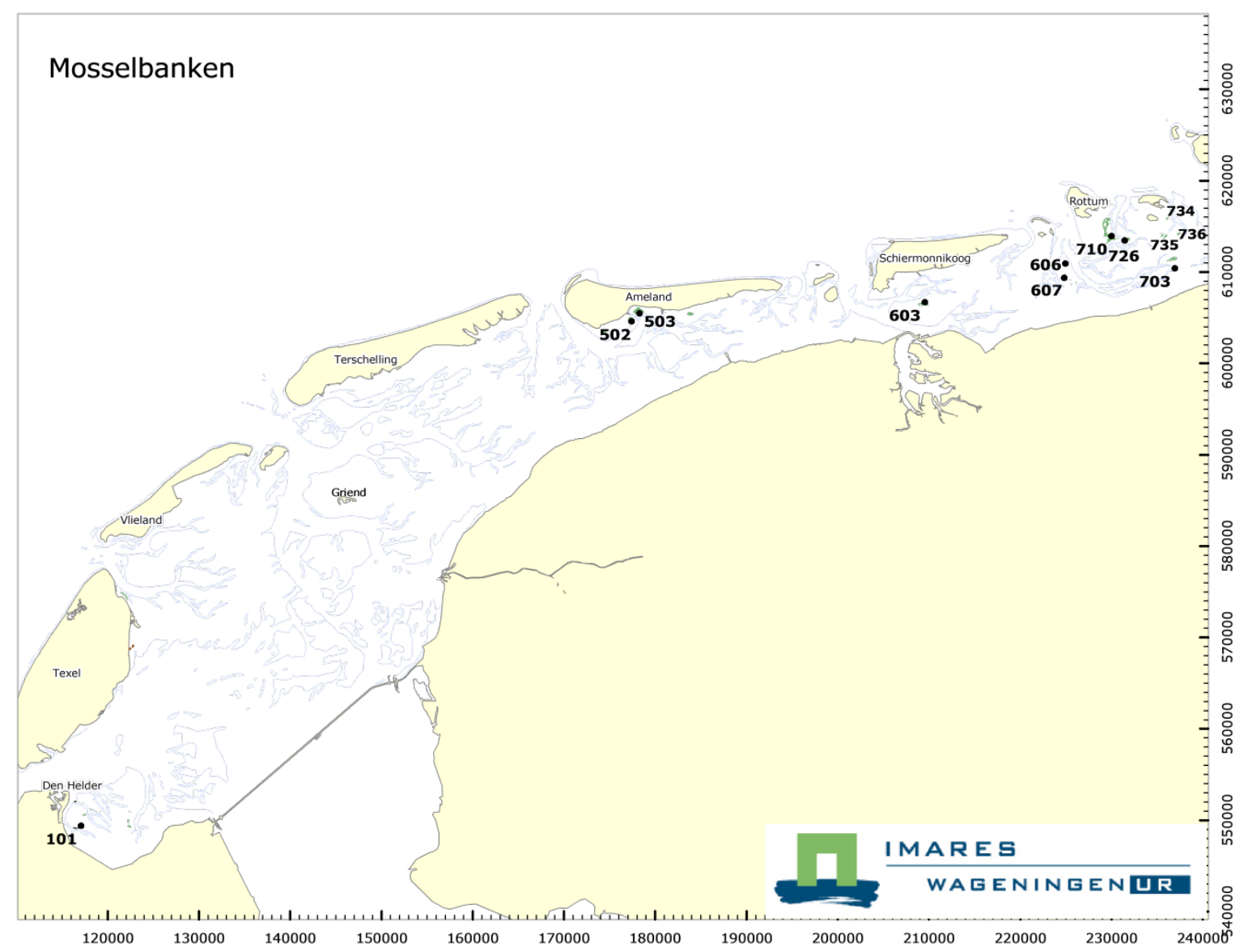

Figuur 2.1. Locatie mosselbanken 101, 502, 503, 603, 606, 607, 703, 710, 726, 734, 735 en 736.

\subsection{Bepalen oppervlakte mosselbank}

De buitenste contour van de mosselbank worden volgens het TMAP-protocol (Brinkman et al., 2003), zie Figuur 2.2., in kaart gebracht. Hiervoor wordt met een GPS in de hand langs de rand van de bank om de bank heen gelopen waarbij de gelopen track opgeslagen in GPS-files. Er is gebruik gemaakt van Garmin GPS; 76, map76cx of 78. Alleen wanneer de bodem voor $>5 \%$ met mosselbulten bedekt wordt, is deze bij de bank gerekend. Mosselbulten die verder dan 25 meter van de hoofdbank liggen worden niet bij de bank gerekend. Zie voor details Figuur 2.2 en Brinkman et al., (2003).

De GPS-files zijn in ARC-INFO GIS opgeslagen. In ArcGis is aan de hand van de mosselbankcontour het bankoppervlak bepaald. De ontwikkeling van de mosselbanken over de jaren wordt bekeken door de contouren van verschillende jaren van dezelfde bank in één figuur weer te geven. 


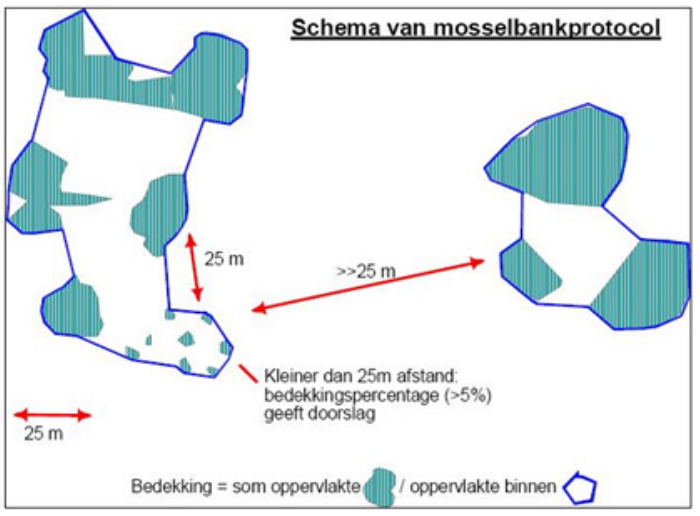

Loop langs de rand van een mosselbank, en registreer (voortdurend) de positie. De rand van de bank wordt bepaald aan de hand van drie regels:

a) Ga na of er sprake is van waarneembare structuren zoals verwoord in de definitie (dus bulten of patches, geen strooimosselen)

b) de 25 meter regel

Loop in geval van een min of meer gesloten bank langs de rand van de bank. Bij inhammen mag je oversteken naar de dichtstbijzijnde rand op $25 \mathrm{~m}$ afstand

De afzonderlijke mosselbulten van een mosselbank mogen niet verder dan 25

meter uit elkaar liggen. Is bij grote bulten de afstand tussen tot de

volgende bult of bultenverzameling meer dan $25 \mathrm{~m}$, dan betreft het een andere bank. (zie figuur als voorbeeld)

c) de $5 \%$ regel

Minimaal moet ongeveer $5 \%$ van de bodem bedekt zijn met mosselbulten of patches. Dat wil zeggen dat de afstand tussen de bulten niet meer dan ongeveer 3.5 maal zo groot mag zijn dan de diameter van de bulten. Nog kleinere bedekkingen kunnen in de rand van een mosselbank voorkomen, maar worden niet meer bij de mosselbank gerekend.

Figuur 2.2 TMAP protocol voor het inlopen van mosselbanken (Brinkman et al., 2003).

\subsection{Bedekkingsmeting}

Om de mosselbedekking te bepalen, worden over de mosselbank raaien gelopen waarlangs de met mosselen bedekte oppervlak bepaald wordt. Hiervoor wordt voor iedere raai (en subraai, zie par. 2.3.1) zowel het totaalaantal, als het aantal stappen dat op mosselen gezet is geteld en genoteerd. In de volgende paragrafen wordt de gevolgde procedure in detail beschreven.

\subsubsection{Raaien en subraaien}

De raai loopt van de rand van de mosselbank in een rechte lijn tot de tegenoverliggende rand van de mosselbank. Bij voorkeur wordt gebruik gemaakt van de in dat jaar en volgens het TMAP-protocol ingelopen contour van de bank. Wanneer deze nog niet aanwezig is wordt de rand van de bank ter plekke bepaald op basis van het TMAP-protocol. Binnen deze raai worden subraaien genoteerd van elk 50 stappen om zodoende een meer gedetailleerd beeld van de bedekking te verkrijgen. Bij het startpunt en aan het eind van elke subraai wordt in de GPS een waypoint (lokatiemarkering) gemaakt. Bij het eindpunt van de raai (dus de rand van de mosselbank) wordt altijd een waypoint gemaakt, ook al zijn de 50 stappen nog niet voltooid. In dat geval wordt het werkelijk aantal gemaakte stappen genoteerd (Figuur 2.3A). Op het formulier moet duidelijk worden aangegeven wat de waypoints van de start en het einde van de totale raai zijn. Waypoints voor opmerkingen (oesters, etc.) moeten apart gemaakt worden en duidelijk aangegeven worden in het formulier zijnde niet behorend tot de (sub)raaien.

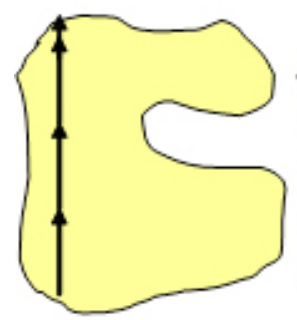

A. einde rasi

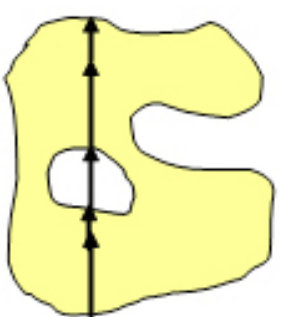

B. gat in moss el bank $>50$ stappen

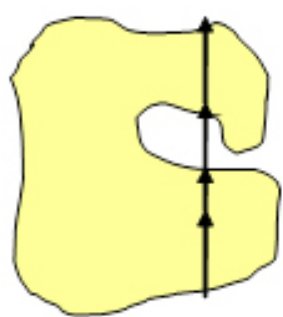

C. inham behorend tot Mosselb ank opening $<25 \mathrm{~m}$.

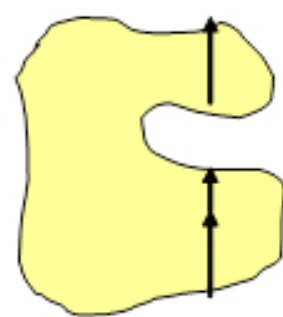

D. inham

(ing ang $>25 \mathrm{~m}$ )

Figuur 2.3 Protocol voor het lopen en markeren van raaien en subraaien. Met de pijltjes worden waypoints (locatiemarkering in de GPS) weergegeven, na 50 stappen of aan einde bank, begin of einde gat dan wel inham. Figuur $A$ geeft de situatie weer voor een raai zonder inham of gat, Figuur $B$ geeft de situatie weer voor een gat >50 stappen, Figuur $C$ een raai met een inham die bij de bank hoort (<25), en Figuur D een inham die niet bij de bank hoort $>25 \mathrm{~m}$. 
Wanneer zich een groot open stuk (gat groter dan 50 stappen) in de mosselbank bevindt waar de raai doorheen loopt dan dient de subraai te stoppen op de rand van het gat. Hier wordt weer een waypoint gemaakt. In het gat wordt een nieuwe subraai gestart. Deze subraai loopt helemaal door tot het eind van het gat (ook wanneer dit meer is dan 50 stappen), waarna weer een waypoint wordt gemaakt. Op het formulier wordt duidelijk aangegeven dat het hier om een gat in de mosselbank gaat. Na het gat wordt weer verder gelopen met subraaien totdat de raai is voltooid (Figuur 2.3B). Wanneer het gat kleiner is dan 50 stappen worden er waypoints gemaakt om de randen van het gat aan te geven en een aantekening gemaakt op het formulier betreffende dit gat. Er hoeft geen nieuwe subraai gestart te worden. Inhammen die volgens het TMAP-protocol onderdeel uitmaken van de bank (dus afstand kleiner dan $25 \mathrm{~m}$ ) worden net zo behandeld als een gat (Figuur 2.3C). Wanneer de inham niet binnen de definitie van een mosselbank valt (ingang $>25 \mathrm{~m}$ ) dient de raai afgesloten te worden bij de rand van de inham. Er wordt in dezelfde lijn als de raai door de inham gelopen totdat de mosselbank weer begint (Figuur 2.3D).

\subsubsection{Verdeling van de raaien}

De raaien worden zigzag, zoveel mogelijk in een hoofdrichting, over de mosselbank gelopen zodat de gehele mosselbank zoveel mogelijk gedekt wordt (Figuur 2.4). De hoeveelheid beschikbare tijd bepaalt de schaal van deze dekking, wanneer er veel tijd is, liggen de raaien dicht bij elkaar (Figuur 2.4A), wanneer er weinig tijd beschikbaar is liggen de raaien ruimer verdeeld (Figuur 2.4B).
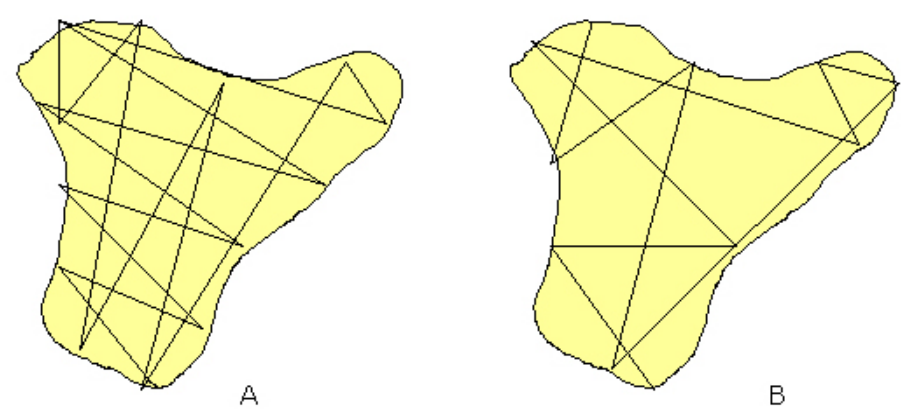

Figuur 2.4 Verdeling raaien over mosselbank. In Figuur A worden de raaien schematisch weergegeven in een situatie waarbij veel tijd is en de verschillende raaien dicht op elkaar liggen. In Figuur B wordt de ligging van de raaien schematisch weergegeven in een situatie met weinig tijd. In dat geval liggen de raaien wat verder uit elkaar maar wordt alsnog de gehele bank bestreken.

\subsubsection{Score van de mosselbedekking langs de raaien}

Per subraai wordt op het formulier aangegeven hoeveel keer er, van de 50 subraaistappen, op mosselen gestapt wordt. Dit wordt bijgehouden met een handteller. Voor alle stappen geldt dat als de voet op een mossel komt, deze stap als mosselstap telt (ongeacht of dit 1 mossel is of 10 mosselen zijn). Het bedekkingspercentage wordt vervolgens berekend uit het aantal mosselstappen ten opzichte van het totaal aan stappen.

Op de raaien wordt de aanwezigheid van oesters geschat door de oester- en mosselbedekking visueel in te schatten. Hierbij worden vijf categorieën onderscheiden (Tabel 2.1). Aan het eind van elke raai wordt een beschrijving gegeven (o.a. flora en fauna (zoals zeesla of kokkels) van de gelopen raai.

Tabel 2.1 Beschrijving schatting oesterbedekking op mosselbanken.

\begin{tabular}{llll} 
Score & Omschrijing & Oester & Mossel \\
\hline 0 & Geen & $0 \%$ & $100 \%$ \\
\hline 1 & Weinig & $0-20 \%$ & $80-100 \%$ \\
\hline 2 & Matig & $20-50 \%$ & $50-80 \%$ \\
\hline 4 & Veel & $50-80 \%$ & $20-50 \%$ \\
\hline
\end{tabular}




\subsection{Lengte-frequentieverdeling en samenstelling}

Op elke mosselbank worden 2 tot 6 'vierkantmonsters' (monsters genomen met een kwadrant, zie Tabel 2.2 voor aantal monsters per bank per jaar en Bijlage 1 voor locaties monsterpunten) genomen om informatie te verkrijgen over de lengtefrequentieverdeling van de levende mosselen en lege mosselschelpen en over de aanwezigheid van andere schelpdieren en algen.

Tabel 2.2 Aantal vierkantmonsters per mosselbank per jaar.

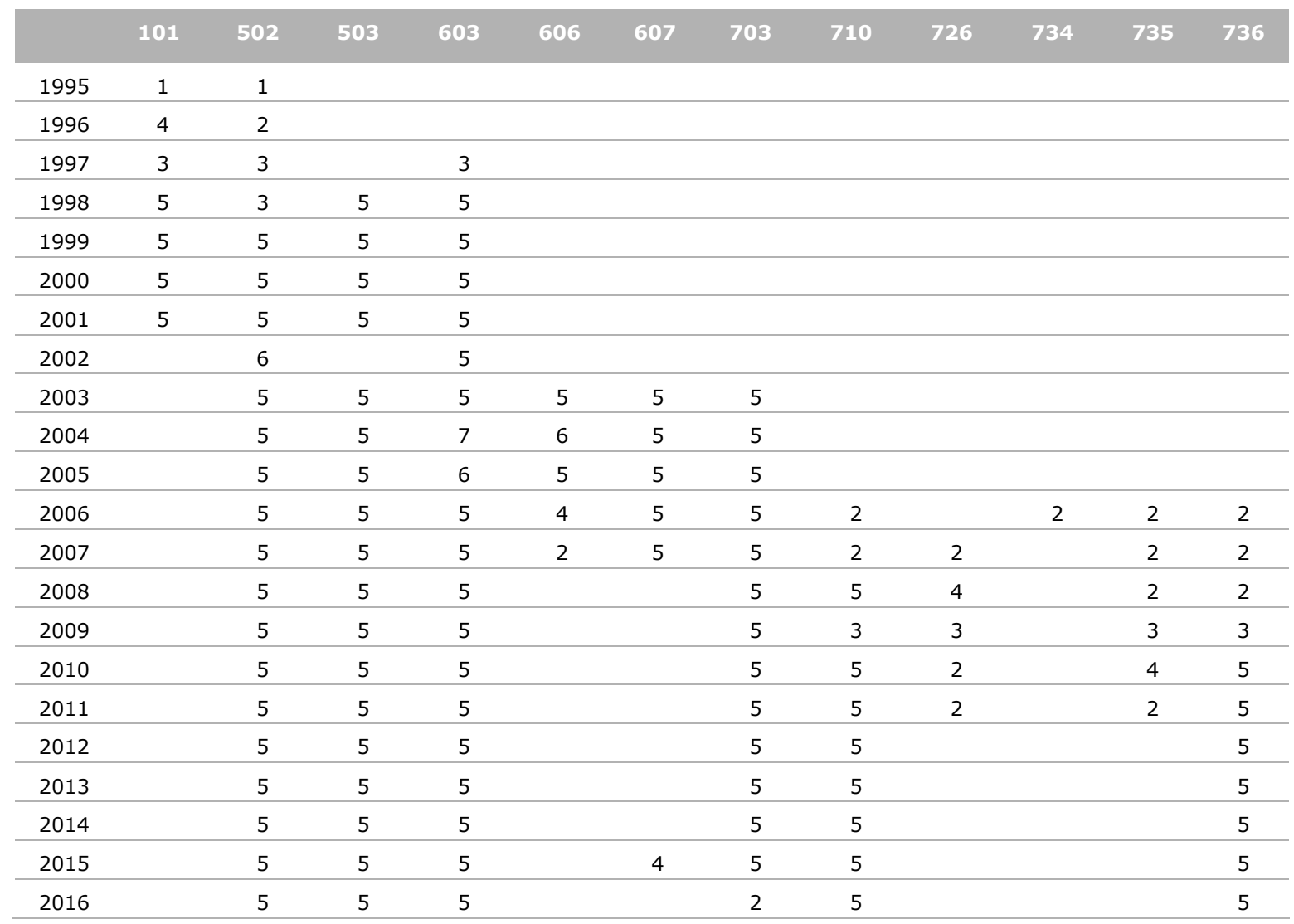

De vierkantmonsters worden jaarlijks op nagenoeg dezelfde locatie genomen, dat wil zeggen zo mogelijk binnen dezelfde mosselpatch. Op de locatie wordt een representatief deel van de mosselbank uitgekozen waar het vierkantmonster wordt genomen. Het vierkant $\left(16 \times 32 \mathrm{~cm}\left(1 / 20 \mathrm{~m}^{2}\right)\right)$ wordt in de mosselbank gedrukt totdat de bovenkant gelijk ligt met het mosseloppervlak. De toplaag van 10 $\mathrm{cm}$ wordt uit het vierkant geschraapt en in de zeef $(1 \mathrm{~mm})$ voorzichtig uitgespoeld. De exacte monsterlocatie wordt gemarkeerd met een waypoint.

In het lab worden de monsters nogmaals goed gespoeld en gezeefd (over $5 \mathrm{~mm}$ en $1 \mathrm{~mm}$ ). Het monster wordt hierdoor onderverdeeld in twee delen: grof en fijn gruis. Beide delen worden gewogen (alle gewichten in hele grammen). Hierna worden uit beide deelmonsters alle levende schelpdieren (incl. alikruiken), levende algen en lege hele mosselschelpen (doubletten en enkele) gehaald. Hierna wordt het restant grof en fijn gruis nogmaals gewogen. De pokken worden van de levende mosselen gescheiden en apart gewogen. De levende mosselen, de andere levende schelpdieren (incl. oesters), de levende algen en de lege dubbele en enkele mosselschelpen worden afzonderlijk gewogen. De aantallen per soort van de andere levende schelpdieren worden ook op het formulier vermeld.

Hierna wordt de lengte (in $\mathrm{mm}$ ) gemeten van alle levende mosselen, de andere levende schelpdieren (excl. de alikruiken) en van de enkele en dubbele lege mosselschelpen. 


\section{Resultaten}

\subsection{Ontwikkeling contouren en oppervlakte}

Elk jaar zijn de contouren van de individuele mosselbanken nauwkeurig ingemeten. Van elke contour is vervolgens het oppervlak dat bedekt was met mosselen berekend. Om het vergelijken van de contouren tussen de verschillende jaren te vergemakkelijken, zijn er kaarten gemaakt waarbij het oppervlak van het laatste jaar volledig is ingekleurd. De contouren van enkele daaraan voorafgaande jaren worden met gekleurde lijnen weergegeven (Figuur 3.1 - 3.7).

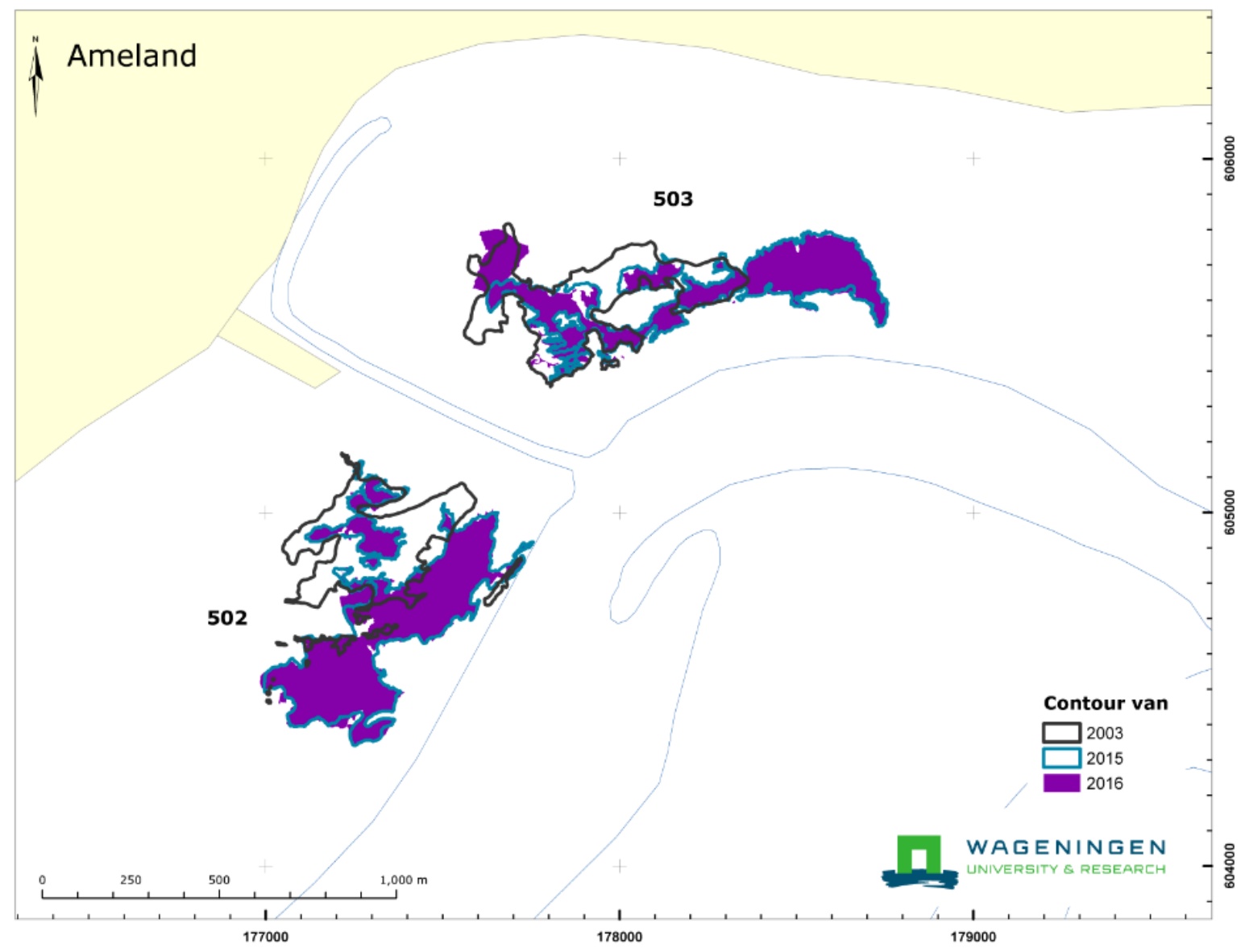

Figuur 3.1 Contouren van mosselbanken 502 en 503 (Ameland) voor de jaren 2003, 2015 \& 2016. 


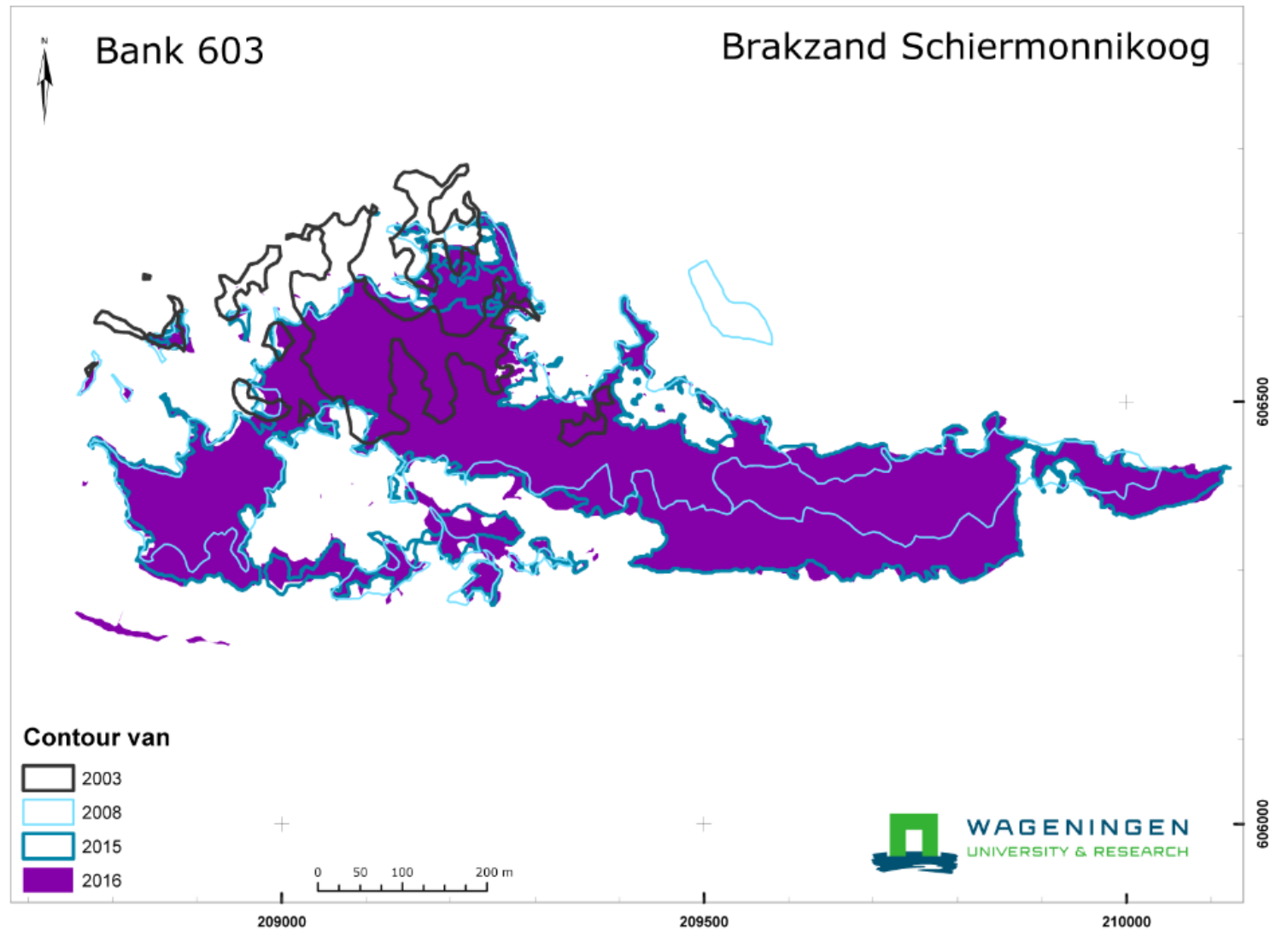

Figuur 3.2 Contouren van mosselbank 603 (Brakzand, Schiermonnikoog) voor de jaren 2003, 2008, 2015 \& 2016.

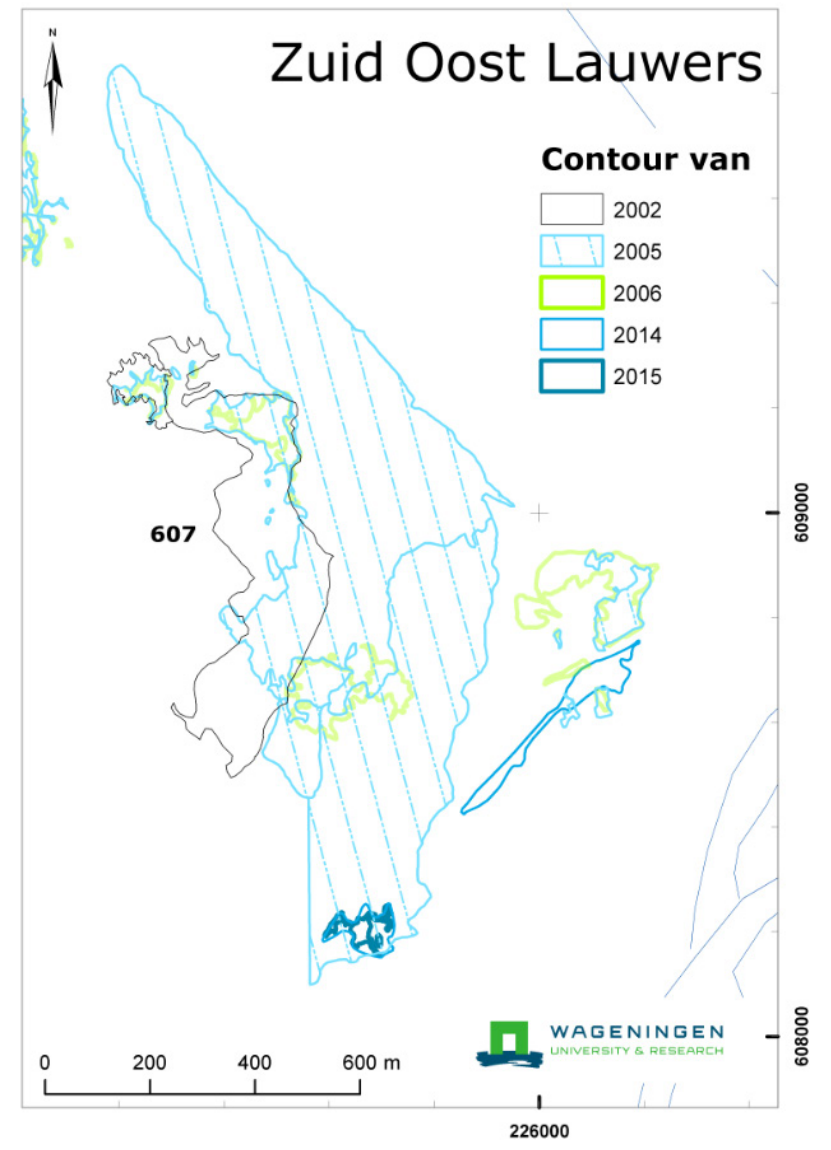

Figuur 3.3 Contouren van mosselbank 607 (Zuid Oost Lauwers Zuid) voor de jaren 2002, 2005, 2006, 2014 \& 2015. In 2016 werd deze bank niet bezocht. 


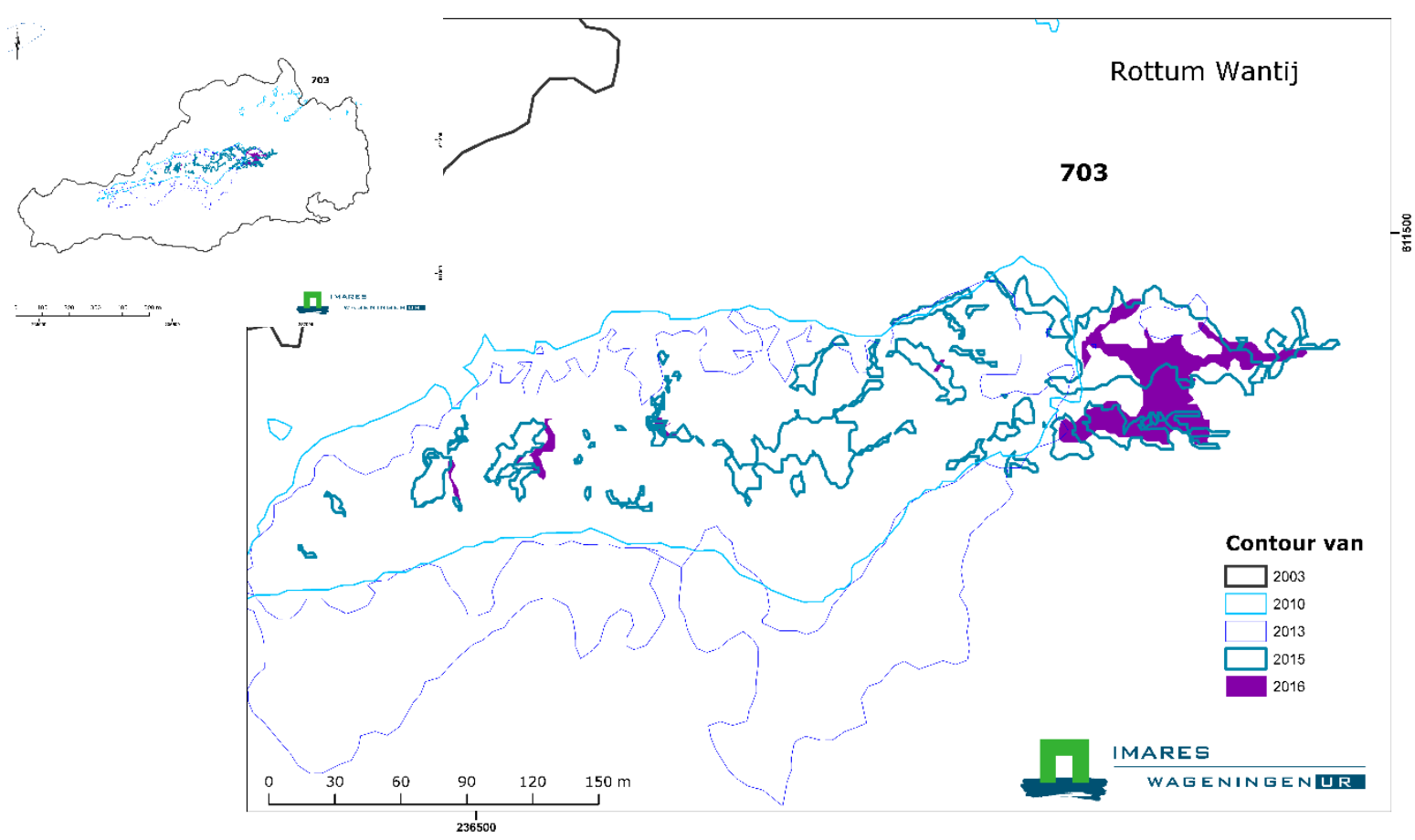

Figuur 3.4 Contouren van mosselbank 703 (Rottum Wantij) voor de jaren 2003, 2010, 2013, 2015 \& 2016.
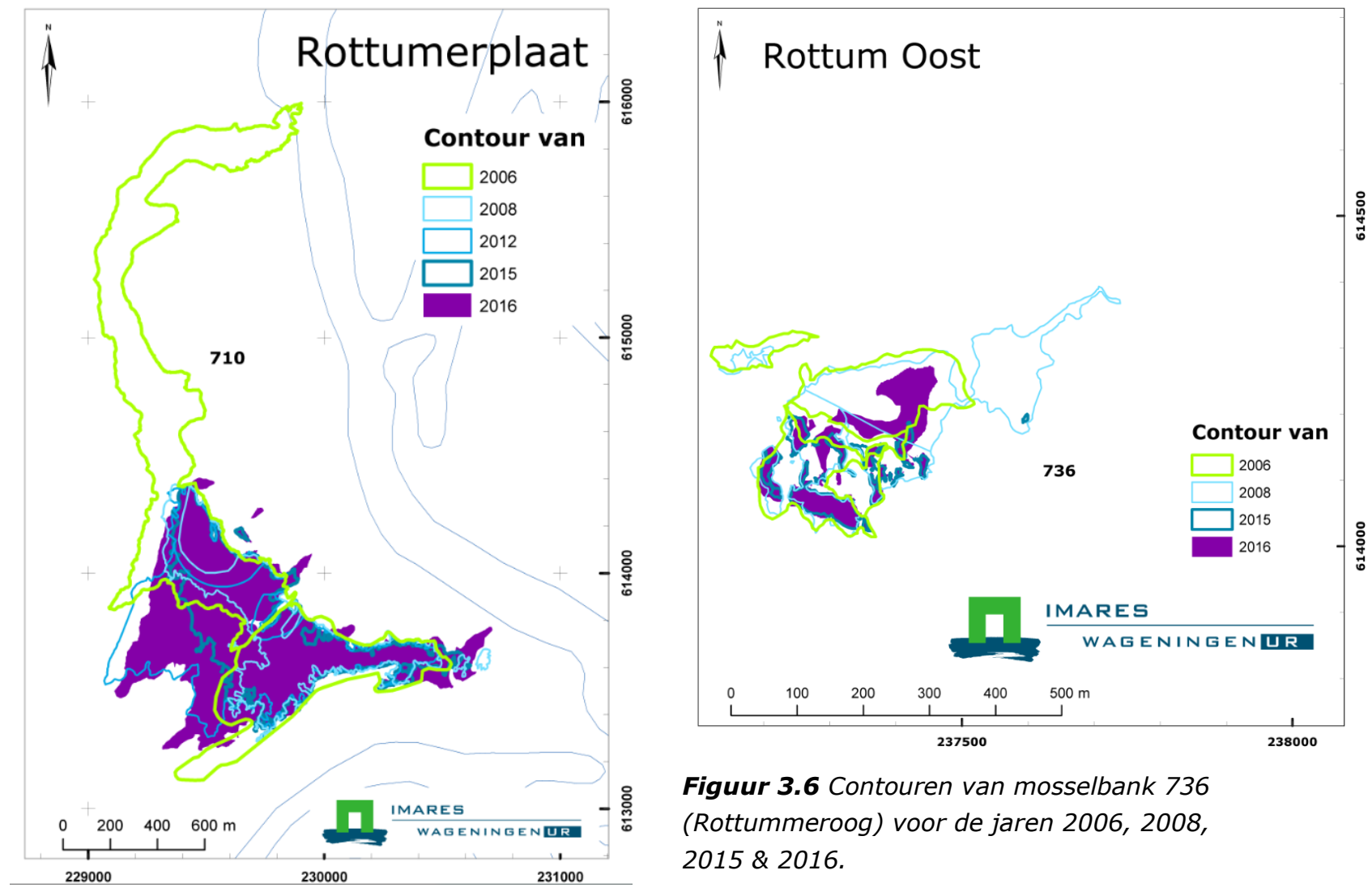

Figuur 3.6 Contouren van mosselbank 736 (Rottummeroog) voor de jaren 2006, 2008, $2015 \& 2016$.

Figuur 3.5 Contouren van mosselbank 710 (Rottumerplaat) voor de jaren 2006, 2015 \& 2016. 


\section{Ontwikkeling areaal mosselbanken}
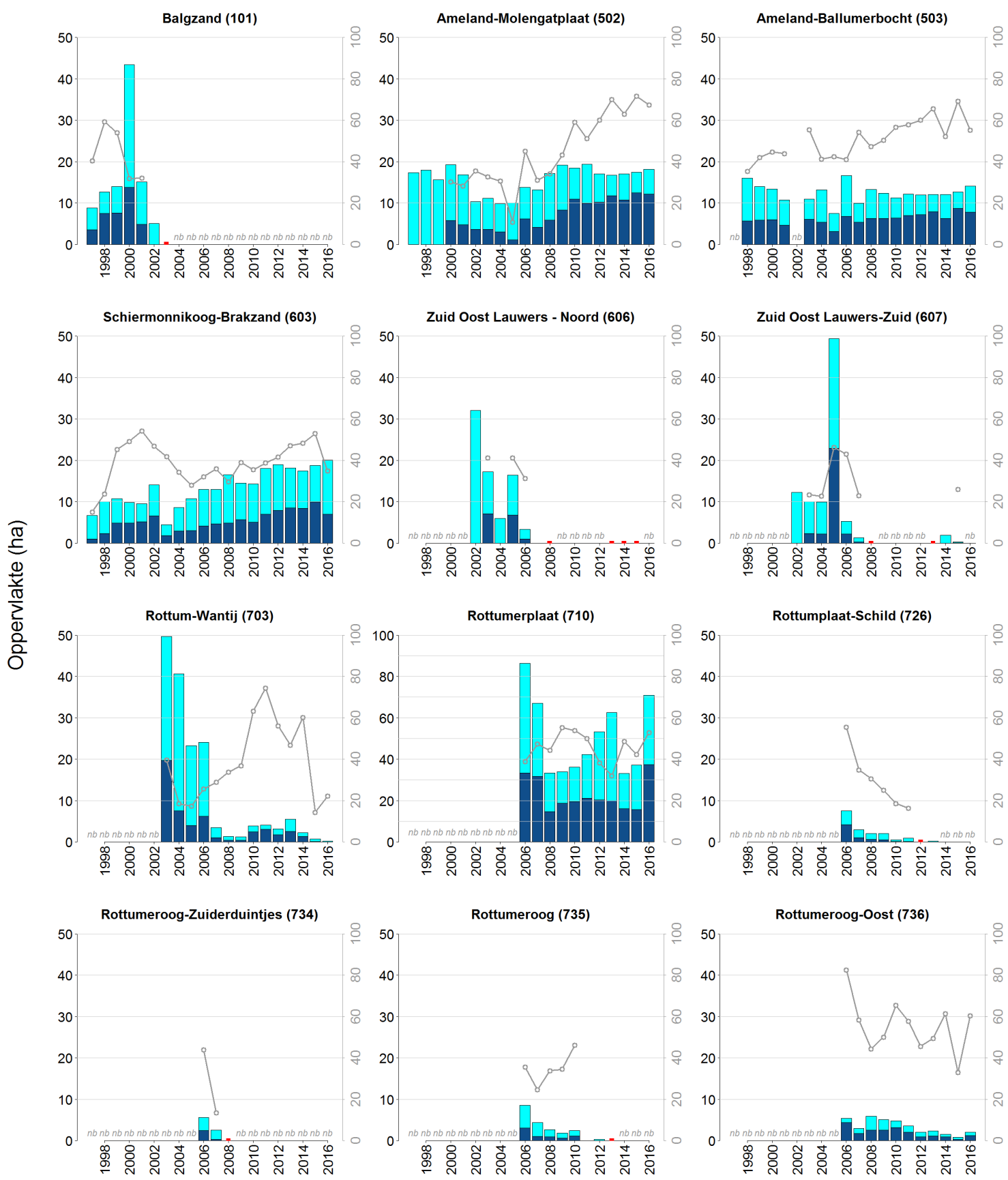

met mosselen bedekt $\square$ open plekken

Figuur 3.7 Ontwikkeling van de bankoppervlakte (in hectaren en weergegeven met balken uitgezet op de linker $y$-as) en de gemiddelde mosselbedekking (in procenten en weergegeven met een grijze gekleurde lijn uitgezet op rechter $y$-as) voor de banken 101, 502, 503, 603, 606, 607, 703, 7101, 726, 734, 735 en 736 in de periode 1997 t/m 2016 (of tot wanneer ze bezocht zijn/aanwezig waren). De hoogte van de balk (licht + donkerblauwe deel) geeft het totale bankoppervlakte weer, het donkerblauwe deel de met mosselen bedekte oppervlak en het lichtblauwe deel het areaal open plekken. Wanneer een bank wel bezocht werd maar deze niet aanwezig was is dit met een rode stip aangegeven, wanneer een bank niet bezocht is wordt dit met ' $n b^{\prime}$ ' aangegeven.

In 2014 is ervoor gekozen het noordelijke deel van bank 710 bij de bank te rekenen ondanks dat deze $>25 \mathrm{~m}$ verwijderd is. Hiervoor zijn contouren gebruikt uit Van den Ende (2015). In andere jaren is dat deel niet bij de bank gerekend en daarom is in dit rapport het areaal van het noordelijke deel van bank 710 in 2014 niet meegeteld. Wel is in andere jaren geconstateerd dat er mosselen aanwezig waren in het noordelijke deel. 
Mosselbank 503 is in 2016 aan de noordelijke zijde gegroeid. Noordelijk van deze bank werd in 2016 ook een nieuwe mosselzaadbank gekarteerd (Van den Ende et al., 2016) maar, omdat deze >25 m van de bank verwijderd is wordt deze niet bij bank 503 gerekend. Terwijl het areaal en het bedekkingspercentage in de periode 2005 - 2012 toegenomen is voor deze banken, lijkt dit de laatste jaren gestabiliseerd te zijn. Toename van de (mossel)bedekking valt samen met de introductie en verdere ontwikkeling van oesters op deze banken. In bank 502 werden voor het eerst in 2001 oesters aangetroffen in de vierkantmonsters en in bank 503 voor het eerst in 2004. Door groei is de oesterbiomassa sterk toegenomen. Ook nam de verspreiding van oesters toe en in 2008 werden, op beide banken, oesters over de gehele bank aangetroffen, zie ook par. 3.3 en Fey et al. (2014).

De mosselbanken 606 (Zuid Oost Lauwers - Noord) en 607 (Zuid Oost Lauwers - Zuid) waren grotendeels verdwenen in 2008. In 2013 werd wel enige mosselbroedval geconstateerd maar dit bleek onvoldoende voor langjarige overleving. De meeste mosselen verdwenen in de opvolgende winter en in 2015 werd alleen op 607 nog enige mosselbulten gevonden. De mosselbedekking was echter laag in 2015 (26\%) en de bank bleek in 2016 geheel verdwenen te zijn. De mosselbedekking is op deze banken nooit hogere geweest dan $50 \%$.

Sinds het jaar 2013 neemt het areaal van mosselbank 703 (Rottum Wantij) gestaag af van 5,5 ha in 2013 naar 0,25 ha in 2016. Het grootste deel van de bank verdween in 2014 toen aan de zuidelijke zijde 3.3 ha was verdwenen. In de opvolgende jaren verdween steeds ongeveer $30 \%$ van de bank waarbij ook dik bedekte delen van de bank verdwenen. In 2016 kon alleen de noordoostelijke gelegen deel van de bank nog terug gevonden werden. Gezien het kleine areaal (0,25 ha) en lage bedekking $(22 \%)$ in 2016 is het de verwachting dat zonder nieuwe broedval deze bank niet zal overleven.

De contour van bank 710 (Rottumerplaat) is erg stabiel aan de noordelijke- en oostelijke zijde en kent daar ook een hoog bedekkingspercentage tot $>80 \%$, zie de Figuren 3.5 en 3.7 en Bijlage 2. Aan de zuidwestelijke zijde bevindt zich een minder stabiel gebied welke uit meer losse mosselbulten bestaat en een lagere bedekking kent. Dit deel van de bank werd in 2014 als strooimosselen geclassificeerd ( $<5 \%$ bedekking) en niet ingetekend. In 2015 bleek de bank aan de zuidwestelijke kant iets gegroeid te zijn (bedekking >5\%). In 2016 nam de bank in dit deel nog flink verder toe, waarschijnlijk als gevolg van zaadval, waardoor ook het totale bankoppervlak flink toenam. De mosselbedekking op dit nieuwe bankdeel was echter relatief laag, namelijk tussen de $20-60 \%$ in 2016 , zie Bijlage 2 . Noordelijk van de bank werden losse bulten met jongen mosselen aangetroffen, maar omdat deze zich meer dan 25 meter van de hoofdbank bevonden en er zich bovendien een geul bevindt tussen beide bankdelen, wordt dit deel niet bij de bank gerekend.

De oppervlaktes van de mosselbanken 726 (Rottumerplaat - Schild), 734 (Rottumeroog Zuiderduintjes) en 735 (Rottumeroog) zijn over de jaren dusdanig afgenomen dat niet langer van mosselbanken gesproken kan worden.

Ook bank 736 (Rottum Oost) kent zowel een stabiel deel, gelegen aan de zuidelijke kant van de bank, en een meer instabiel deel gelegen aan de noordelijke kant van de bank. In het stabiele deel verschuiven de randen van de bank weinig en is de bedekking met mosselen hoog (tot $>80 \%$ in 2016). In het minder stabiele deel treden grote verschuivingen op in de contouren van de bank en is de mosselbedekking bovendien laag, tussen de 20 en $40 \%$ in 2016 . In 2015 is er in dit deel een groot gebied uiteengevallen waardoor het areaal met 43\% afnam. In 2016 kon het noordelijke deel wel weer bij de bank gerekend worden. De dimensies van de bank zijn daarmee in 2016 weer vergelijkbaar met de situatie zoals in 2013. Hoewel de gemiddelde mosselbedekking in 2016 vergelijkbaar was met de bedekking op de banken 502 en 503 bij Ameland, ongeveer 60\%, is de variatie over de jaren in mosselbedekking voor deze bank groter. 


\subsection{Ontwikkeling mosselabundantie}

De daling in mosselbiomassa vanaf ongeveer het jaar 2000 op de banken 502 (AmelandMolengatplaat) en 503 (Ameland - Ballumerbocht) lijkt gestopt te zijn en zich de laatste jaren te stabiliseren tot ongeveer $5 \mathrm{~kg} / \mathrm{m}^{2}$ (versgewicht). Ook de mosselpopulatie op de banken 710 (Rottumerplaat) en 736 (Rottumeroog-Oost) lijkt zich de laatste jaren te stabiliseren tot een vergelijkbare biomassa (zie ook Figuur 3.8)

\section{Ontwikkeling van de mosselpopulatie}
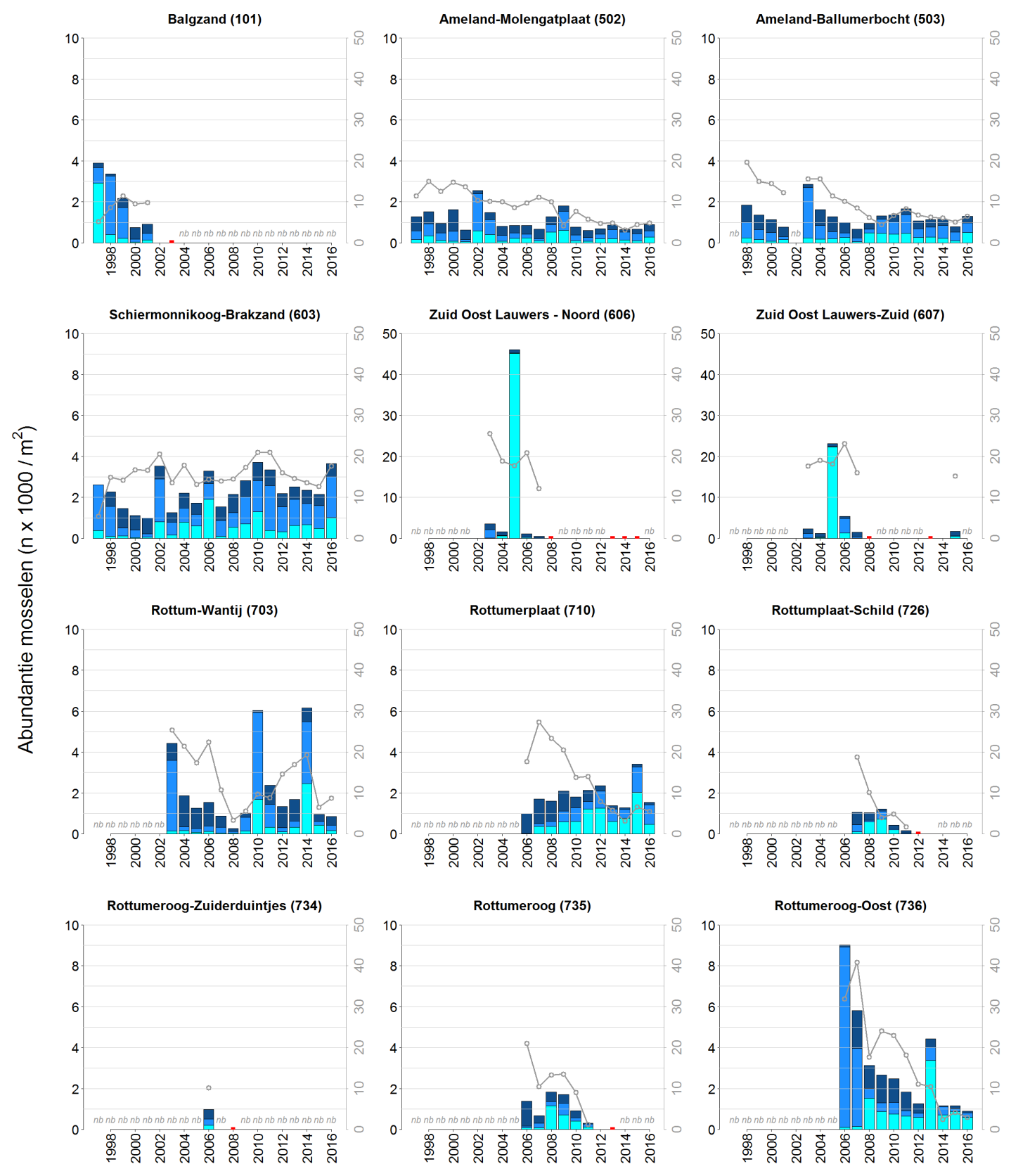

$\square 0-2 \mathrm{~mm} \square 2-4 \mathrm{~mm} \quad \square>4 \mathrm{~mm}$

Figuur 3.8 Ontwikkeling van de jaargemiddelde abundantie $\left(n \times 1000 / \mathrm{m}^{2}\right)$ en biomassa $(\mathrm{kg}$ natgewicht $/ \mathrm{m}^{2}$ ) van mosselen zoals aangetroffen in de vierkantmonsters $\left(1 / 20 \mathrm{~m}^{2}\right)$ voor de banken 101, 502, 503, 603, 606, 607, 703, 710, 726, 734, 735 en 736 in de periode 1997 t/m 2016 (of tot wanneer ze bezocht zijn/aanwezig waren). Wanneer een bank wel bezocht werd maar deze niet aanwezig was is dit met een rode stip aangegeven, wanneer een bank niet bezocht is wordt dit met ' $n b^{\prime}$ 'aangegeven. 
In de laatstgenoemde banken is het aandeel kleinere mosselen met een lengte van 0-2 cm (rond de 50-60\% van de individuen) groter dan op de banken bij Ameland (502 \& 503) en Schiermonnikoog (603) waar het aandeel kleine mosselen beduidend minder groot is, rond de $20-30 \%$. Het

bemonsteringsmoment kan dit verschil verklaren. De banken bij Ameland (502 en 503) en de bank bij Schiermonnikoog (603) worden rond mei bemonsterd terwijl de banken bij Rottum (710 en 734) rond september bemonsterd worden. In mei zijn de nieuwe mosselen net neergedaald en ongeveer $0.3 \mathrm{~mm}$ groot en gemakkelijk te missen terwijl in september dezelfde mosselen gegroeid zijn tot 5-10 mm en beter bemonsterd kunnen worden. Opvallend is de afname van het aandeel grotere mosselen op met name de banken bij Rottum (710 en 736), zie ook hierna.

\section{Lengte frequentieverdeling mosselpopulatie}
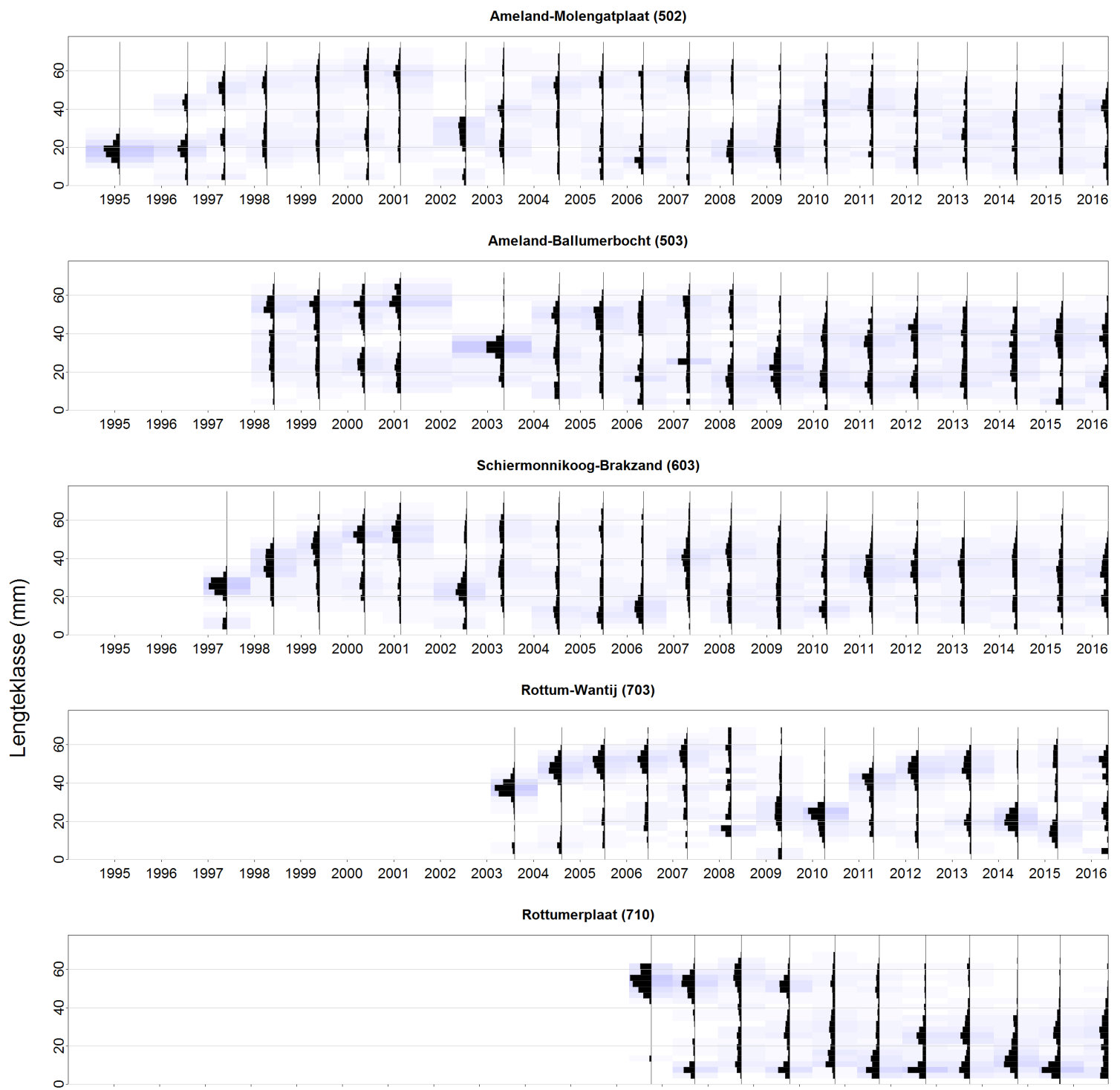

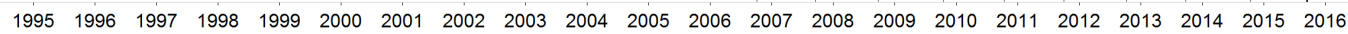

Rottumeroog-Oost (736)

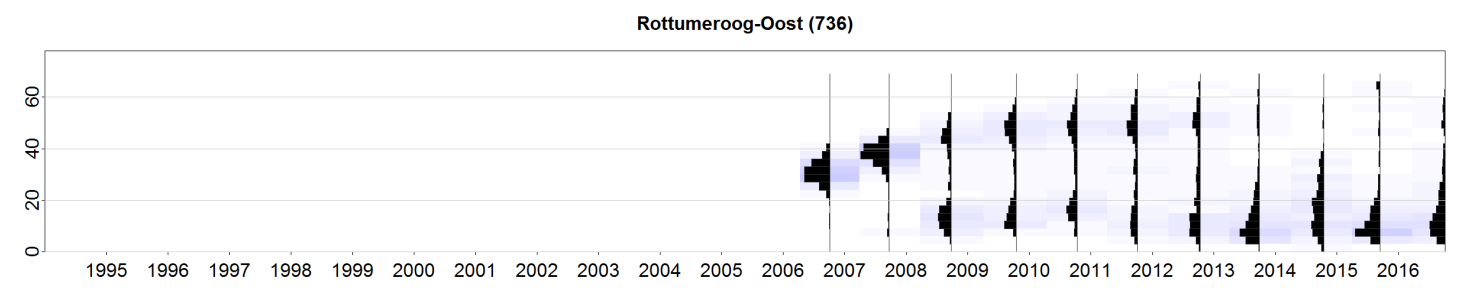

Figuur 3.9 Ontwikkeling van de lengtefrequentie (aantallen gestandaardiseerd naar 1000 mosselen en stapgrootte van $3 \mathrm{~mm}$ ) van de mosselpopulatie op de mosselbanken 502, 503, 603, 703, 710 en 736 vanaf $1995 \mathrm{t} / \mathrm{m} 2016$. 
Terwijl voor de banken bij Ameland (502 en 503) de mosselbiomassa sterk afnam na introductie van de Japanse oesters blijft de mosselbiomassa op bank 603 (Schiermonnikoog - Brakzand) blijft, stabiel rond de $15 \mathrm{~kg} / \mathrm{m}^{2}$. Hiermee kent deze bank momenteel de hoogste mosselbiomassa per vierkante meter van de banken opgenomen in dit programma.

In Figuur 3.9 is goed te zien hoe de jaarklassen van de eerste metingen op de banken 502, 603 en de banken bij Rottum (703, 710 en 736) zich over het verloop van de jaren verder ontwikkelen (groeien). $\mathrm{Na}$ ongeveer 6 jaar lijkt het eerste cohort uitgegroeid te zijn waarbij een lengte van ongeveer $60 \mathrm{~mm}$ bereikt is. Ook is goed te zien dat de banken bij Rottum ontstaan zijn enkele jaren voordat de eerste metingen uitgevoerd werden. Het prille begin van deze banken is niet gevolgd binnen dit programma; de eerste histogrammen voor deze banken pieken bij een lengteklasse van $>20 \mathrm{~mm}$ voor de eerste jaren.

Over het algemeen lijkt er op alle banken jaarlijks wel enige mosselbroed te vallen waardoor al na enkele jaren na het ontstaan van de bank meerdere jaarklassen onderscheiden kunnen worden. In de loop van de jaren zijn meestal twee, drie en soms vierjaarklassen te onderscheiden in de lengte frequentiegrafieken. In sommige jaren zijn de individuele jaarklassen in elkaar vergroeid en zijn ze niet meer goed te onderscheiden.

Er blijkt jaarlijks sprake te zijn van broedval op bank 710 en 736. Op de mosselbanken 502, 503 en 603 lijkt ook sprake te zijn van enige en jaarlijkse terugkerende broedval maar dit is, als gevolg van het bemonsteringsmoment in mei, pas zichtbaar in het jaar erop. Hierdoor zijn deze mosselen al wat groter en kan door optreden van wintersterfte wat minder duidelijk gezien worden in de lengte frequentiegrafieken. Voor deze banken (502, 503 en 603) lijkt het mosselbroed dat gevallen is in met name 2015 goed gegroeid te zijn wat ertoe geleid heeft dat in 2016 twee duidelijk verschillende jaarklassen aanwezig waren met pieken rond de 15 en $40 \mathrm{~mm}$. Opmerkelijk is dat voor alle banken de maximale grootte van de mosselen wat af lijkt te nemen.

\subsection{Oesterontwikkeling}

De biomassa mosselen en oesters en het aandeel oesters die in de monsters werden gevonden zijn weergegeven in Figuur 3.10. De oesterbedekking op de subraaien en het gemiddelde aantal- en biomassa van oesters in de vierkantmonsters is weergegeven in Bijlage 3. Zoals ook in andere jaren werd gezien en als dusdanig in de rapportages werd beschreven vindt er inmiddels een ontwikkeling van Japanse oesters plaats op alle in het onderzoek betrokken mosselbanken. Wel zijn er grote verschillen in de dominantie van oesters te zien tussen de banken. In één mosselbank lijken de mosselen pas na het ontstaan van een oesterbank te zijn gekomen (736 Rottumeroog Oost).

Het aandeel oesters in de mossel- en oesterbiomassa in mosselbank 703 (Rottum-Wantij) is minimaal te noemen; het aandeel oesters heeft nooit meer dan $10 \%$ van de mossel-/oesterbiomassa beslaan en ligt de afgelopen jaren stabiel rond de $5 \%$. De oesters op deze bank lijken bovendien klein te blijven $(<50 \mathrm{~mm})$, zie Bijlage 3, maar ook de mosselen groeien hier niet goed, zie boven. Het aandeel oesters op de banken 502 (Ameland-Molengatplaat), 503 (Ameland-Ballumerbocht), 710 (Rottumerplaat) en 736 (Rottumeroog-Oost) is vele malen groter en bepaalt momenteel $80 \%$ van de mossel- en oesterbiomassa. De bank bij Schiermonnikoog (603) neemt een tussenpositie inneemt in oesterdominantie met momenteel een aandeel van ongeveer $45 \%$ van het mossel- en oestergewicht. Wanneer de oesters uit zaad dat gevallen is in 2014 komende jaren verder groeit dan zal dit aandeel nog stijgen.

Waar het aandeel oester op de banken bij Ameland (502 en 503) al geruime tijd redelijk stabiel rond de $80 \%$ ligt, is dit voor de banken bij Rottum (710 en 736) pas meer recent het geval. Vooral een goede oesterbroedval in deze banken in 2014 en een succesvolle oestergroei in de opvolgende jaren heeft voor deze toename gezorgd. Tot nu toe worden op alle banken nog mosselen aangetroffen en hebben de oesters de mosselen dus nog niet in zijn geheel verdreven. Wel is er nog, met uitzondering van bank 703, sprake van een positieve trend in oesterbiomassa, zie Bijlage 3. 
Ontwikkeling van de Japanse oester in de mosselbanken
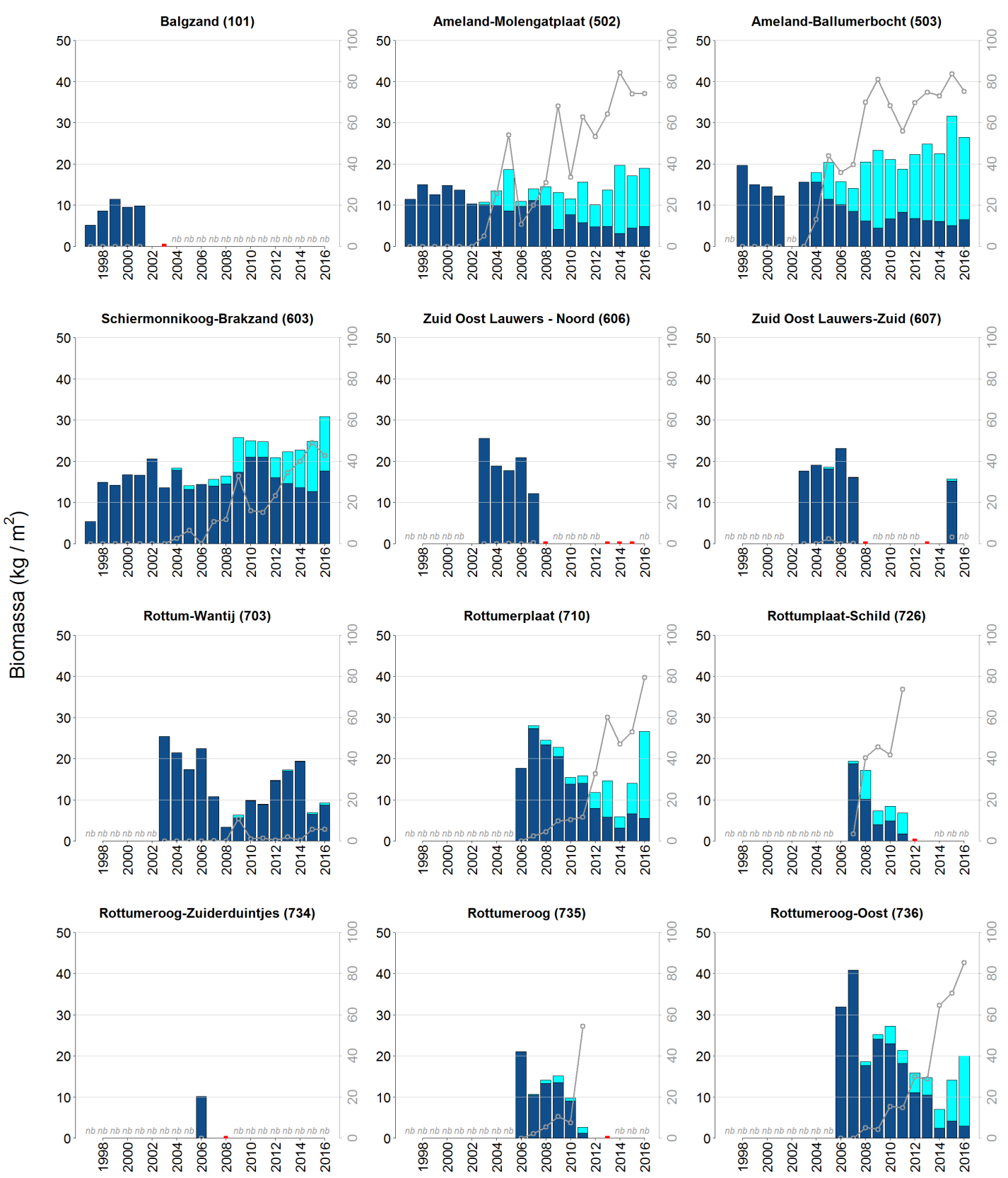

mosselen

$\square$ Japanse oesters

Figuur 3.10 Ontwikkeling van de jaargemiddelde biomassa (uitgedrukt in $\mathrm{kg}$ natgewicht $/ \mathrm{m}^{2}$ en weergegeven in balken op de linker $y$-as) mosselen en Japanse oesters en het aandeel oesters (uitgedrukt in procenten een weergegeven in grijze lijnen op de rechter $y$-as) in de mossel/oesterbiomassa zoals aangetroffen in de vierkantmonsters $\left(1 / 20 \mathrm{~m}^{2}\right)$ voor de banken 101, 502, 503, $603,606,607,703,710,726,734,735$ en 736 in de periode $1997 \mathrm{t} / \mathrm{m} 2016$ (of tot wanneer ze bezocht zijn/ aanwezig waren). Wanneer een bank wel bezocht werd maar deze niet aanwezig was is dit met een rode stip aangegeven. 


\subsection{Samenstelling leefgemeenschap op de mosselbanken}

De vierkantmonsters bestaan in het algemeen voor ongeveer 40 gewichtsprocent uit dood materiaal; voornamelijk lege mossel- en oesterschelpen. Het aandeel dood materiaal op de banken bij Rottum (710 en 736) fluctueert wat meer dan de banken bij Ameland (502 \& 503) en Schiermonnikoog (603) en piekt in sommige jaren tot rond de $80 \%$. Als gevolg van mosselsterfte neemt vooral op mosselbank 703 (Rottum-Wantij) het aandeel dood materiaal de afgelopen jaren hard toe met daarin een groot aandeel lege mosselschelpen (zie ook Figuur 3.11).
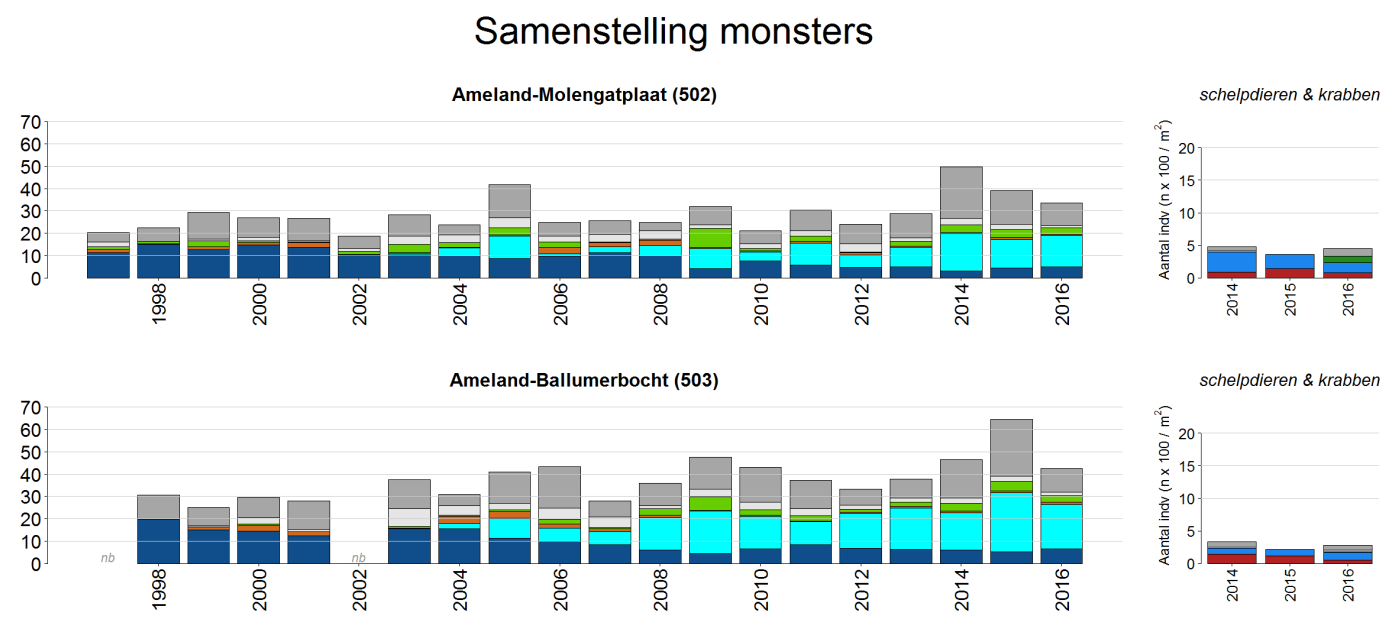

schelpdieren \& krabben
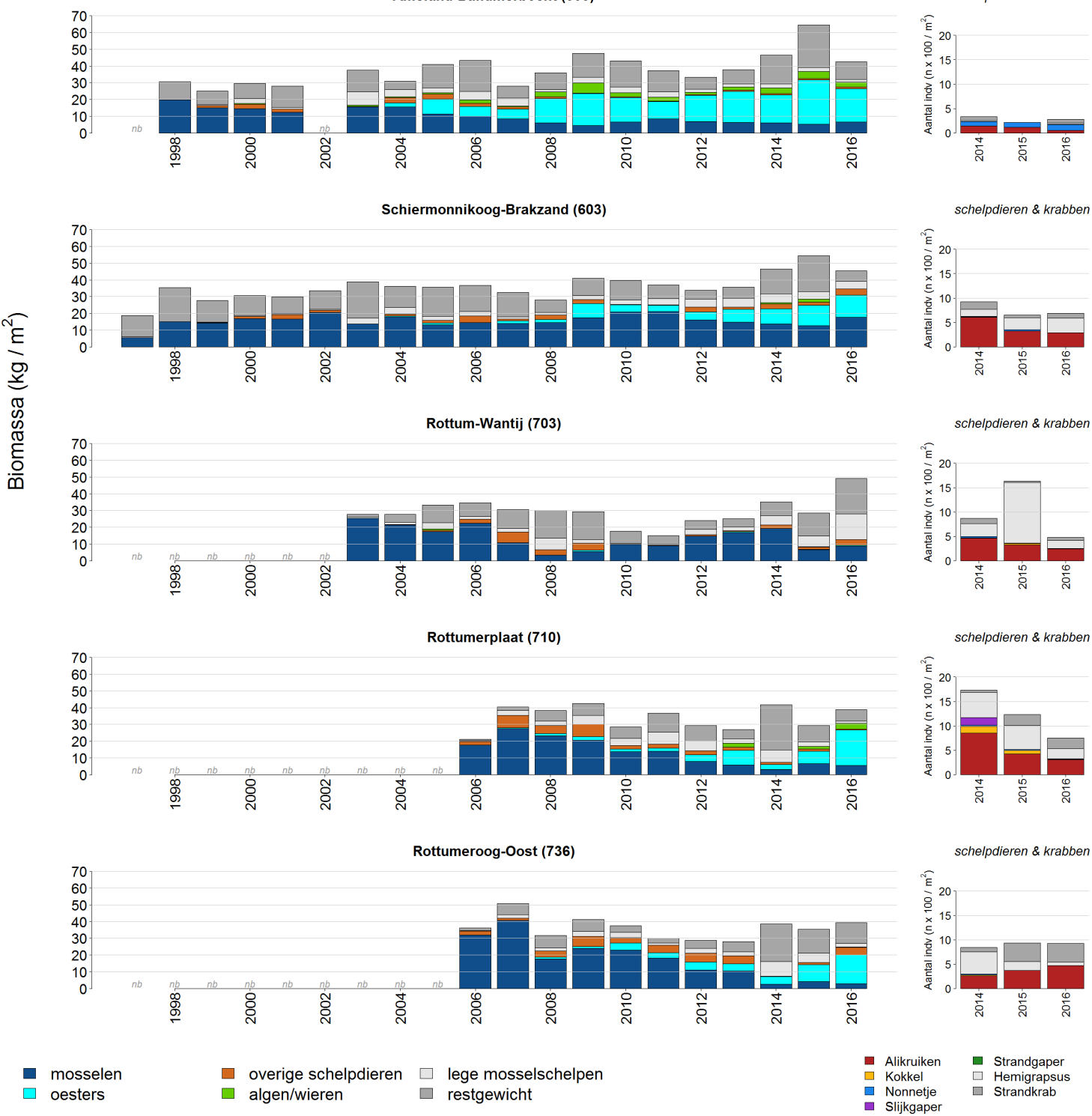

Figuur 3.11 Ontwikkeling van de gemeenschapssamenstelling zoals aangetroffen in de vierkantmonsters voor de banken 502, 503, 603, 703, 710 en 736 in de periode 1997 t/m 2016. Links gewicht mosselen, oesters, overige schelpdieren, algen/wieren, lege mosselschelpen en restgewicht, rechts dichtheid schelpdieren en krabben voor de jaren dat dit geregistreerd werd (2014 t/m 2016). 
Het aandeel mosselen is, zoals reeds eerder beschreven, gedaald als gevolg van de vestiging van oesters. Het aandeel mosselen t.o.v. het totaalgewicht is gedaald tot $10-20 \%$ bij een gelijktijdige toename in het aandeel oesters tot de $30-50 \%$.

Vooral op de banken bij Ameland (502 \& 503) worden algen en wieren aangetroffen in de vierkantmonsters. Naast mosselen en oesters komen alikruiken veelvuldig voor op alle banken evenals (kleine) krabben. Nonnetjes worden alleen op de banken bij Ameland (502 \& 503) in grote getalen aangetroffen. De krabbendichtheid is juist wat lager op de banken bij Rottum. Kokkels worden op alle banken in geringe aantallen aangetroffen maar komen vooral voor in de monsters genomen op bank 710 Rottumerplaat. Er zijn geen duidelijke trends waarneembaar in de krabbenpopulatie en de populaties van verschillende schelpdieren anders dan de reeds beschreven verschuivingen in de mossel- en oesterpopulaties.

\subsection{Ontwikkeling per individuele mosselbank}

Deze paragraaf is vergelijkbaar met Fey et al. (2015), maar wordt jaarlijks aangevuld met nieuwe informatie uit het betreffende jaar. Wanneer er in eerdere conclusies iets verandert, wordt dit specifiek aangegeven. De beschrijving van mosselbanken 101, 726, 734 en 735 verandert niet meer omdat deze banken zijn verdwenen of niet meer bezocht werden (deze teksten zijn gecursiveerd). Omdat de ontwikkeling van deze verdwenen of niet meer bezochte banken wel bijdraagt aan de onderzoeksvraag worden ze hier wel elk jaar weergegeven. De beschrijving van mosselbank 606 en 607 is wel aangepast omdat hier in 2013 nieuw broed is gevallen en deze banken in 2015 bezocht werden.

\subsubsection{Bank 101 - Balgzand}

Deze mosselbank is ontstaan met de broedval van 1992. Voor die tijd lag er een kokkelbank op die plek. De bank is voor het eerst bezocht in 1994, maar de contour is pas vanaf 1997 met gps gemeten. In 1997 is de mosselbank goed bedekt met mosselbroed en kleine mosselen uit 1996. Tot 1999 viel er regelmatig nieuw broed op de mosselbank waardoor de bedekking min of meer gelijk blijft. In 2000 is er veel broed gevallen op de mosselbank, wardoor de oppervlakte flink toenam. De jaren daarna nam de bank jaarlijks in oppervlakte en bedekking af. Vanaf 2004 is de bank niet meer bezocht in verband met een krimpend budget. Uit de jaarlijkse inventarisatie van het totale mosselareaal in de gehele Waddenzee (Van den Ende et al., 2013) blijkt dat er op die locatie nog steeds een mosselbank ligt.

\subsubsection{Bank 502 - Ameland Molengatplaat}

De mosselbank is ontstaan in 1994 en in 1995 voor het eerst bezocht. In 1999, 2001, 2005, 2007, 2011 en 2015 is er een goede mosselbroedval op de bank geweest en de bank bestaat momenteel uit twee duidelijk te onderscheiden jaarklassen.

Al 23 jaar vormt deze bank nu een stabiele structuur. De laatste jaren beslaat de oppervlakte zo'n 18 hectare. Een aantal jaren werd alleen het noordelijke deel bekeken, omdat het zuidelijke (beviste) deel enkele jaren na het ontstaan in 1994 verdween en daarna ontwikkelde als oesterbank. Omdat de gehele bank inmiddels uit oesters en mosselen bestaat, is vanaf 2009 de bedekking op de hele bank weer bepaald. De bedekking met mosselen van deze bank lijkt gestagneerd te zijn tot ongeveer $70 \%$ en is daarmee hoog in vergelijking met de andere banken opgenomen in dit programma.

In 2001 heeft er voor het eerst een oesterbroedval plaatsgevonden op de mosselbank. Vanaf 2008 werden in de gehele mosselbank oesters gevonden, maar vooral in het zuidelijke deel staan ze rechtop. Op de hele bank zijn, ook in het gedeelte met rechtopstaande oesters, nog (veel) mosselen te vinden. Om deze reden spreken we van een gemengde mosselbank. Vanaf 2012 lijkt de groei in aantal oesters op deze mosselbank enigszins te stagneren maar het gemiddeld gewicht neemt nog wel steeds iets toe. 
Het gemiddelde gewicht aan mosselen lag jaren rond de $10 \mathrm{~kg} / \mathrm{m}^{2}$. Dit is vanaf 2009 afgenomen tot minder dan $5 \mathrm{~kg}$. Dit lijkt samen te gaan met een toegenomen aandeel (in gewicht) van oesters (andere schelpdieren), lege oesterschelpen (restgewicht) en blaasjeswier (Fucus) (algen) in de mosselbank.

\subsubsection{Bank 503 - Ameland Ballumerbocht}

De mosselbank is waarschijnlijk ontstaan in 1994, maar daarna door stormen sterk achteruitgegaan. De bank vormt al minimaal 23 jaar een stabiele structuur. Door mosselbroedval uit met name 2015 is deze bank aan de noordelijke zijde wat gegroeid en is het bankoppervlak afgelopen jaren wat toegenomen tot zo'n 14 ha in 2016. Momenteel zijn duidelijk twee jaarklassen te onderscheiden. De bedekking stabiliseert de laatste jaren rond de $60 \%$. Dit wordt ook voor een deel door de oesters bepaald, vooral in het oostelijk deel. Het is bekend dat er in het oostelijk deel al vanaf 2000 veel oesters voorkwamen en dat deze zich over de zuidelijke rand van de mosselbank verder uitbreidden.

Vanaf 2004 worden oesters gevonden in de vierkantmonsters. Vanaf 2008 zijn in de gehele mosselbank oesters te vinden, maar vooral in het zuidelijke deel vormen ze rechtopstaande structuren. De oesterbedekking lijkt zich de laatste jaren enigszins te stabiliseren. Overal zijn nog (veel) mosselen te vinden. Om deze reden spreken we de laatste jaren van een gemengde mosselbank. In het noordelijke deel overheersen de mosselen en is het percentage oesters lager. Het mosselgewicht per oppervlakte-eenheid lijkt tot 2010 jaarlijks iets af te nemen, maar daarna te stabiliseren. Afgelopen periode (vanaf 2012 tot en met 2016) ligt het mosselgewicht rond de $5 \mathrm{~kg} / \mathrm{m}^{2}$.

\subsubsection{Bank 603 - Schiermonnikoog Brakzand}

De mosselbank is ontstaan in 1994 en in 1995 voor het eerst bezocht. Al meer dan 20 jaar vormt de bank een stabiele structuur. De bank bestaat uit mosselen met oesters en er zijn veel diepe, snelstromende geulen. De oppervlakte van de bank neemt over de jaren langzaam toe en beslaat nu zo'n 20 ha.

In 1997 bestond de mosselbank uit broedval van 1995 en 1996. In 2005, 2007, 2009 en in 2015 is er een behoorlijke broedval geweest op deze mosselbank de mosselen op de bank beslaan nu uit twee duidelijk te onderscheiden jaarklassen. De bedekking met mosselen schommelt al jaren stabiel rond de $40 \%$. De laatste jaren lijkt het mosselgewicht per oppervlakte-eenheid stabiel te blijven rond de 15 $\mathrm{kg} / \mathrm{m}^{2}$. Het aandeel overige levende tweekleppige schelpdieren en slakken is vanaf 2005 toegenomen.

In 2004 werden voor de eerste keer enkele (jonge) oesters aangetroffen in de vierkantmonsters. De oesters nemen jaarlijks toe en hebben zich in 2007 verder uitgebreid over het centrale deel van de mosselbank en momenteel bestaat de mossel-oesterbiomassa voor $45 \%$ uit oesters. Door vooral groei van oesters is het de verwachting dat dit aandeel nog zal toenemen. In 2009 bleek dit middelste deel voor een groot deel uit oesters te bestaan, waartussen ook nog veel mosselen zaten. Niet overal staan de oesters al rechtop.

\subsubsection{Bank 606 - Zuid Oost Lauwers Noord}

De bank is ontstaan in 2001 en voor het eerst bezocht in 2002. Over de jaren is het bankoppervlak vrij snel afgenomen, hoewel in 2005 nog een toename door nieuwe broedval te zien was. Ook de bedekking nam snel af. Deze bank is sinds 2008 geheel verdwenen. In 2011 en 2012 is de locatie niet bezocht. In het voorjaar van 2013 bleek de bank nog steeds geheel verdwenen, op sommige plekken leefden wel veel zandkokerwormen. In het najaar van 2013 bleek er nieuw broed te zijn gevallen. Dit was echter in de daaropvolgende winter geheel verdwenen.

\subsubsection{Bank 607 - Zuid Oost Lauwers Zuid}

De kern van deze bank is ontstaan in 2000 en in 2002, na de zaadval van 2001, voor het eerst goed ingemeten. In 2005 viel veel nieuw mosselbroed op deze locatie, waardoor de oppervlakte en de bedekking toenam. Het nieuwe mosselbroed was in 2006 al weer grotendeels verdwenen, waardoor de oppervlakte van de bank weer terugviel tot die van 2004. Daarna ging de bank jaarlijks in oppervlakte 
en bedekking achteruit, tot deze in 2008 geheel was verdwenen. In 2011 en 2012 is de locatie niet bezocht. In het voorjaar van 2013 leek de bank nog steeds geheel verdwenen, op sommige plekken leefden nu veel zandkokerwormen. In het najaar van 2013 bleek er nieuw broed te zijn gevallen. Dit was echter in de daaropvolgende winter grotendeels verdwenen. In 2015 werden nog enige mosselbulten gevonden, de bank was toen 0,3 ha groot en kende een lage mosselbedekking van $26 \%$. De bank leek in 2016 geheel verdwenen te zijn.

\subsubsection{Bank 703 - Rottum Wantij}

Deze mosselbank is ontstaan in 2001 en in 2003 voor het eerst bezocht. De oppervlakte van deze bank nam de daaropvolgende jaren snel af.

De mosselbank bestond in 2009 alleen nog maar uit enkele (weliswaar grote) bulten die nog waren overgebleven van de oorspronkelijke mosselbank. Tussen deze bulten lag een groot slibvlak met kokkels, kokkelschelpen, mosselschelpen, pokken en strooimosselen. In de zomer van 2009 is nieuw mosselbroed gevallen op deze schelpenresten welke in de opeenvolgende jaren goed is gegroeid. De mosselbank is hierdoor weer in oppervlakte en bedekking toegenomen. In 2012 is er aan de oostkant een klein deel weggeslagen, maar in 2013 is het zuidelijke deel verder uitgebreid door wederom een mosselbroedval. Overleving was echter slecht en in 2014 is de oppervlakte weer afgenomen met name doordat het zuidelijke deel is verdwenen (zo'n 3,3 ha). In de volgende jaren verdween steeds ongeveer $30 \%$ van het bankoppervlak waarbij ook dik bedekte delen verdwenen. Het gewichtsaandeel dood (schelpen)materiaal nam de afgelopen jaren toe tot $80 \%$. Momenteel (2016) is het bankoppervlak 0,25 ha groot en is de bedekking laag. Zonder nieuwe broedval zal deze bank niet lang overleven.

Op deze mosselbank wordt vanaf 2006 (start van het volgen van de oesterontwikkeling) af en toe een enkele oester waargenomen. In 2011 leek een kleine oesterbroedval te hebben plaatsgevonden. Ook in de opvolgende jaren worden steeds geringe aantallen oesters gevonden ( $5 \%$ van de mosseloesterbiomassa) maar de oesters lijken niet hard te groeien.

\subsubsection{Bank 710 - Rottumerplaat}

Het betreft een mosselbank die in het najaar van 2006 voor het eerst is bezocht. Waarschijnlijk is de mosselbank ontstaan uit de broedval van 2001 (Steenbergen et al., 2003). Het slikkige noordelijke deel, dat in 2006 en 2007 nog aanwezig was, is in 2008 geheel verdwenen. Hierdoor halveerde toen de mosselbankoppervlakte. Daarna nam de oppervlakte weer langzaam toe, met name omdat in 2011 in het zuidwestelijke deel nieuw mosselbroed was gevallen. Dit deel had zich goed gevestigd en breidde elk jaar iets uit. De bedekking nam wel af en in 2014 is dit deel zo weinig bedekt $(<5 \%)$ dat het als strooimosselen wordt geclassificeerd en niet meer meetelt in de oppervlakte. Door zaadval in het zuidwestelijke deel is de bank op die plek weer gegroeid in 2015 en in 2016. De bedekking in dit deel is wel relatief laag, namelijk $20-60 \%$ in vergelijking tot $>80 \%$ in het noordoostelijke deel.

Er wordt nagenoeg elk jaar een mosselbroedval geconstateerd op deze bank. De mosselen op deze bank zijn relatief klein maar bestaan wel uit meerdere jaarklassen. De mosselbank bevat op sommige plekken, net als in voorgaande jaren, ook veel oesters. De mosselbiomassa loopt sinds 2007 terug (toen er $27 \mathrm{~kg} / \mathrm{m}^{2} \mathrm{lag}$ ) en ligt de afgelopen jaren rond de $5 \mathrm{~kg} / \mathrm{m}^{2}$. De biomassa oesters is flink toegenomen, vooral door een goede oesterbroedval in 2014 die bovendien goed bleken te groeien in de jaren erna.

\subsubsection{Bank 726 - Rottumerplaat Schild}

Deze mosselbank is in het najaar van 2006 voor het eerst bezocht. Waarschijnlijk is de bank ontstaan uit de broedval van 2001 (Steenbergen et al., 2003). In 2007 is een goede broedval geweest die resulteerde in een hoog percentage kleine mosselen in 2008. De mosselbank nam jaarlijks (lineair) in oppervlakte en bedekking af, waarschijnlijk door stormen. De laatste jaren bestond de mosselbank voornamelijk uit oesters met oude mosselen ertussen. Het nieuwe zuidelijke deel (2008) bestond voornamelijk uit jonge oesters op dode schelpen van strandgaper, kokkel en mossel. In 2010 was dit deel verdwenen, waarschijnlijk als gevolg van stormschade. De delen met grote oesters leken langer 
dichter bedekt te blijven. Het overgebleven deel was in 2012 zo klein en de bedekking was toen zo laag, dat niet langer over een mosselbank gesproken kan worden. Het hele oorspronkelijke mosselbankoppervlak lag in de jaren daarna vol met dode schelpen van mossel, strandgaper, kokkel en oesters. Sindsdien is op deze bank de oppervlakte en bedekking niet meer bepaald en zijn geen monsters meer genomen.

\subsubsection{Bank 734 - Rottumeroog Zuiderduintjes}

In het najaar van 2006 werd deze plek binnen dit project voor het eerst bezocht. Waarschijnlijk is de mosselbank ontstaan uit de broedval van 2001 (Steenbergen et al., 2003). Vanaf 2006 ging de bank jaarlijks in oppervlak en bedekking achteruit tot er in 2008 niets meer van over was. In 2008 was de mosselbank geheel verdwenen en vanaf 2009 wordt de bank niet meer bezocht.

\subsubsection{Bank 735 - Rottumeroog}

Het betreft een mosselbank die in het najaar van 2006 voor het eerst is bezocht. Waarschijnlijk is de mosselbank ontstaan uit de broedval van 2001 (Steenbergen et al., 2003). De oorspronkelijke mosselbank nam sinds 2006 jaarlijks (lineair) in oppervlakte af. In 2008 en 2009 was er een goede broedval op deze bank, daarna vond geen noemenswaardige broedval meer plaats en is de bank ook in bedekking langzaam achteruitgegaan. Vanaf 2006 werd een enkele losliggende oester waargenomen, vanaf 2007 kwamen ze ook voor in de vierkantmonsters. Jaarlijks nam dit aantal toe, maar er kwamen nog steeds voornamelijk mosselen voor op de mosselbank. Een losliggend deel aan de westkant bevatte wel meer oesters. Het gewicht aan levende mosselen leekt te stabiliseren rond de $10 \mathrm{~kg} / \mathrm{m}^{2}$. In 2011 nam dit plots af tot $<2 \mathrm{~kg} / \mathrm{m}^{2}$. Het aandeel oesters en lege schelpen (anders dan mosselschelpen) leek de afgelopen jaren langzaam toe te nemen. Het lijkt of er in 2010 zand over de bank is gespoeld, er lag toen veel zand op en tussen de mosselen. In 2012 was deze mosselbank geheel verdwenen.

Vanaf die tijd zijn geen monsters meer genomen op deze mosselbank. In 2010 zijn er ten westen twee nieuwe mosselbanken ontstaan uit mosselbroed van 2008, vlak naast de oorspronkelijke mosselbank die toen nog steeds aanwezig was. Deze zijn niet meegenomen in de oppervlakteberekeningen. De nieuwe mosselbanken ten westen van de oude zijn nog steeds aanwezig en in 2013 is er weer nieuw mosselbroed gevallen op die locatie.

\subsubsection{Bank 736 - Rottumeroog Oost}

De mosselbank lijkt ontstaan uit de broedval van 2005, in 2006 is deze locatie binnen dit project voor het eerst bezocht. De mosselbank ligt in de luwte van een ouder oesterrif dat het zuidwestelijke deel beslaat. Mogelijk dat hier eerder al wel mosselen hebben gelegen (Steenbergen et al., 2003). Het oesterrif zorgde waarschijnlijk voor een sterke rand die afkalving aan de zuidzijde voorkomt. In 2007 bleek dat in een groot deel van het oesterrif zoveel mosselen waren gestroomd, of als broed gevallen, dat van een gemengd deel gesproken kon worden. De laatste jaren zijn er wel delen van dit rif verdwenen.

De vierkantmonsters zijn alleen in het mosseldeel genomen. Hierin kwamen tot 2008 nauwelijks oesters voor, in 2010 is het aantal oesters in dit middendeel flink toegenomen. In 2014 heeft er een oesterbroedval op de bank plaatsgevonden welke in de opvolgende jaren goed gegroeid bleek te zijn.

In 2014 zijn er, net als voorgaande jaren, aan de noordzijde delen verdwenen. In 2014 lag er erg veel schelpengruis op de bank, zowel van mosselen als van andere schelpdieren. Waarschijnlijk is er veel doodgegaan op deze mosselbank, mogelijk door stormschade. De resterende mosselbank heeft grote hoogteverschillen met mosselbulten van ongeveer 1 meter hoog. De oppervlakte nam vanaf 2009 steeds af en in 2015 verdween aan de noordelijke kant een groot stuk mosselbank waarna 0,8 ha overbleef. Na broedval in 2016 kon dit stuk wel weer tot de bank gerekend worden waardoor het areaal steeg naar 2 ha. Het gewicht aan levende mosselen leek te stabiliseren rond de $20 \mathrm{~kg} / \mathrm{m}^{2}, \mathrm{maar}$ nam vanaf 2012 sterk af en bedraagt momenteel ongeveer $3 \mathrm{~kg} / \mathrm{m}^{2}$. 


\section{$4 \quad$ Discussie en conclusie}

Wageningen Marine Research bestudeert in detail de ontwikkelingen op lange termijn van een zevental mosselbanken. Drie daarvan worden sinds voorjaar 1997 gevolgd, één sinds voorjaar 1998, twee mosselbanken worden sinds voorjaar 2002 gevolgd en één sinds voorjaar 2003. Naast deze mosselbanken wordt sinds najaar 2006 een vijftal mosselbanken in detail bestudeerd naar aanleiding van andere onderzoeksprojecten, deze mosselbanken worden in deze rapportage ook meegenomen (710, 726, 734, 735 en 736). In het voorjaar van 2016 werden de mosselbanken 502 (Ameland Molengatplaat), 503 (Ameland Ballumerbocht), 603 (Schiermonnikoog), 606 (Zuid Oost Lauwers Noord) en 607 Zuid Oost Lauwers Zuid) bezocht. In het najaar werden de banken 703 (Rottum Wantij), 710 (Rottumerplaat) en 736 (Rottumeroog-Oost) bezocht.

Mosselbanken 502, 503 en 603 bestaan inmiddels zeker 20 jaar op dezelfde locatie. Deze banken zijn erg stabiel in oppervlakte en bedekking en vertonen de laatste jaren over het algemeen alleen kleine veranderingen. In 2015 heeft op alle banken mosselbroedval plaatsgevonden en momenteel bestaan de banken uit mosselen van meerdere jaarklassen. Op deze drie banken leven ook oesters die met name in 502 en 503 een groot deel van de schelpdierbiomassa uitmaken. Het oestergewicht neemt toe, door groei van individuele oesters en in het geval van bank 603 daarnaast ook door oesterbroedval uit 2014.

Van de drie mosselbanken die sinds voorjaar 2002/2003 worden gevolgd (606, 607 en 703) zijn er twee in 2007 verdwenen (606 en 607). Deze banken zijn 6 tot 7 jaar aanwezig geweest. Opleving van bank 607 in 2014 na broedval leek geen stand te houden. Mosselbank 703 is inmiddels 16 jaar aanwezig. De mosselbank is de eerste jaren in het onderzoek behoorlijk in oppervlakte achteruitgegaan. In 2009 (zichtbaar in 2010) in 2013 (zichtbaar in 2014) en in 2014 (zichtbaar in 2015 ) is nieuw broed op deze bank gevallen, maar overleving was slecht en het oppervlak is sterk afgenomen. De overlevingskansen van deze bank worden als laag ingeschat. Dit is de enige mosselbank binnen dit project waar nog geen noemenswaardige oesterontwikkeling plaatsvindt.

Van de mosselbanken die sinds 2006 worden gevolgd (710, 726, 734, 735 en 736) is mosselbank 734 maar enkele jaren aanwezig geweest, mosselbanken 726 en 735 lagen er meer dan 10 jaar. Deze banken zijn inmiddels verdwenen. Mosselbank 710 bestaat waarschijnlijk 15 jaar, mosselbank 736 waarschijnlijk 11 jaar. Deze banken laten in vergelijking met banken 502, 503 en 603 grotere fluctuaties zien in oppervlakte en bedekking. Jarenlange aanwezigheid van deze banken toont echter aan dat ook banken waarvan het oppervlakte wat sterkere jaarlijkse fluctuaties laat zien een stabiele mosselbank kunnen vertegenwoordigen.

Bij de meeste mosselbanken uit dit onderzoek zijn inmiddels delen van het oppervlak bezet met oesters die bovendien in de meeste gevallen de schelpdierbiomassa domineren. Op mosselbanken 603, 710 en 736 heeft in 2014 een flinke oesterbroedval plaatsgevonden die goed lijken te groeien.

De resultaten van de jaarlijkse kartering en populatiemeting geven een beeld van de ontwikkeling van mosselbanken over een groot aantal jaren. De algemene conclusie, die ook al in voorgaande tussenrapportages wordt beschreven (o.a. Fey et al., 2014), verandert daarmee niet. De mosselbanken gaan in het algemeen na het jaar van ontstaan langzaam in oppervlakte, bedekkingspercentage en populatiedichtheid achteruit. Op de mosselbanken neemt dan het percentage lege schelpen, algen, zeepokken en restgewicht toe in verhouding tot de levende mosselen. De afname in oppervlakte en bedekking wordt af en toe teniet gedaan door een goede broedval, waarna het proces opnieuw begint. Over de jaren ontstaat dus geleidelijk een mosselbank met meerdere jaarklassen en met een gevarieerde gemeenschap. Introductie van Japanse oesters in bestaande mosselbanken blijkt een algemeen verschijnsel wat resulteert in een hoger bedekkingspercentage en afname in biomassa mosselen. Ondanks de overeenkomsten in algemene ontwikkeling, zijn er jaarlijks grote verschillen te zien in de ontwikkeling tussen individuele mosselbanken. Sommige banken nemen in oppervlakte en 
bedekking af, andere juist toe. Op sommige mosselbanken vindt een mossel- of oesterbroedval plaats, op andere niet, etc. Deze verschillen kunnen ontstaan door locatie (en dus blootstellingen aan storm of predatie) of door karakteristieken van de mosselbank (de mate waarin deze bestand is tegen stormen en predatie).

Mosselbanken op een bepaalde locatie kunnen dus een stabiel en langdurig verschijnsel zijn, al kunnen individuele mosselen en zelfs delen van de mosselbank veel korter aanwezig zijn. Belangrijke factoren in de ontwikkeling van mosselbanken zijn predatie, klimatologische parameters, fysische parameters en nieuwe broedval of instroom van volwassen mosselen en/of oesters (Dankers \& Fey, 2015).

De hier gepresenteerde meerjarige gegevens met betrekking tot de ontwikkeling van mosselbanken kunnen bijdragen aan meer kennis van de eigenschappen die al dan niet overleven van mosselbanken bepalen evenals de invloed van oesters op de mosselpopulatie 


\section{Literatuur}

Asmus R,M. en H. Asmus (1991) Mussel beds: limiting or promoting phytoplankton? Journal of Experimental Marine Biology and Ecology 148:215-32.

Brinkman AG, T Bult, N Dankers, A Meijboom, D den Os, MR van Stralen, J de Vlas (2003) Mosselbanken kenmerken, oppervlaktebepaling en beoordeling van stabiliteit. Alterra rapport 707. Alterra Wageningen UR, Wageningen.

Brinkman AG (2003) Estimation of length and weight growth parameters in populations with a discrete reproduction characteristic, 2nd edition. Alterra-DLO rapport 93/5. Alterra Wageningen UR, Wageningen.

Buschbaum, C. S. Dittmann, J-S Hong, I-S Hwang, M. Strasser, M. Thiel, N. Valdivia, S-P Yoon, K. Reise (2009) Mytilid mussels: global habitat engineers in coastal sediments. Helgoland Marine Resources 63:47-58.

Dame, R.F., N. Dankers, T. Prins, H. Jongsma \& A. Smaal (1991) The influence of mussel beds on nutrients in the western Wadden Sea and Eastern Scheldt estuaries. Estuaries 130-138-14.

Dame, R.F. (2011) Ecology of marine bivalves: an ecosystem approach, $2^{\text {nd }}$ edition. Boca Raton, FL, CRC Marine Sciences. 283 pp.

Dankers N \& K Koelemaij (1989) Variations in the mussel population of the Dutch Waddensea in relation to monitoring. Helgwiss. Meeresunters. 43: 529-535.

Dankers N; Meijboom A; Cremer JSM; Dijkman EM; Hermes Y; te Marvelde L (2003) Historische ontwikkeling van droogvallende mosselbanken in de Nederlandse Waddenzee. Alterra-rapport 876. Alterra Wageningen UR, Wageningen.

Dankers N; Meijboom A; de Jong M; Dijkman E; Cremer J; van der Sluis S (2004) Het ontstaan en verdwijnen van droogvallende mosselbanken in de Nederlandse Waddenzee. Alterra-rapport 921. Alterra Wageningen UR, Wageningen.

Dankers N; Meijboom A; de Jong M; Dijkman E; Cremer J; Fey F (2006) Ontwikkeling van mosselbanken in de Nederlandse Waddenzee: situatie 2004 en 2005. Interne rapportage Wageningen IMARES 06.009, Texel.

Dankers N, Cremer J, Dijkman E, Brasseur S, Dijkema K, Fey F, de Jong M, Smit C (2006) Ecologische Atlas Waddenzee. IMARES Wageningen UR, Texel.

Dankers, N. \& Fey-Hofstede, F. (2015). Een zee van Mosselen. Handboek ecologie, bescherming, beleid en beheer van mosselbanken in de Waddenzee. Lisse, pp. 108

Dijkema KS, G Van Tienen \& JJ Van Beek (1989) Habitats of the Netherlands, German and Danish Wadden Sea 1:100 000. Research Institute for Nature Management, Texel/Veth Foundation, Leiden: 24 maps.

Ende van den D, van Asch M, Troost K, (2014) Het mosselbestand en het areaal aan mosselbanken op de droogvallende platen van de Waddenzee in het voorjaar van 2014. IMARES Rapport C131/14. IMARES Wageningen UR.

Ende van den D, Troost K, van Asch M, Brummelhuis E, Zweeden van C, (2016) Mosselbestand en oesterbanken op droogvallende platen in de Nederlandse kustwater 2016; bestand en arealen. IMARES Rapport C109/16. IMARES Wageningen UR.

Ens BJ \& Alting D (1996) The effect of an experimentally created mussel bed on bird densities and food intake of the Oystercatcher Haematopus ostralegus. Ardea, 84A, 493-507.

Fey F; Dankers N; Meijboom A; Leeuwen van PW; Verdaat H; Jong de M; Dijkman E; Cremer J (2007) Ontwikkeling van mosselbanken in de Nederlandse Waddenzee; situatie 2006. IMARES-rapport 07.006. IMARES Wageningen UR, Texel

Fey F; Dankers N; Meijboom A; Leeuwen van PW; Verdaat H; Jong de M; Heusinkveld, J; Dijkman E; Cremer J (2008) Ontwikkeling van mosselbanken in de Nederlandse Waddenzee; situatie 2007. IMARES-rapport C005/08. IMARES Wageningen UR, Texel 
Fey F; Dankers N; Meijboom A; Leeuwen van PW; Verdaat H; Jong de M; Heusinkveld, J; Dijkman E; Cremer J (2009) Ontwikkeling van mosselbanken in de Nederlandse Waddenzee; situatie 2008. IMARES-rapport C047/09. IMARES Wageningen UR, Texel

Fey-Hofstede FE; Dankers NMJA; Meijboom A; Leeuwen PW van; Jong ML de; Dijkma, EM; Cremer JSM (2010) Ontwikkeling van enkele mosselbanken in de Nederlandse Waddenzee; situatie 2009.IMARESrappoprt C085/10. IMARES Wageningen UR, Texel

Fey-Hofstede FE; Dankers NMJA; Meijboom A; Leeuwen PW van; Jong ML de; Dijkman EM; Cremer JSM (2011) Ontwikkeling van enkele mosselbanken in de Nederlandse Waddenzee; situatie 2010. IMARESrapport C101/11. IMARES Wageningen UR, Texel.

Fey-Hofstede, FE; Dankers, NMJA; Meijboom, A; Leeuwen, PW van; Jong, ML de; Dijkman, EM; Cremer, JSM (2013) Ontwikkeling van enkele mosselbanken in de Nederlandse Waddenzee; situatie 2011 en 2012. IMARES-rapport C128/13. IMARES Wageningen UR, Texel

Fey F.E., N.M.A.J. Dankers, A. Meijboom, P.W. van Leeuwen, M. de Jong, E.M. Dijkman \& J.S.M. Cremer (2014). Ontwikkeling van enkele mosselbanken in de Nederlandse Waddenzee, situatie 2013. WOttechnical report 20/ IMARES Rapport C159/14. WOT Natuur \& Milieu Wageningen UR, Wageningen/ IMARES Wageningen UR, Texel.

Gutiérrez J.L., C.G. Jones, D.L. Strayer, O.O. Iribarne (2003) Mollusks as ecosystem engineers: the role of shell production in aquatic habitats. Oikos 101: 79-90.

Günther CP (1996) Development of small Mytilus beds and its effects on resident intertidal macrofauna. Mar Ecol 17(1-3):117-130.

Koppel van de J, Rietkerk M, Dankers D. \& Herman PMJ (2005) Scale-dependent feedback and regular spatial patterns in young mussel beds. The American Naturalist 165:E66-E77

Markert, A. A. Wehrmann, I. Kröncke (2010) Recently established Crassostrea-reefs versus native Mytilusbeds: differences in ecosystem engineering affects the macrofaunal communities (Wadden Sea of Lower Saxony, southern German Bight). Biological Invasions, 12:15-32.

Ministerie van LNV (2004) Ruimte voor zilte oogst. Naar een omslag in de Nederlandse schelpdiercultuur. Beleidsbesluit Schelpdiervisserij 2005-2020.in N. e. V. Ministerie van Landbouw, editor., Den Haag.

Ministerie van LNV (2008) Profieldocument H1140 december NB-wet Natura 2000. http://www.synbiosys.alterra.nl/natura2000/documenten/profielen/habitattypen/profiel_habitattype_1140.pdf

Ministerie van Infrastructuur en Milieu (2016) Natura 2000-beheerplan Waddenzee, periode 2016 - 2022. pp 331.

Nehls G., I. Hertzler, G. Scheiffarth (1997) Stable mussel Mytilus edulis beds in the Wadden Sea: they're just for the birds. Helgolander Meeresuntersuchungen 51:361-72.

Petersen, J.K., M. Maar, F. Mohlenberg and J.E. (2012) Benthic grazing impact: Coupling and uncoupling in relation to physical foricng. Marine Ecology Progress Series 463: 127-139.

Prins, T.C., A.C. Smaal and R.F. Dame (1998) A review of the feedbacks between bivalve grazing and ecosystem processes. Aquatic Ecology 31: 349-359.

Prins, T.C. \& V. Escaravage (2005) Can bivalve suspension feeders affect pelagic food web structure? In: The Comparative Roles of Suspension Feeders in Ecosystems. R.F. Dame and S. Olenin. Dordrecht Springer: 31-51.

Steenbergen J, JMDD Baars, MR van Stralen, J Kesteloo-Hendrikse \& TP Bult (2003) Het mosselareaal en bestand op de droogvallende platen in de Waddenzee in het voorjaar van 2003. RIVO-rapport C070/03. RIVO, IJmuiden.

Tsuchiya M, Nishihira M (1985) Islands of Mytilus as a habitat for small intertidal animals: effect of island size on community structure. Mar Ecol Prog Ser 25:71-81

Tsuchiya M, Nishihira M (1986) Islands of Mytilus edulis as a habitat for small intertidal animals: effect of Mytilus age structure on the species composition of the associated fauna and community organization. Mar Ecol Prog Ser 31:171-187

Tydeman, P (1996) Ecologisch profiel van de wilde litorale mosselbank (Mytilus edulis L.). Rapport RIKZ 96.026. RIKZ, Den Haag.

Zwarts L, (1991) Mosselbanken: wadvogels op een kluitje. Vogels 66: 8-12. 


\section{Verantwoording}

Dit rapport is met grote zorgvuldigheid tot stand gekomen. De wetenschappelijke kwaliteit is intern bij Wageningen Marine Research (WMR) getoetst door Karin Troost, collega-onderzoeker en Jacob Asjes als verantwoordelijk lid van het managementteam van WMR. 



\section{Bijlage 1 Monsterpunten}

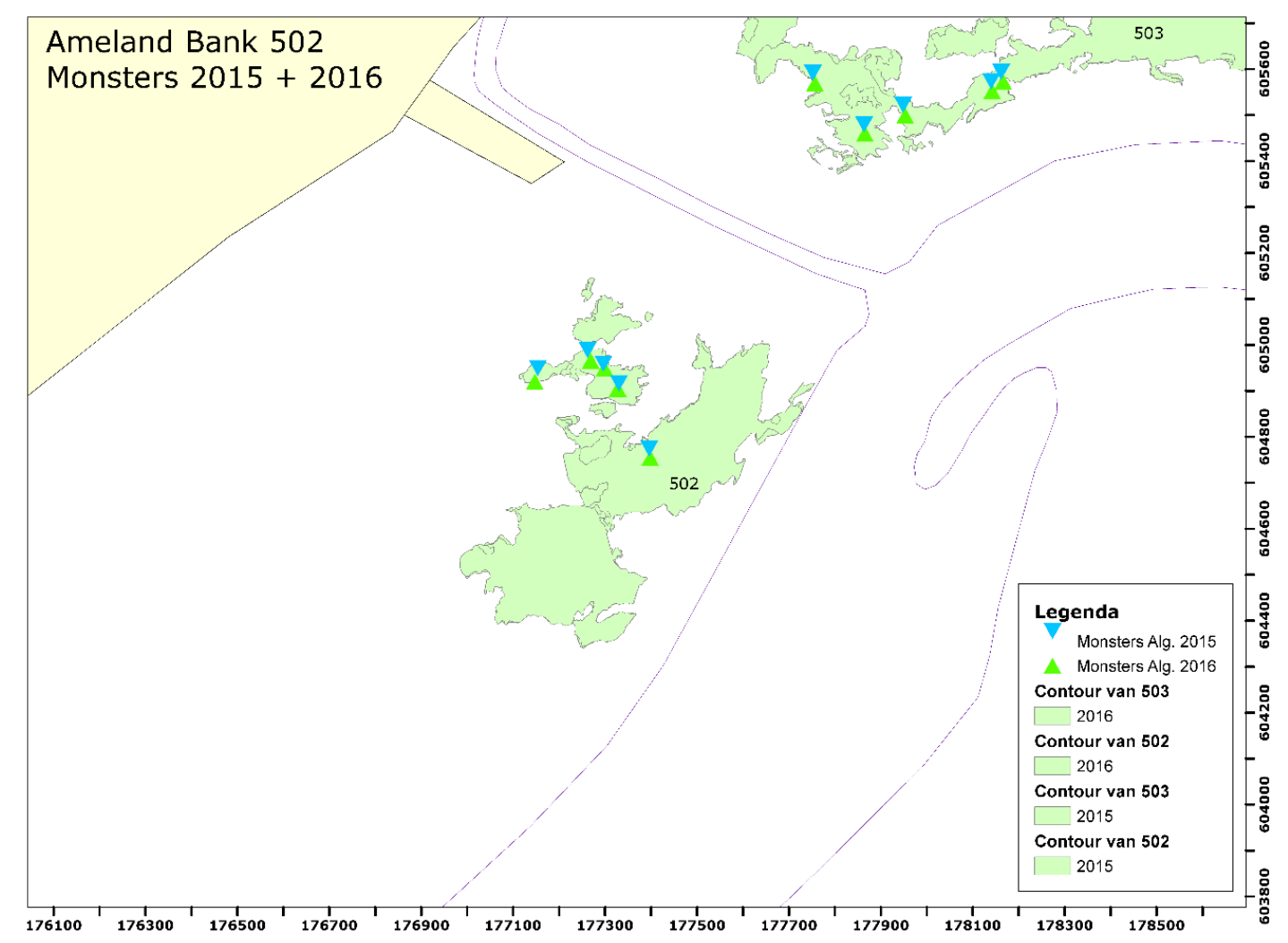

Figuur B1.1 Locaties van de vierkantmonsters op mosselbank 502 in 2015 en 2016.

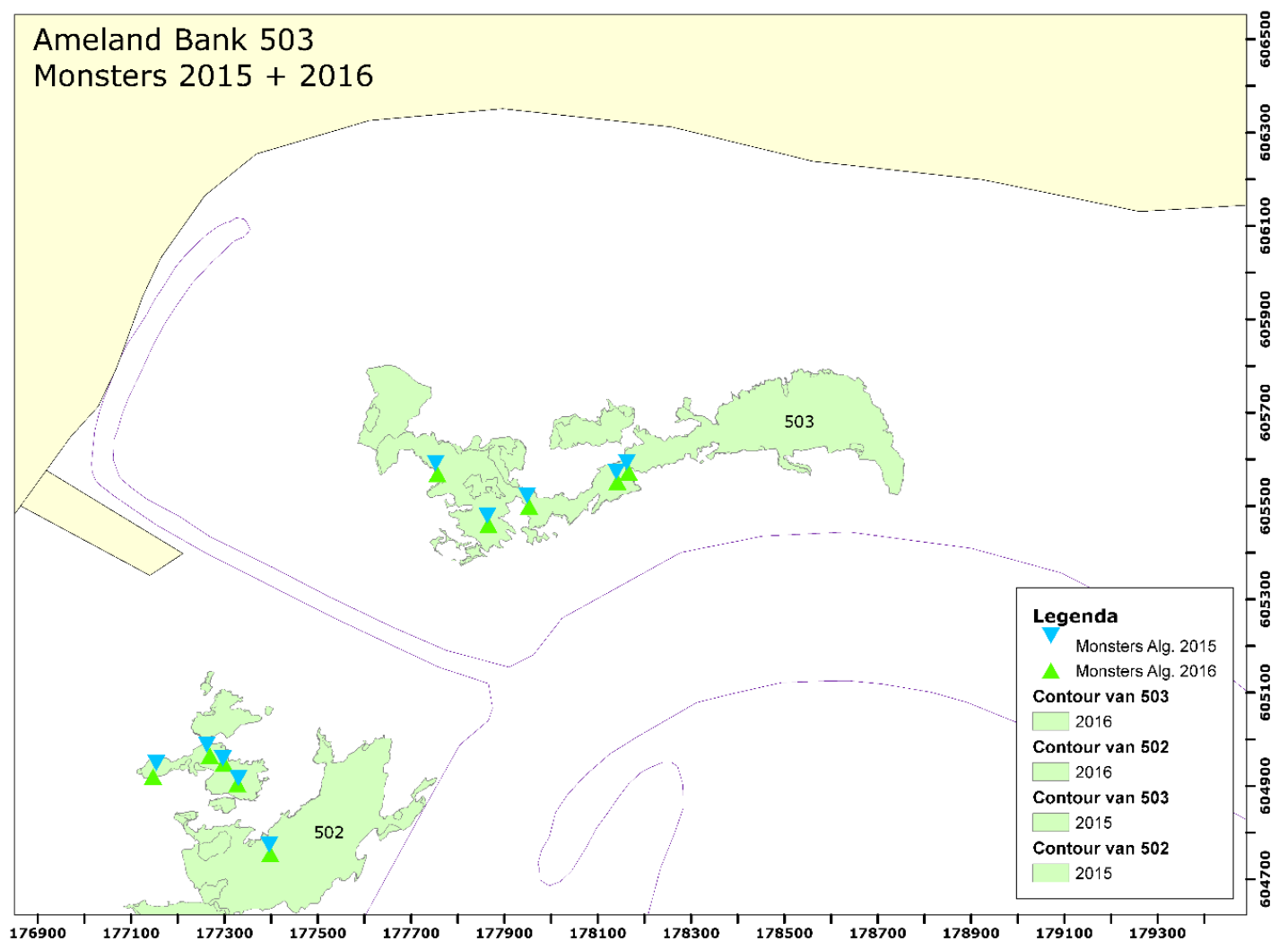

Figuur B.1.2 Locaties van de vierkantmonsters op mosselbank 503 in 2015 en 2016. 


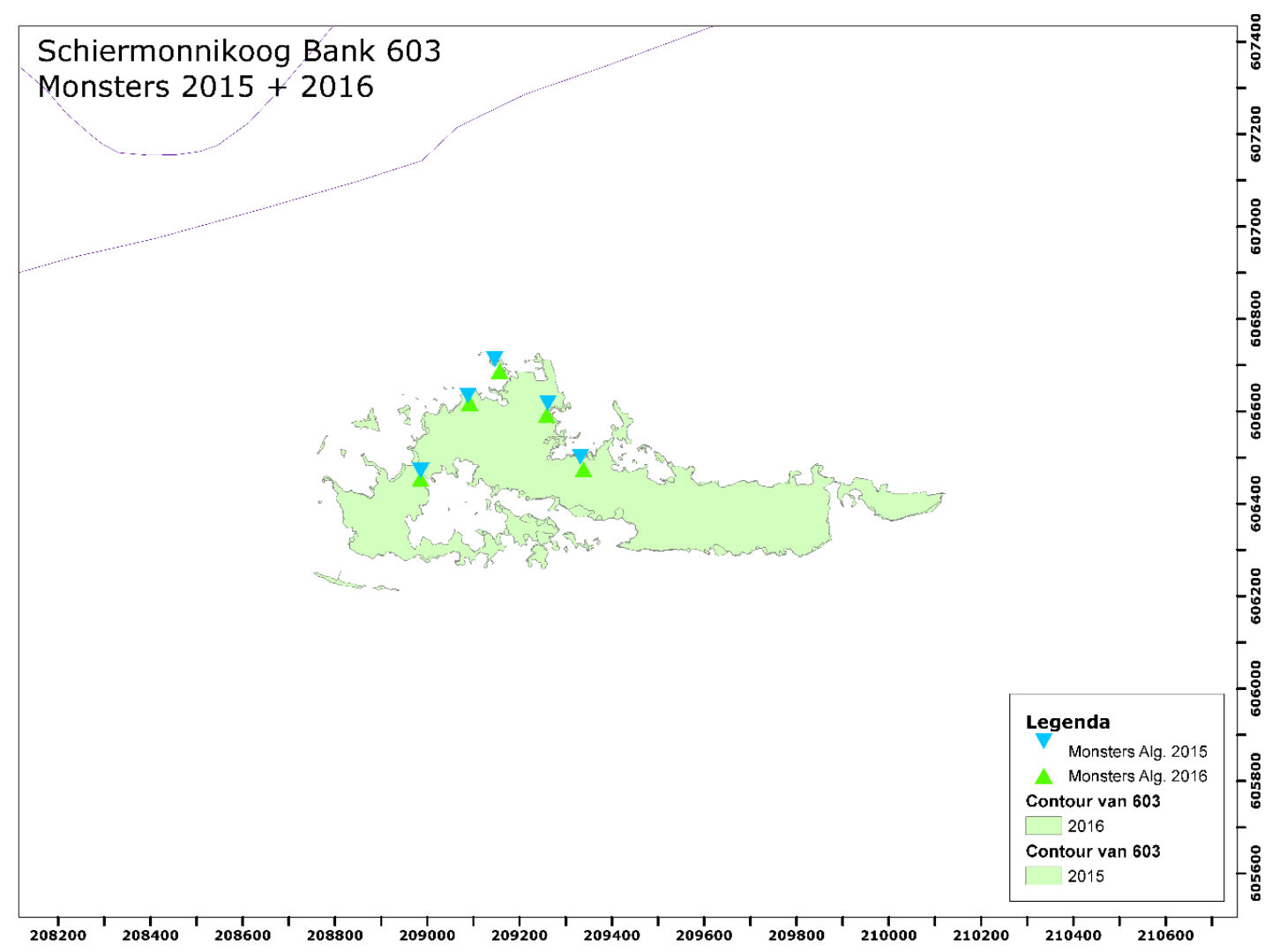

Figuur B1.3 Locaties van de vierkantmonsters op mosselbank 603 in 2015 en 2016.

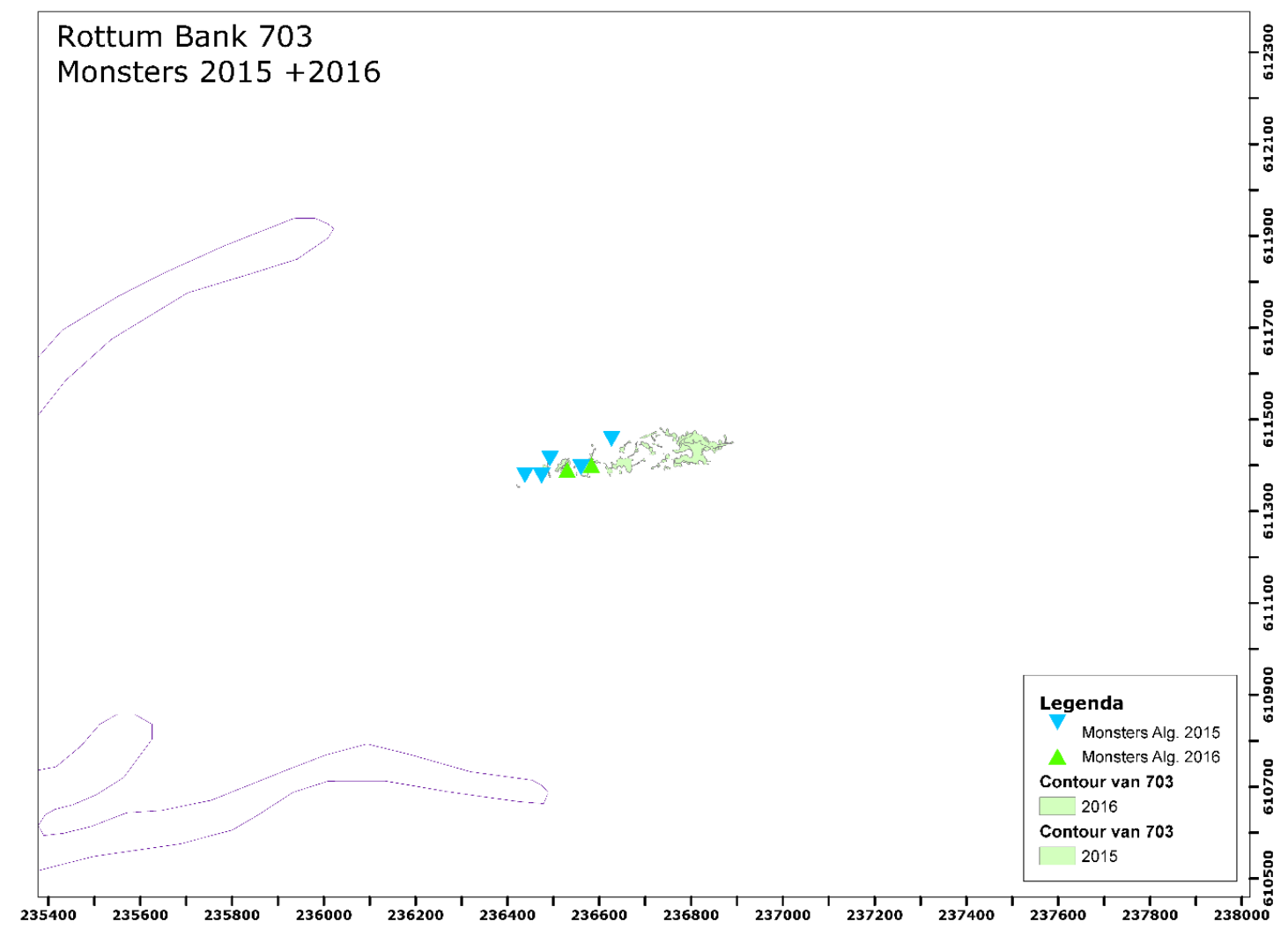

Figuur B1.4 Locaties van de vierkantmonsters op mosselbank 703 in 2015 en 2016. 


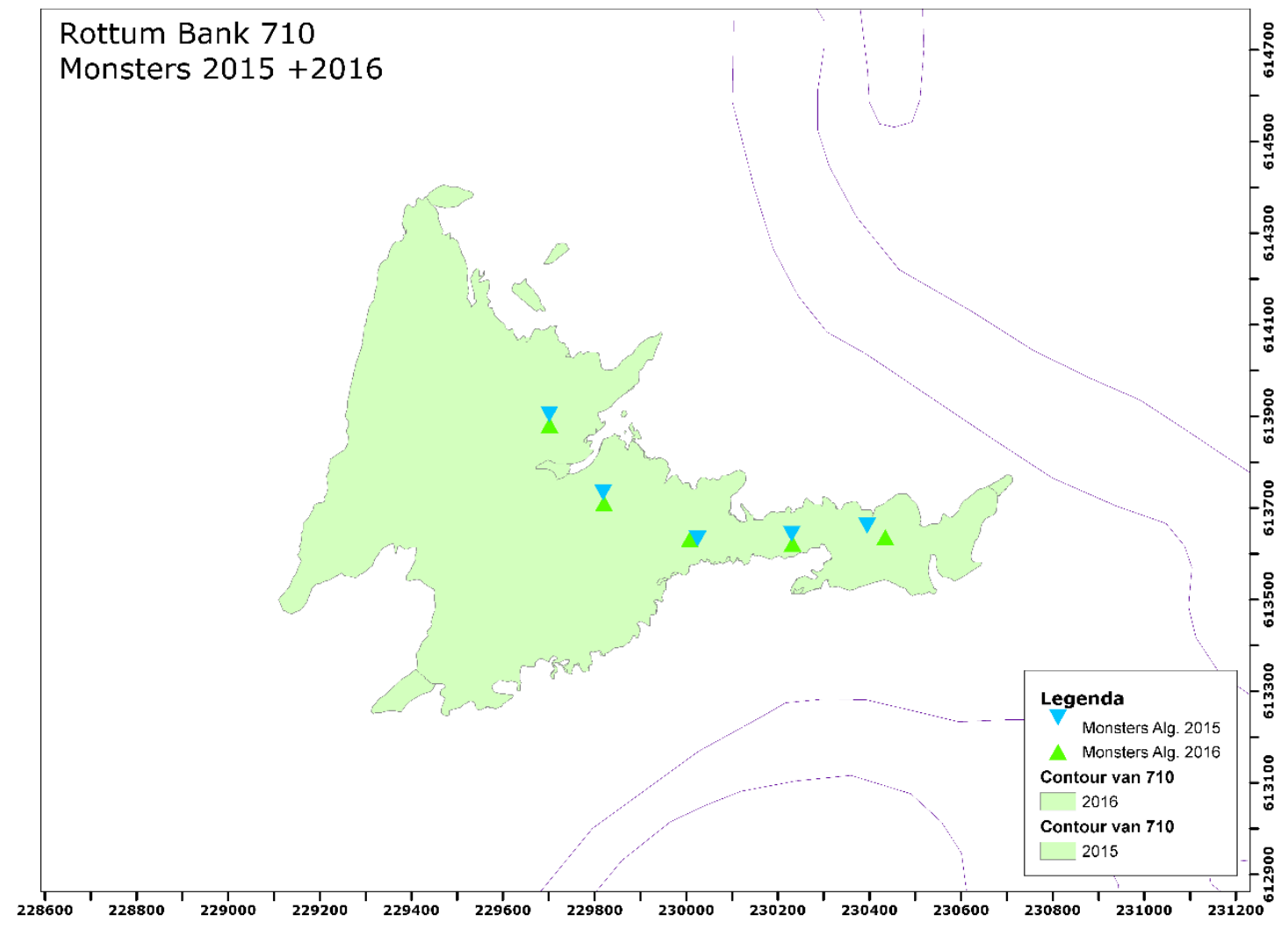

Figuur B1.5 Locaties van de vierkantmonsters op mosselbank 710 in 2015 en 2016.

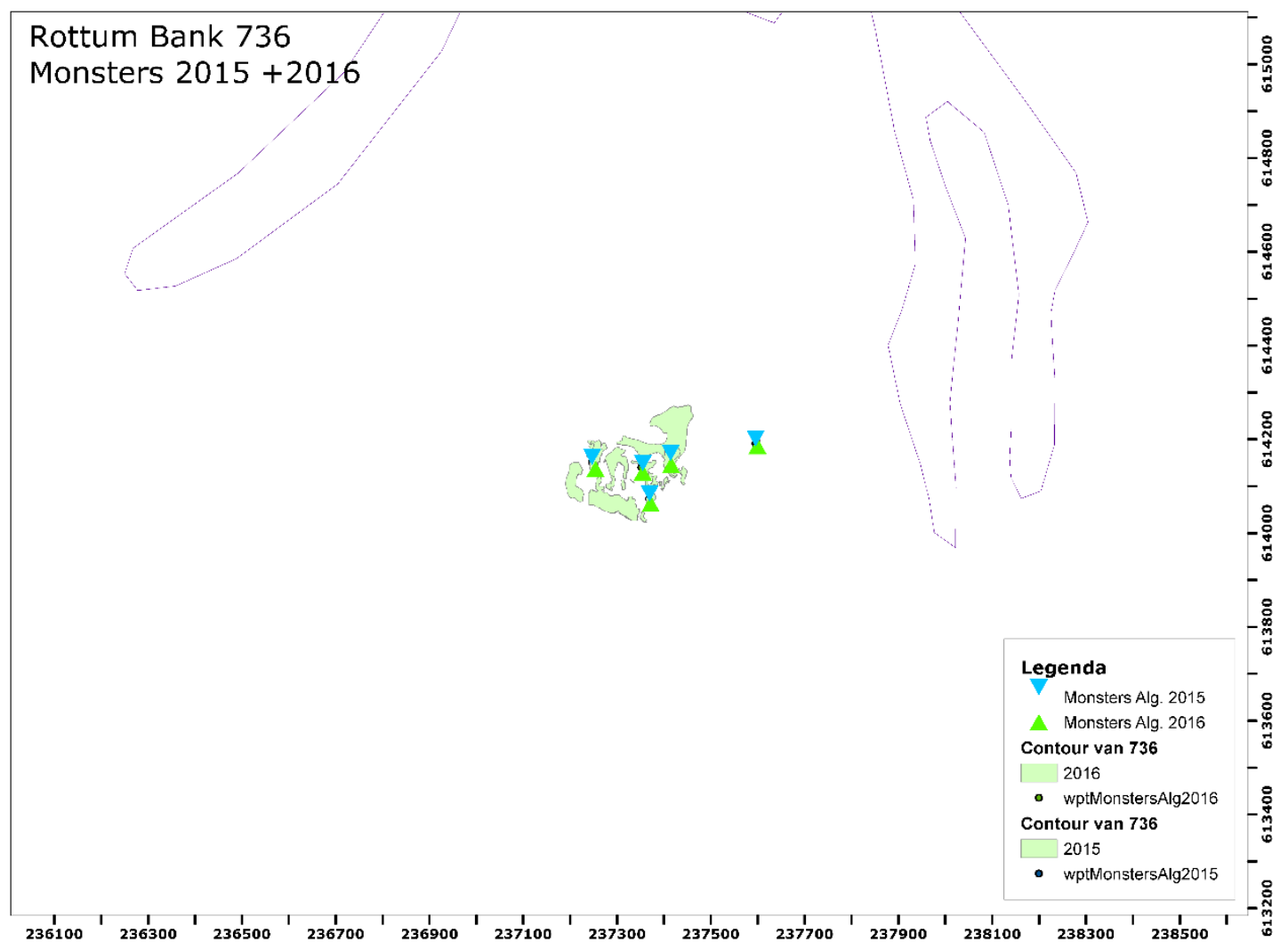

Figuur B1.6 Locaties van de vierkantmonsters op mosselbank 736 in 2015 en 2016. 



\section{Bijlage 2 Bedekking mosselbanken}

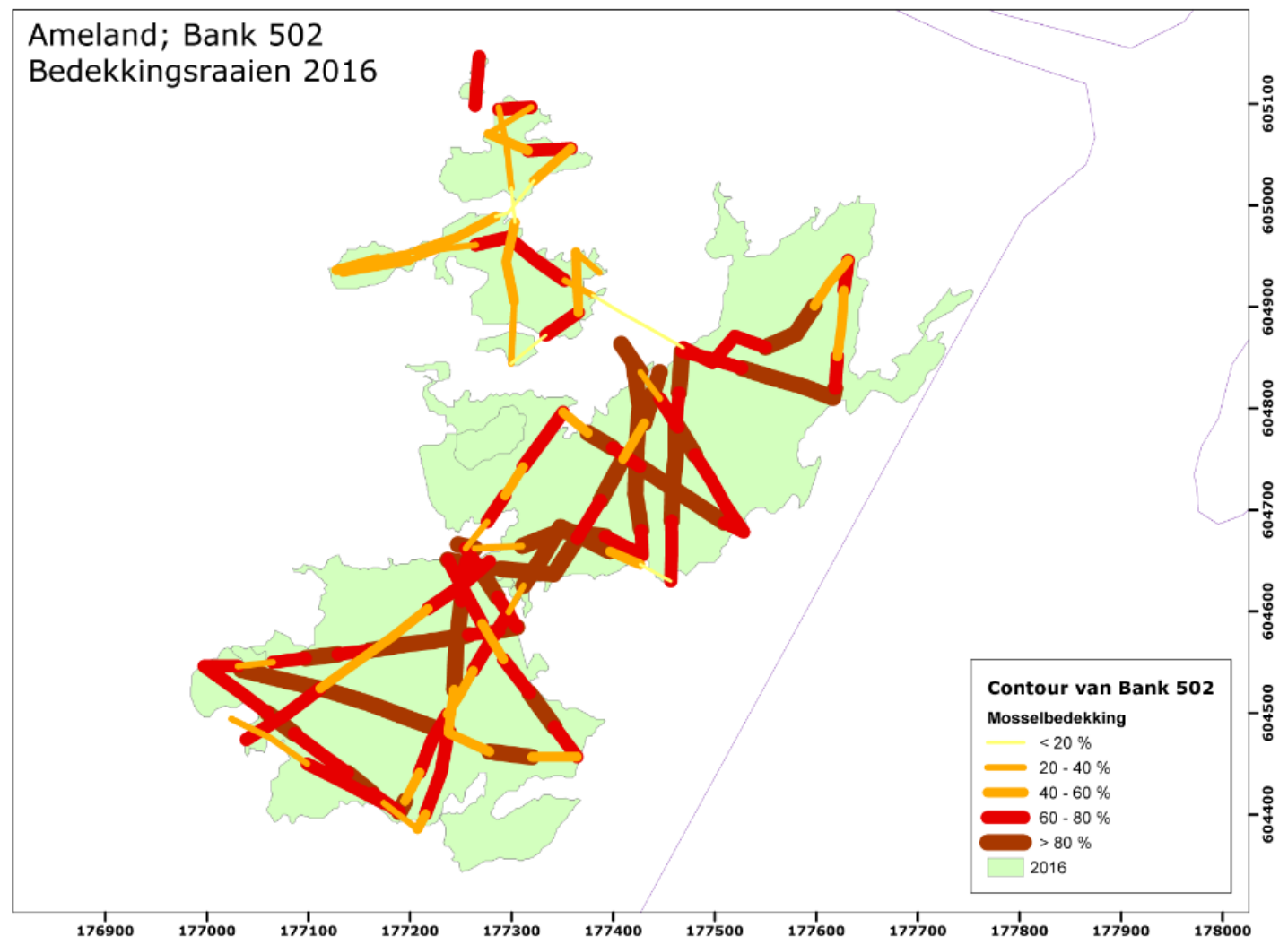

Figuur B2.1 Mosselbedekking op de subraaien op mosselbank 502 in 2016.

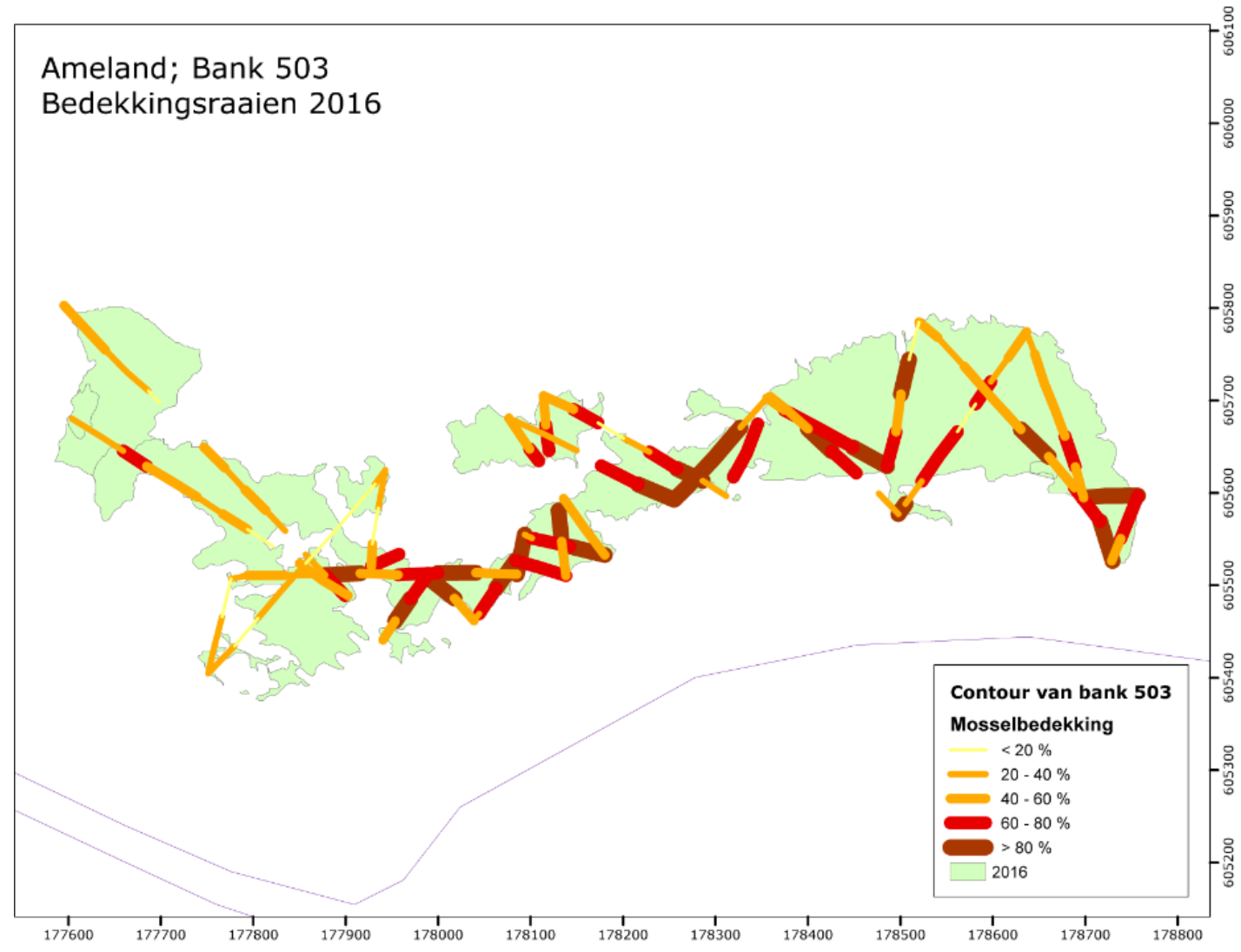

Figuur B2.2 Mosselbedekking op de subraaien op mosselbank 503 in 2016. 
Brakzand Schiermonnikoog; Bank 603

Bedekkingsraaien 2016

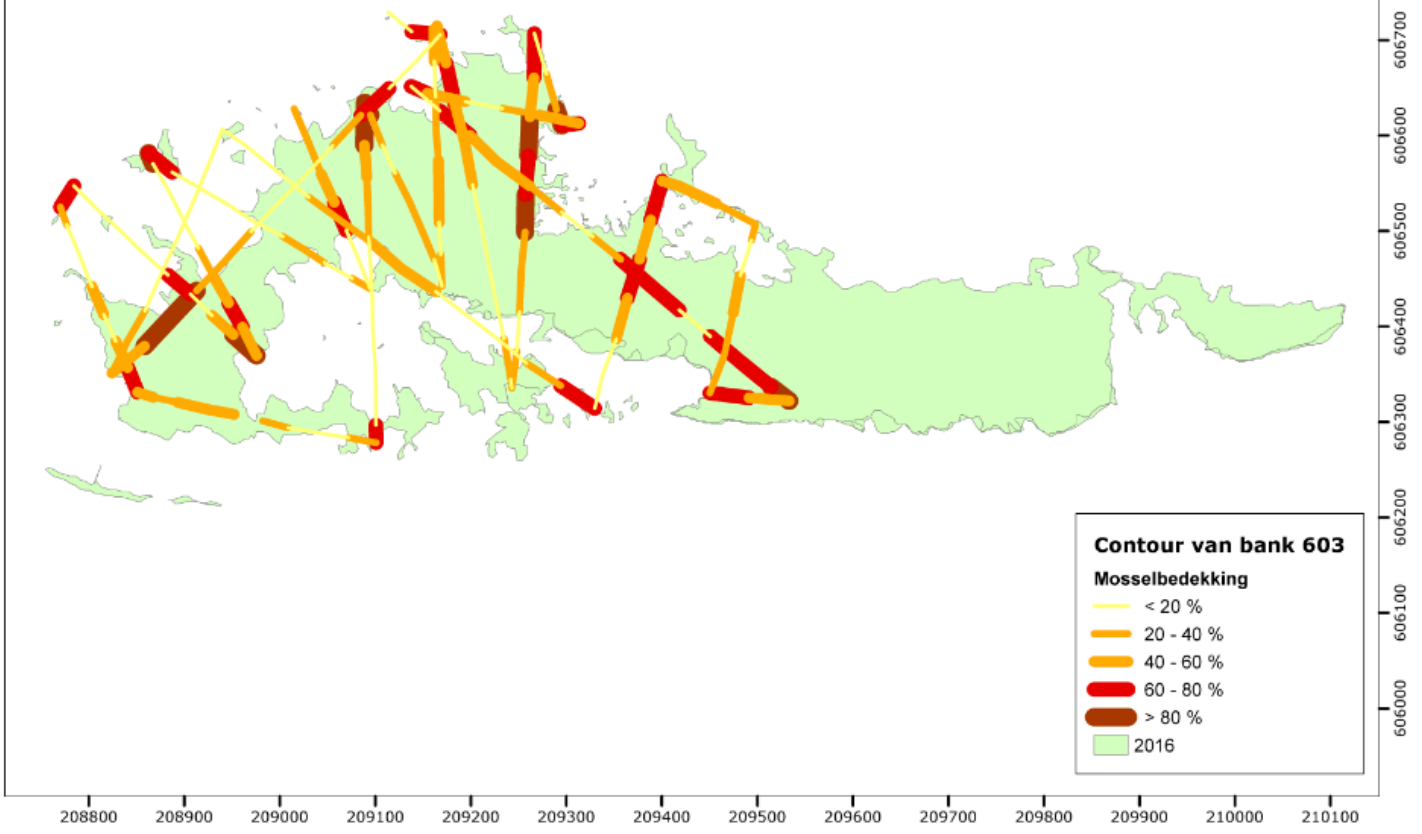

Figuur B2.3 Mosselbedekking op de subraaien op mosselbank 603 in 2016.

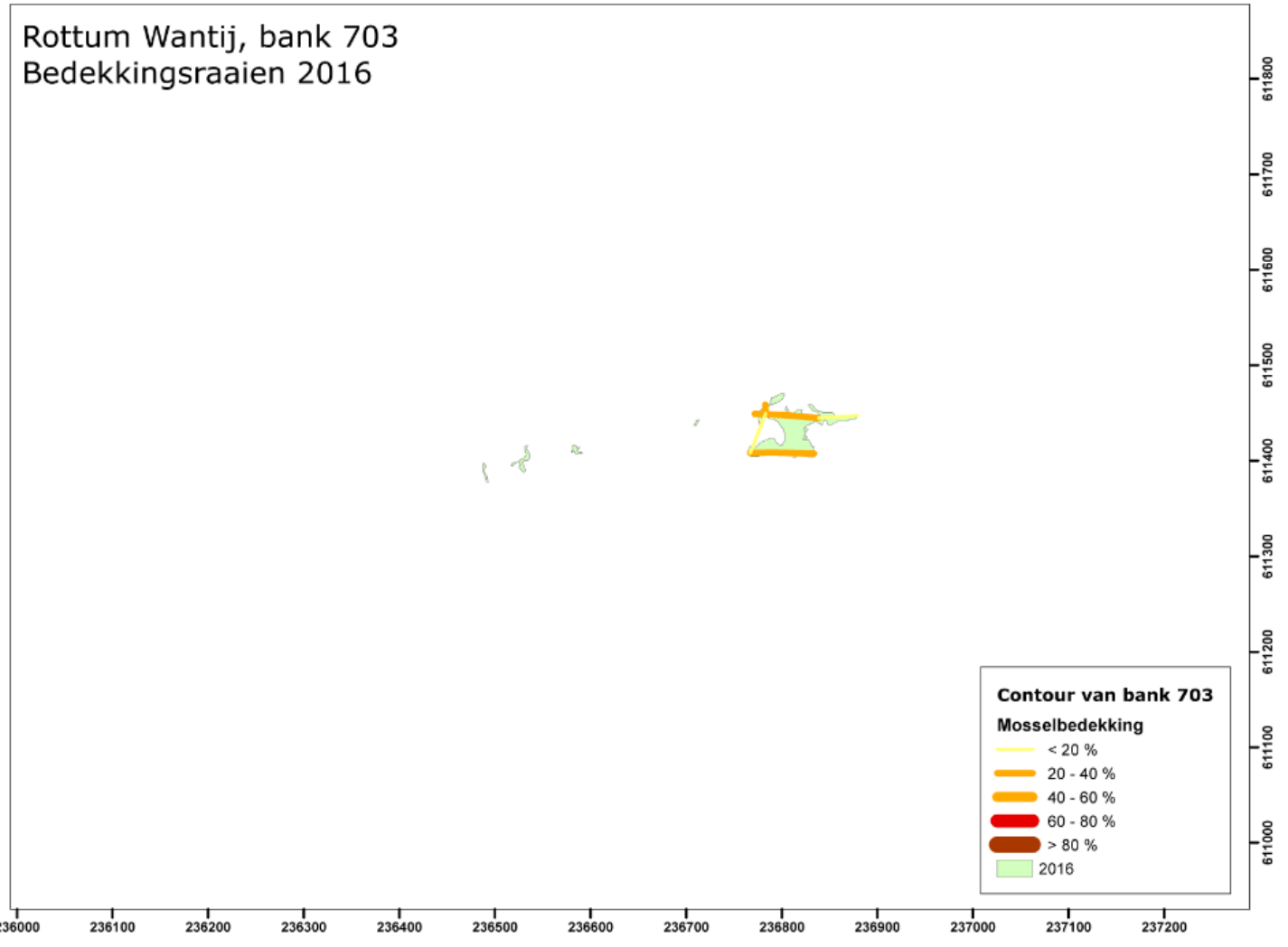

Figuur B2.4 Mosselbedekking op de subraaien op mosselbank 703 in 2016. 


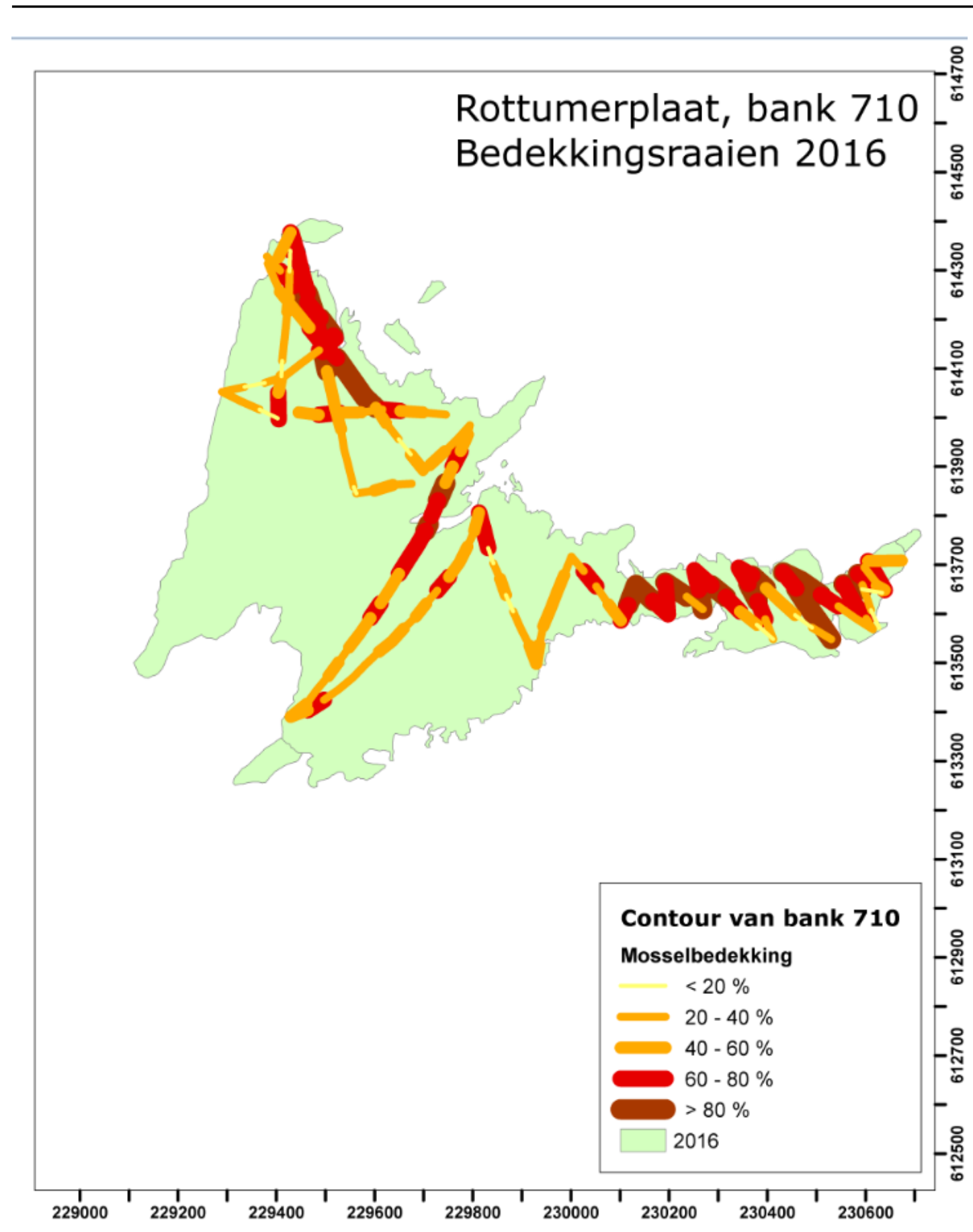

Figuur B2.5 Mosselbedekking op de subraaien op mosselbank 710 in 2016. 


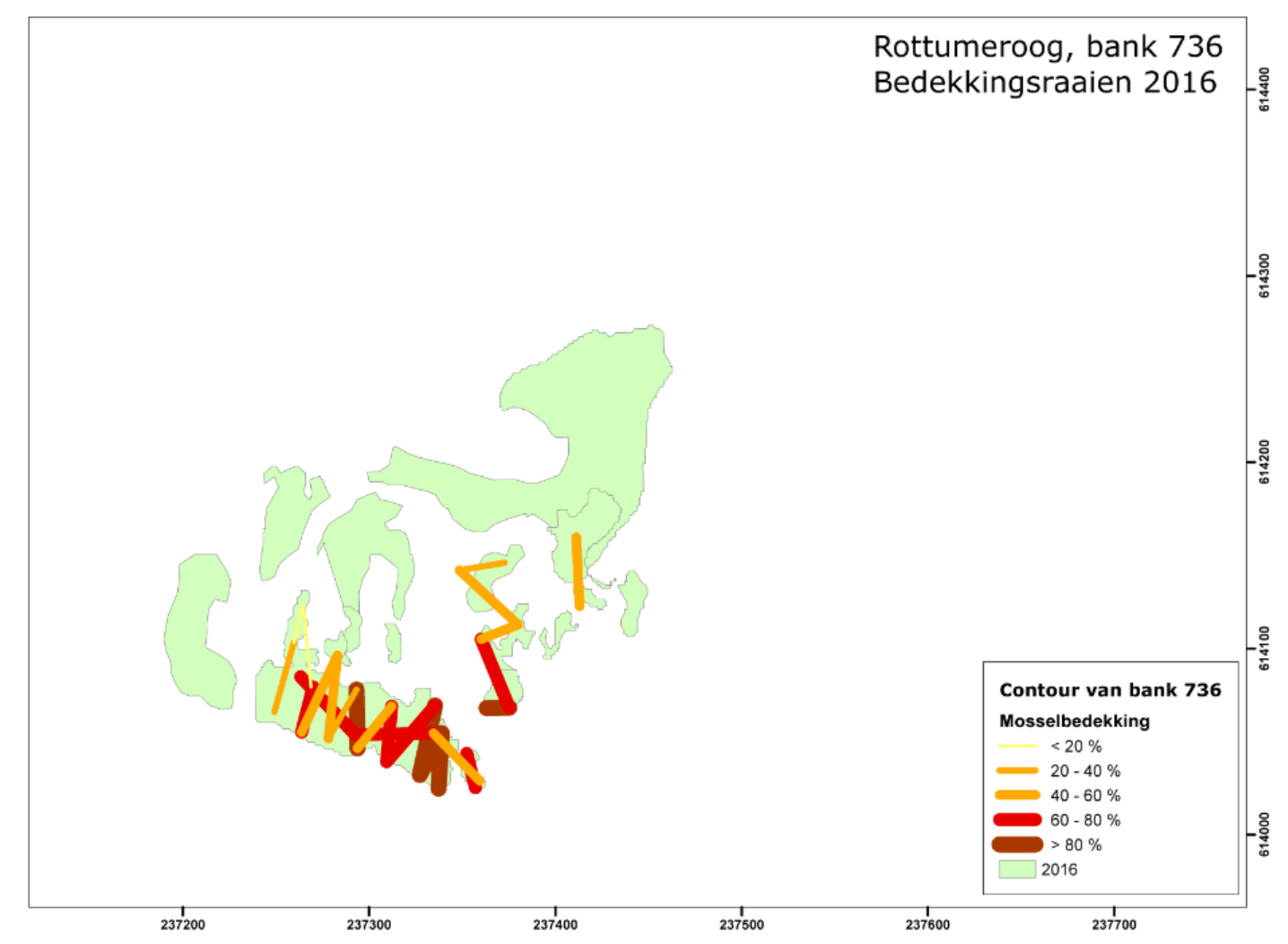

Figuur B2.6 Mosselbedekking op de subraaien op mosselbank 736 in 2016. 


\section{Bijlage 3 Oesterbedekking mosselbanken}

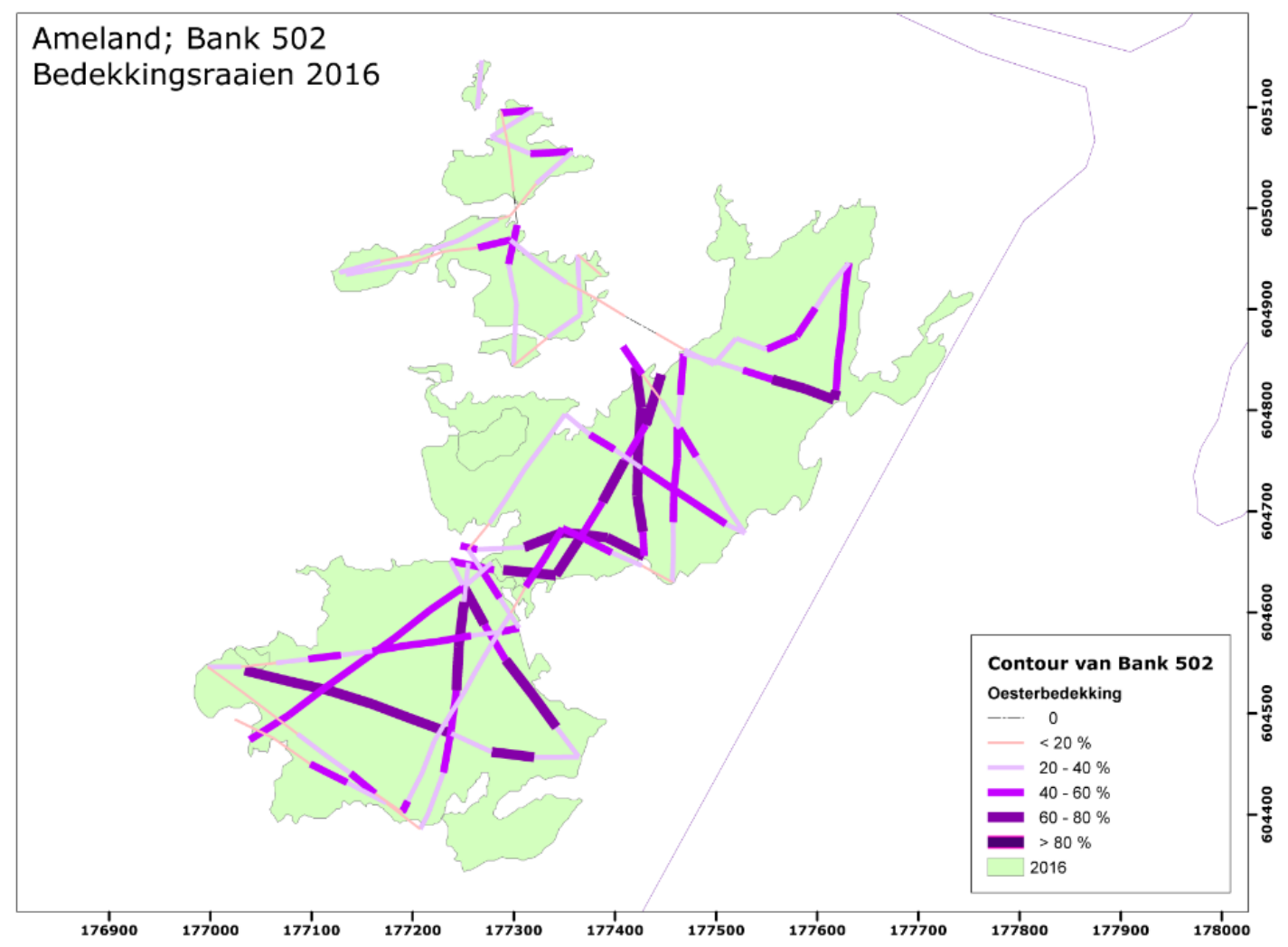

Figuur B3.1 Oesterbedekking op de subraaien op mosselbank 502 in 2016.

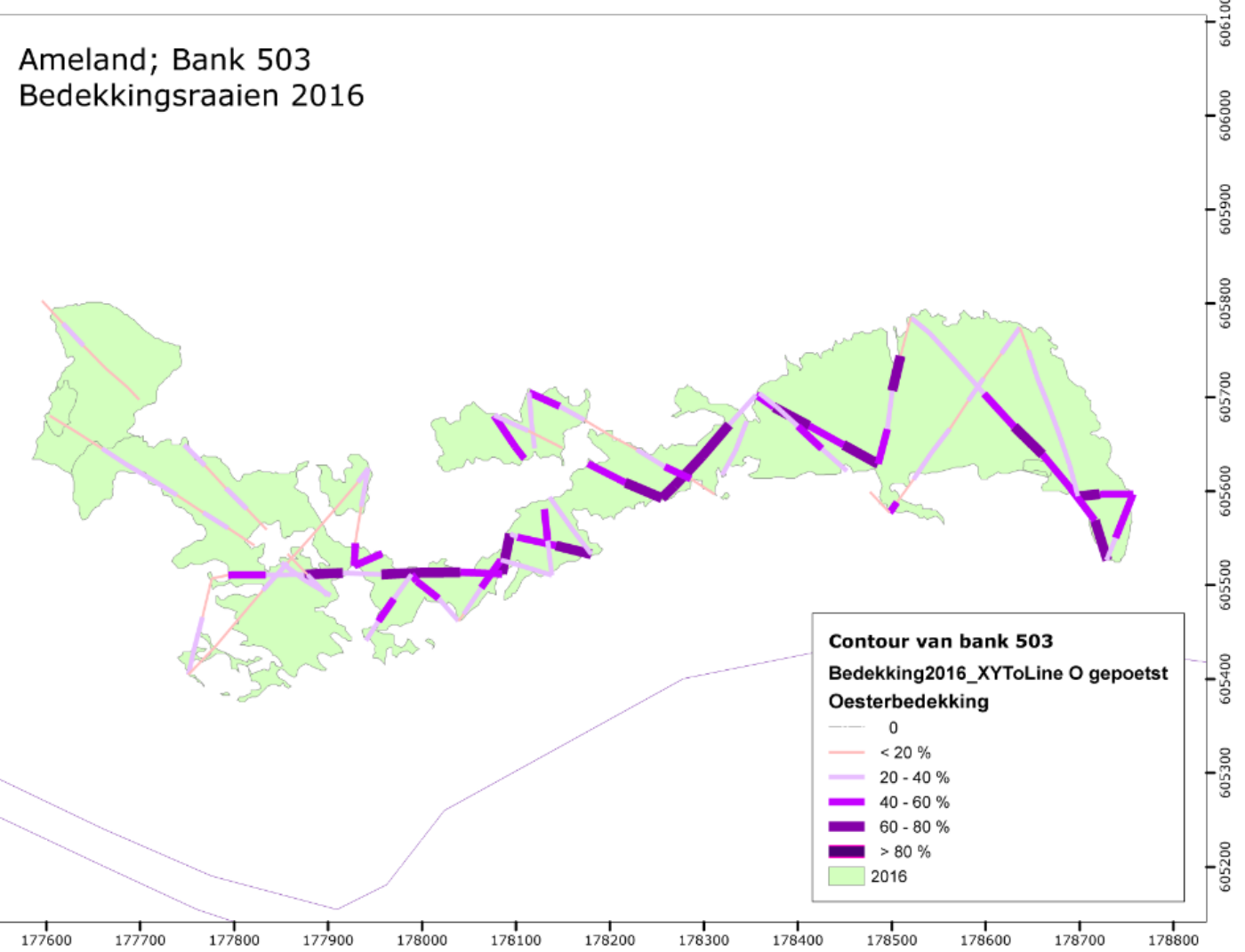

Figuur B3.2 Oesterbedekking op de subraaien op mosselbank 503 in 2016. 
Brakzand Schiermonnikoog; Bank 603

Bedekkingsraaien 2016

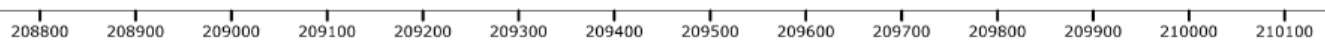

Figuur B3.3 Oesterbedekking op de subraaien op mosselbank 603 in 2016.

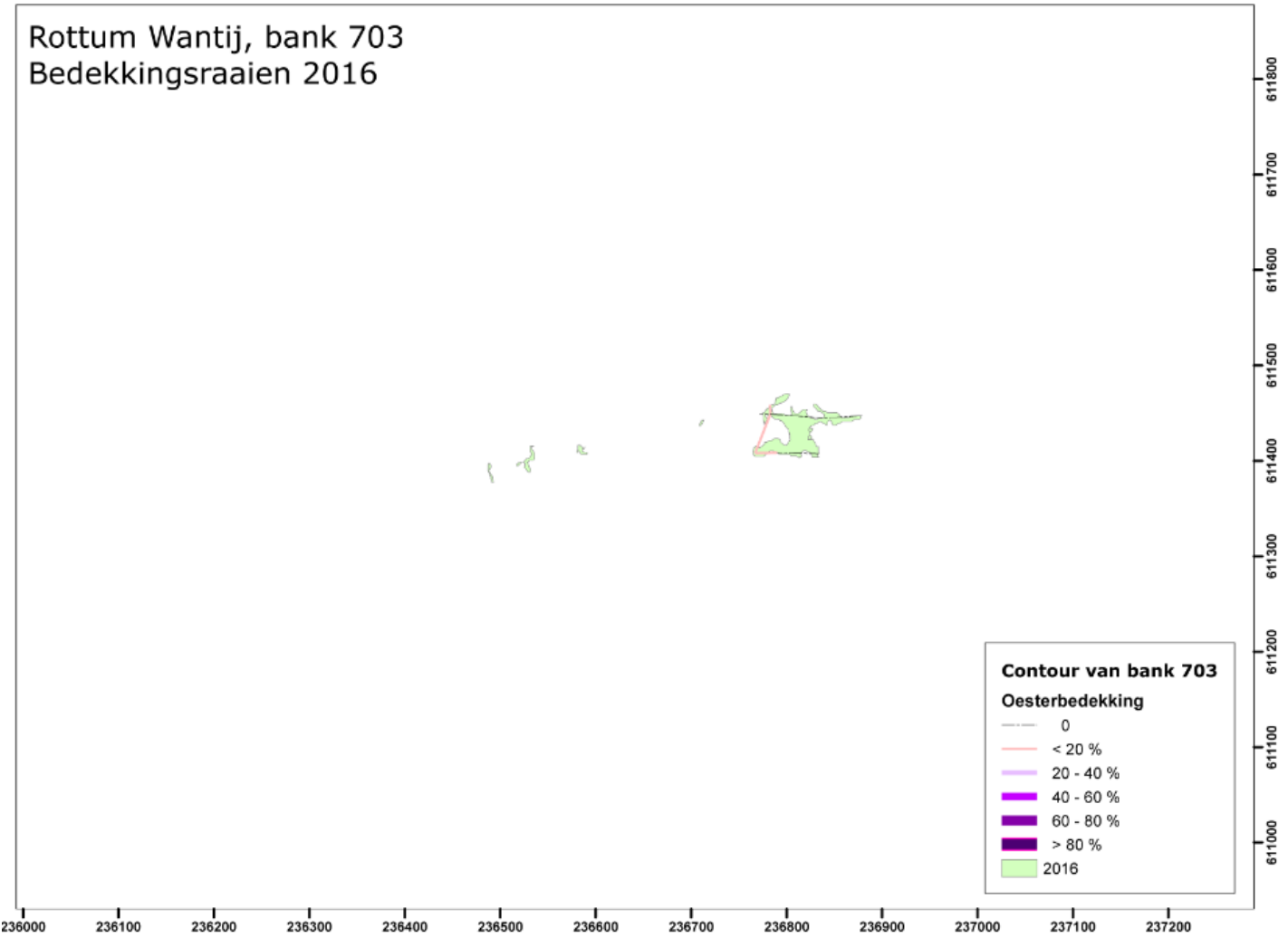

Figuur B3.4 Oesterbedekking op de subraaien op mosselbank 703 in 2016 


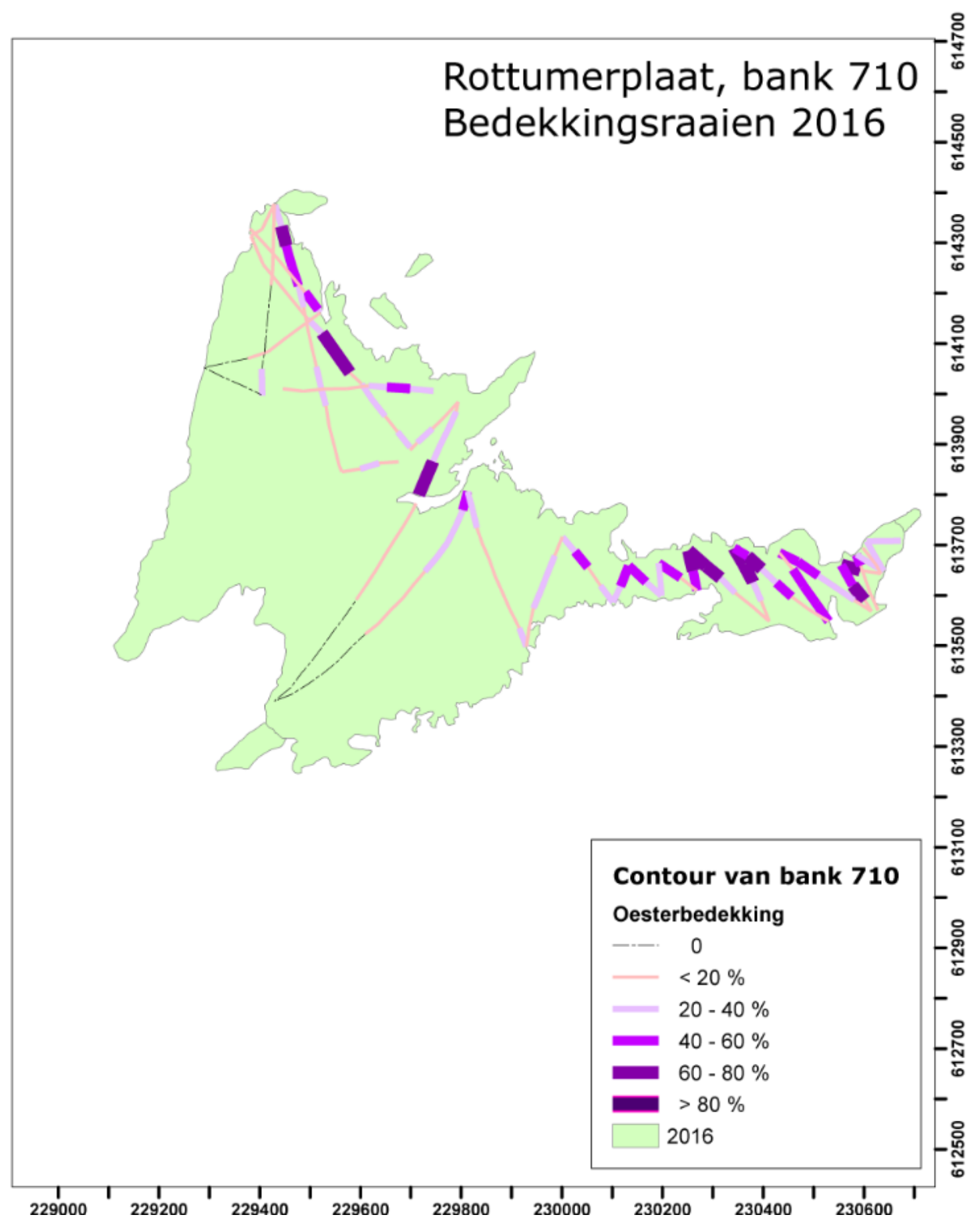

Figuur B3.5 Oesterbedekking op de subraaien op mosselbank 710 in 2016. 


\section{Ontwikkeling oesterpopulatie}

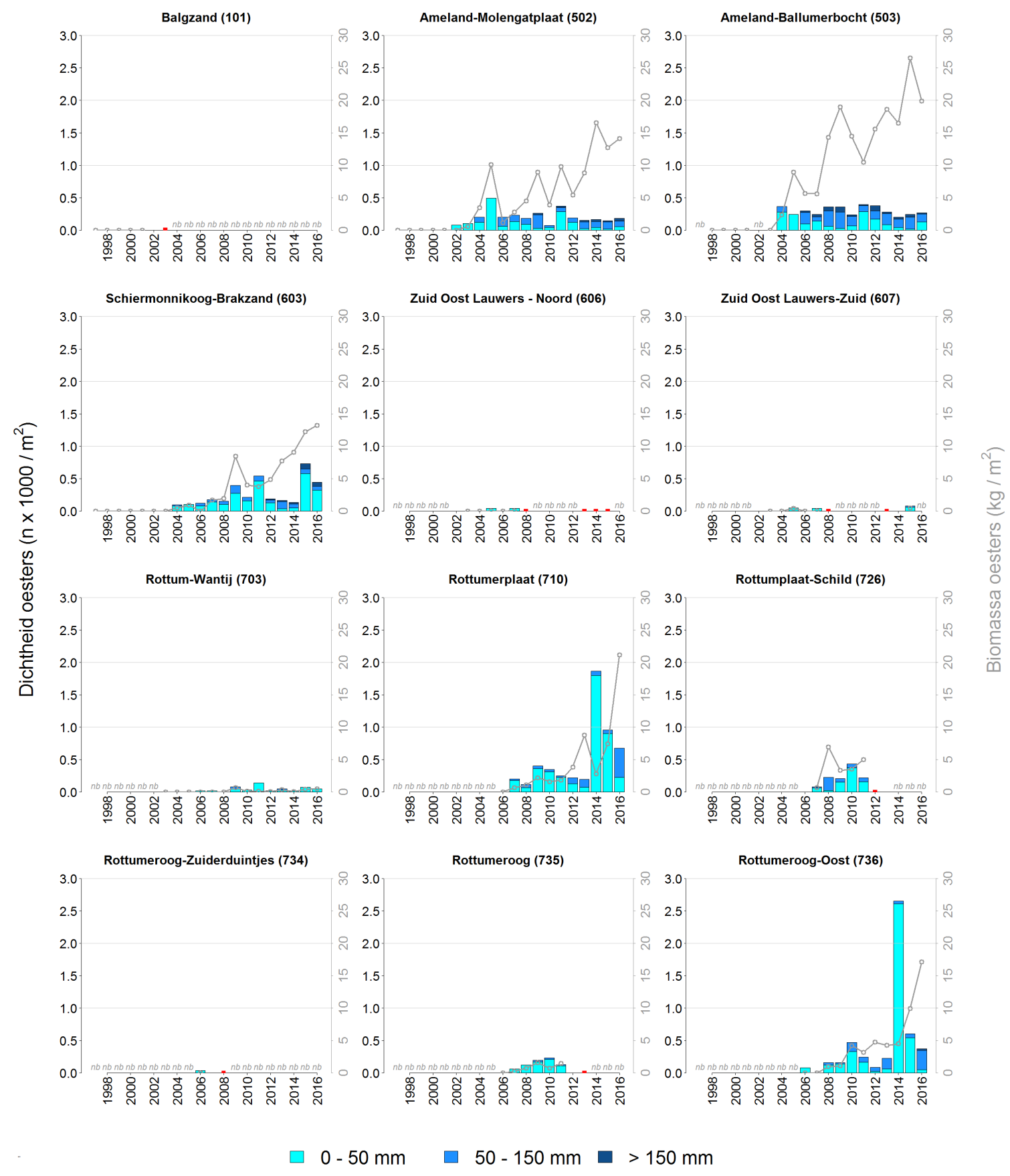

Figuur B3.6 Ontwikkeling van jaargemiddelde dichtheid $\left(n \times 1000 / \mathrm{m}^{2}\right)$ en biomassa $(\mathrm{kg}$ natgewicht $\left./ \mathrm{m}^{2}\right)$ Japanse oesters zoals aangetroffen in de vierkantmonsters $\left(1 / 20 \mathrm{~m}^{2}\right)$ voor de banken 101, 502, 503, 603, 606, 607, 703, 710, 726, 734, 735 en 736 in de periode $1997 \mathrm{t} / \mathrm{m} 2016$ (of tot wanneer ze bezocht zijn/ aanwezig waren). Wanneer een bank wel bezocht werd maar deze niet aanwezig was is dit met een rode stip aangegeven 


\section{Verschenen documenten in de reeks Technical reports van de Wettelijke Onderzoekstaken Natuur}

\& Milieu vanaf 2016

WOt-technical reports zijn verkrijgbaar bij het secretariaat van Unit Wettelijke Onderzoekstaken Natuur \& Milieu te Wageningen. T 0317 - 4854 71; E info.wnm@wur.nl

WOt-technical reports zijn ook te downloaden via de website www.wur.nl/wotnatuurenmilieu.

61 Berg, F. van den, A. Tiktak, J.J.T.I. Boesten \& A.M.A. van der Linden (2016). PEARL model for pesticide behaviour and emissions in soil-plant systems, Description of processes

62 Kuiters, A.T., G.A. de Groot, D.R. Lammertsma, H.A.H. Jansman \& J. Bovenschen (2016). Genetische monitoring van de Nederlandse otterpopulatie; Ontwikkeling van populatieomvang en genetische status 2014/2015

63 Smits, M.J.W., C.M. van der Heide, H. Dagevos, T. Selnes \& C.M. Goossen (2016). Natuurinclusief ondernemen: van koplopers naar mainstreaming?

64 Pouwels, P. , M. van Eupen, M.H.C. van Adrichem, B. de Knegt \& J.G.M. van der Greft (2016). MetaNatuurplanner v2.0. Status A

65 Broekmeyer, M.E.A. \& M.E. Sanders (2016). Natuurwetgeving en het omgevingsrecht. Achtergrond-document bij Balans van de Leefomgeving, 2014

66 Os, J. van, J. H.S.D. Naeff \& L.J.J. Jeurissen (2016).Geografisch informatiesysteem voor de emissieregistratie van landbouwbedrijven; GIABplus-bestand 2013 - Status A

67 Ingram, V.J., L.O. Judge, M. Luskova, S. van Berkum \& J. van den Berg (2016). Upscaling sustainability initiatives in international commodity chains; Examples from cocoa, coffee and soy value chains in the Netherlands.

68 Duin van W.E., H. Jongerius, A. Nicolai, J.J. Jongsma A. Hendriks \& C. Sonneveld (2016). Friese en Groninger kwelderwerken: Monitoring en beheer 1960-2014.

69 Ehlert, P.A.I., T.A. van Dijk \& O. Oenema (2016). Opname van struviet als categorie in het Uitvoeringsbes/uit Meststoffenwet. Advies.

70 Ehlert, P.A.I., H.J. van Wijnen, J. Struijs, T.A. van Dijk, L. van Schöll, L.R.M. de Poorter (2016) Risicobeoordeling van contaminanten in afval- en reststoffen bestemd voor gebruik als covergistingsmateriaal

71 Commissie Deskundigen Meststoffenwet (2016). Protocol beoordeling stoffen Meststoffenwet. Versie 3.2

72 Kramer, H., J. Clement (2016). Basiskaart Natuur 2009. Een landsdekkend basisbestand voor de terrestrische natuur in Nederland

73 Dam, R.I. van, T.J.M. Mattijssen, J. Vader, A.E. Buijs \& J.L.M. Donders (2016). De betekenis van groene zelf-governance. Analyse van verschillende vormen van dynamiek in de praktijk.
74 Hennekens, S.M., M. Boss \& A.M. Schmidt (2016). Landelijke Vegetatie Databank; Technische documentatie, Status A

75 Knegt, B. de, et al. (2016). Kansenkaarten voor duurzaam benutten van Natuurlijk Kapitaal

76 Commissie Deskundigen Meststoffenwet (2016). Advies 'Mestverwerkingspercentages 2017'

77 W.H.J. Beltman, C. Vink \& A. Poot (2016). Calculation of exposure concentrations for NL standard scenarios by the TOXSWA model; Use of FOCUS_TOXSWA 4.4.3 software for plant protection products and their metabolites in Dutch risk assessment for aquatic ecosystems

78 Koffijberg K., J.S.M. Cremer, P. de Boer, J. Postma \& K. Oosterbeek \& J.S.M. Cremer (2016) Broedsucces van kustbroedvogels in de Waddenzee in 2014

79 Sanders, M.E. G.W.W Wamelink, R.M.A. Wegman \& J. Clement (2016). Voortgang realisatie nationaal natuurbeleid; Technische achtergronden van een aantal indicatoren uit de digitale Balans van de Leefomgeving 2016

80 Vries, S. de \& I.G. Staritsky (2016). AVANAR 2.0 nader beschreven en toegelicht; Achtergronddocumentatie voor Status $A$.

81 Kuiters, A.T., G.A. de Groot, D.R. Lammertsma, H.A.H. Jansman \& J. Bovenschen (2016). Genetische monitoring van de Nederlandse otterpopulatie; Ontwikkeling van populatieomvang en genetische status 2015/ 2016.

82 Pleijte, M., R. Beunen \& R. During (2016) Rijksprojecten: hét natuurinclusieve werken? Een analyse van relaties tussen rijksprojecten en de Rijksnatuurvisie

83 Smits, M.J.W. en E.J. Bos (2016). Het stimuleren van ondernemen met natuur: handelingsopties voor de overheid

84 Horst, M.M.S. ter, W.H.J. Beltman \& F. van den Berg (2016). The TOXSWA model version 3.3 for pesticide behaviour in small surface waters; Description of processes

85 Mattijssen, T.J.M. (2016). Ideaaltypen en analysekader van groene burgerinitiatieven; Bijlage bij het rapport 'De betekenis van groene burgerinitiatieven: analyse van kenmerken en effecten van 264 initiatieven in Nederland

86 Wösten, J.H.M., F. de Vries \& J.G. Wesseling (2016). BOFEK2012 versie 2; Status A

87 Pleijte, M., R. During \& R. Michels (2016). Nationale parken in transitie; governance-implicaties van een veranderend beleidskader 
88 Mol-Dijkstra, J.P.\& G.J Reinds (2017). Technical documentation of the soil model VSD+; Status A

89 Arets, E.J.M.M., J.W.H van der Kolk, G.M. Hengeveld, J.P. Lesschen, H. Kramer, P.J. Kuikman \& M.J. Schelhaas (2017). Greenhouse gas reporting for the LULUCF sector in the Netherlands. Methodological background, update 2016

90 Bruggen, C. van, A. Bannink, C.M. Groenestein, J.F.M. Huijsmans, H.H. Luesink, S.V. Oude Voshaar, S.M. van der Sluis, G.L. Velthof \& J. Vonk (2017). Emissies naar lucht uit de landbouw in 2014. Berekeningen met het model NEMA

91 Os van, J., M.G.T.M. Bartholomeus, L.J.J. Jeurissen \& C.G. van Reenen (2017). Rekenregels rundvee voor de landbouwtelling. Verantwoording van het gebruik van I\&R gegevens voor de landbouwtelling

92 Haas, W. de, R.J. Fontein \& M. Pleijte (2017). Is eenvoudig beter? Twee essays natuur en landschap in het nieuwe omgevingsbeleid

93 Schuiling, C., A.M. Schmidt, I.J. La Rivière \& R.A. Smidt (2017). Beschermde gebiedenregister; Technische documentatie, Status A.

94 Henkens, R.J.H.G., M.M.P. van Oorschot en J. Ganzevles (2017). Bijdrage van Green Deals aan de beleidsdoelen voor natuur en biodiversiteit

95 Arets, E.J.M.M., J.W.H van der Kolk, G.M. Hengeveld, J.P. Lesschen, H. Kramer, P.J. Kuikman \& M.J. Schelhaas (2017). Greenhouse gas reporting for the LULUCF sector in the Netherlands. Methodological background, update 2017

96 IJsseldijk, L.L., M.J.L. Kik, L. Solé \& A. Gröne (2017). Postmortaal onderzoek van bruinvissen (Phocoena phocoena) uit Nederlandse wateren, 2016.

97 Verburg, R.W., W.H.G.J. Hennen, L.F. Puister, R. Michels \& K. van Duijvendijk (2017). Estimating costs of nature management in the European Union; Exploration modelling for PBL's Nature Outlook

98 Bruggen, C. van, A. Bannink, C.M. Groenestein, J.F.M. Huijsmans, H.H. Luesink, S.V. Oude Voshaar, S.M. van der Sluis, G.L. Velthof \& J. Vonk (2017). Emissies naar lucht uit de landbouw in 2015. Berekeningen met het model NEMA

99 Kuiters, A.T., G.A. de Groot, D.R. Lammertsma, H.A.H. Jansman \& J. Bovenschen (2017). Genetische monitoring van de Nederlandse otterpopulatie; Ontwikkeling van populatieomvang en genetische status 2016/2017

100 Adriaanse, P.I. \& W.H.J Beltman (2017) Comparison of pesticide concentrations at drinking water abstraction points in The Netherlands simulated by DROPLET version 1.2 and 2.0

101 Daamen, W.P., A.P.P.M. Clerkx \& M.J. Schelhaas (2017). Veldinstructie Zevende Nederlandse Bosinventarisatie (2017-2021).

102 Boer, T.A. de \& F.L. Langers (2017). Maatschappelijk draagvlak voor natuurbeleid en betrokkenheid bij natuur
103 Buijs, A.E., B.H.M. Elands \& C.S.A. van Koppen (2017) 25 jaar burgerbetrokkenheid in het natuurbeleid. Analyse van beleidsdiscoursen en publiek draagvlak

104 Cremer, J.S.M., S.M.J.M. Brasseur., A. Meijboom, J. Schop \& J.P. Verdaat (2017). Monitoring van gewone en grijze zeehonden in de Nederlandse Waddenzee, 2002-2017

105 Glorius, S.T., A. Meijboom, J.T. van der Wal \& J.S.M. Cremer (2017). Ontwikkeling van enkele mosselbanken in de Nederlandse Waddenzee, situatie 2016

106 Hennekens, S.M., W.A. Ozinga \& J.H.J. Schaminée (2017). BioScore 3 - Plants. Background and preprocessing of distribution data

107 Melman, Th.C.P., M.H.C. van Adrichem, M. Broekmeyer, J. Clement, R. Jochem, H.A.M. Meeuwsen, F.G.W.A. Ottburg, A.G.M. Schotman \& T. Visser (2017). Bijdrage natuurcombinaties aan landelijke natuurdoelstelling buiten NNN; Verkenning van een methodiek, gebaseerd op ecologische modellen

109 Overbeek, M.M.M., E. Smeets \& D. Verhoog (2017) Biobased materialen, circulaire economie en natuurlijk kapitaal. 




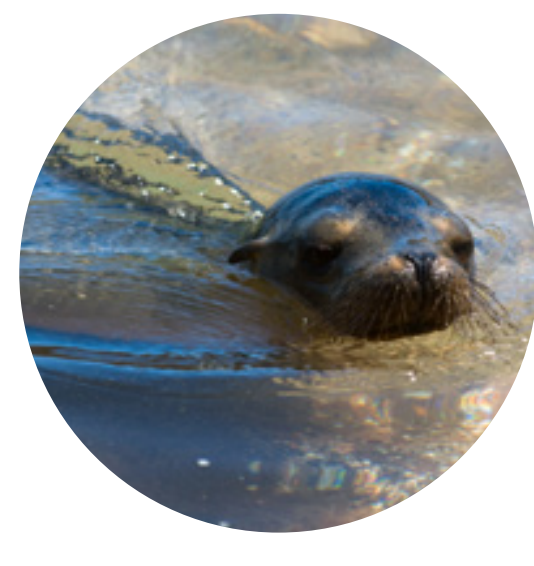

Thema Informatievoorziening Natuur Wettelijke Onderzoekstaken Natuur \& Milieu

Postbus 47

6700 AA Wageningen

T (0317) 485471

E info.wnm@wur.nl

ISSN 2352-2739

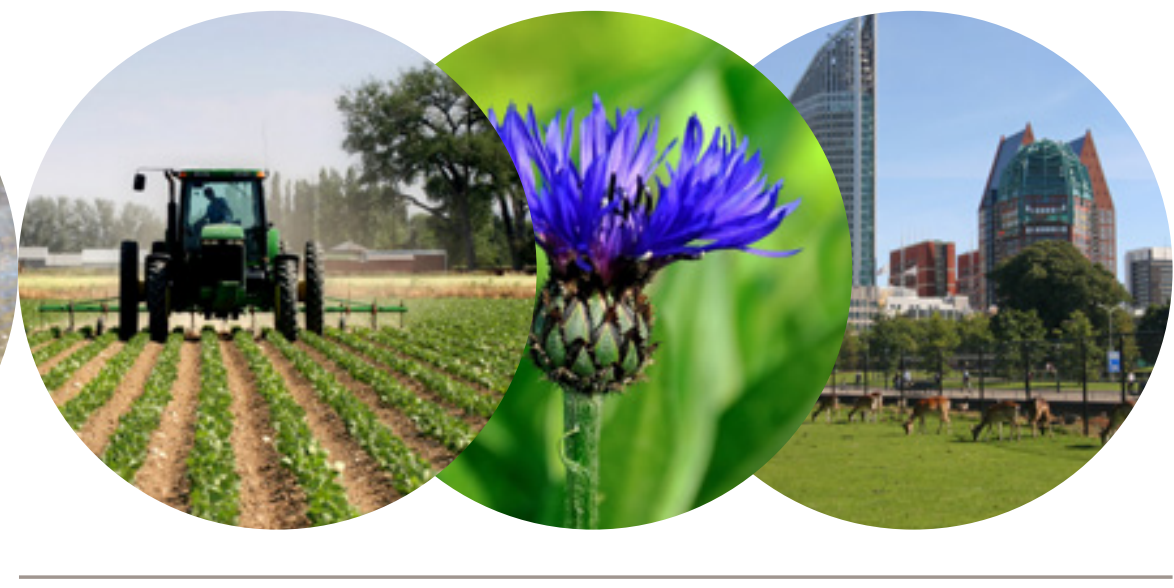

De missie van Wageningen University \& Research is 'To explore the potential of nature to improve the quality of life'. Binnen Wageningen University \& Research bundelen 9 gespecialiseerde onderzoeksinstituten van Stichting Wageningen Research en Wageningen University hun krachten om bij te dragen aan de oplossing van belangrijke vragen in het domein van gezonde voeding en leefomgeving. Met ongeveer 30 vestigingen, 5.000 medewerkers en 10.000 studenten behoort Wageningen University \& Research wereldwijd tot de aansprekende kennisinstellingen binnen haar domein. De integrale benadering van de vraagstukken en de samenwerking tussen verschillende disciplines vormen het hart van de unieke Wageningen aanpak. 